University of South Florida

DIGITAL COMMONS

@ UNIVERSITY OF SOUTH FLORIDA
Digital Commons @ University of

South Florida

$12-1-2012$

\title{
Implementing Transit Coordination in North Dakota Pilot Regions
}

CUTR

Follow this and additional works at: https://digitalcommons.usf.edu/cutr_nctr

\section{Recommended Citation}

"Implementing Transit Coordination in North Dakota Pilot Regions," National Center for Transit Research (NCTR) Report No. CUTR-NCTR-RR-2012-09, Center for Urban Transportation Research, University of South Florida, 2012.

DOI: https://doi.org/10.5038/CUTR-NCTR-RR-2012-09

Available at: https://scholarcommons.usf.edu/cutr_nctr/111

This Technical Report is brought to you for free and open access by the National Center for Transit Research (NCTR) Archive (2000-2020) at Digital Commons @ University of South Florida. It has been accepted for inclusion in Research Reports by an authorized administrator of Digital Commons @ University of South Florida. For more information, please contact digitalcommons@usf.edu. 


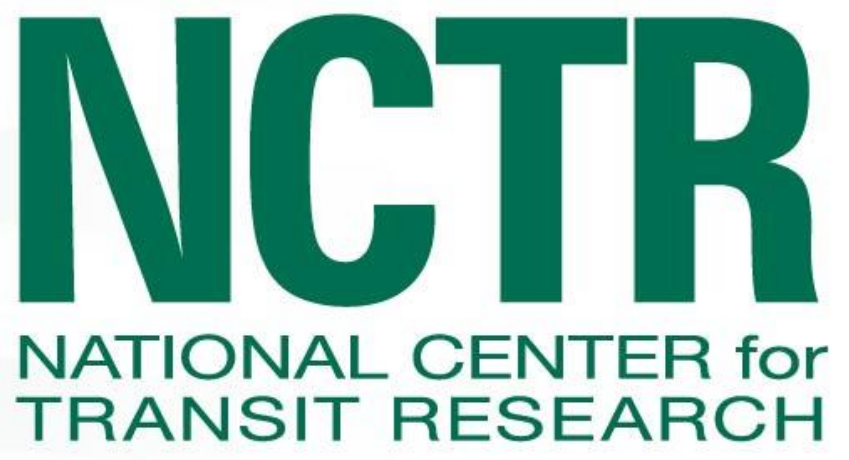

\section{Implementing Transit Coordination in North Dakota Pilot Regions}

Final Report

December 2012

PROJECT NO.

NDSU 2117-9050-02 A

PREPARED FOR

National Center for Transit Research (NCTR) 


\section{Disclaimer}

The contents of this report reflect the views of the authors, who are responsible for the facts and the accuracy of the information presented herein. This document is disseminated under the sponsorship of the Department of Transportation University Transportation Centers Program and the Florida Department of Transportation, in the interest of information exchange. The U.S. Government and the Florida Department of Transportation assume no liability for the contents or use thereof.

The opinions, findings, and conclusions expressed in this publication are those of the authors and not necessarily those of the State of Florida Department of Transportation. 


\title{
Implementing Transit Coordination in North Dakota Pilot Regions
}

\author{
Prepared for \\ North Dakota Department of Transportation \\ Prepared by \\ Jon Mielke, Associate Research Fellow \\ Keven Anderson, Associate Research Fellow \\ Carol Wright, Associate Director of Outreach and Training \\ Small Urban \& Rural Transit Center \\ a program of the \\ Upper Great Plains Transportation Institute \\ North Dakota State University \\ Fargo, North Dakota
}




\section{Metric Conversion}

\begin{tabular}{|c|c|c|c|c|}
\hline SYMBOL & WHEN YOU KNOW & MULTIPLY BY & TO FIND & SYMBOL \\
\hline \multicolumn{5}{|c|}{ LENGTH } \\
\hline in & inches & 25.4 & millimeters & $\mathrm{mm}$ \\
\hline ft. & feet & 0.305 & meters & $\mathrm{m}$ \\
\hline yd. & yards & 0.914 & meters & $\mathrm{m}$ \\
\hline mi & miles & 1.61 & kilometers & $\mathrm{km}$ \\
\hline \multicolumn{5}{|c|}{ VOLUME } \\
\hline fl. oz. & fluid ounces & 29.57 & milliliters & $\mathrm{mL}$ \\
\hline gal & gallons & 3.785 & liters & $\mathrm{L}$ \\
\hline $\mathbf{f t}^{3}$ & cubic feet & 0.028 & cubic meters & $\mathrm{m}^{3}$ \\
\hline$y^{d^{3}}$ & cubic yards & 0.765 & cubic meters & $\mathrm{m}^{3}$ \\
\hline \multicolumn{5}{|c|}{ NOTE: volumes greater than $1000 \mathrm{~L}$ shall be shown in $\mathrm{m}^{3}$} \\
\hline \multicolumn{5}{|c|}{ MASS } \\
\hline oz. & ounces & 28.35 & grams & $\mathrm{g}$ \\
\hline lb. & pounds & 0.454 & kilograms & $\mathrm{kg}$ \\
\hline $\mathbf{T}$ & Short tons (2000 lb.) & 0.907 & $\begin{array}{c}\text { megagrams } \\
\text { (or "metric ton") }\end{array}$ & $\mathrm{Mg}$ (or "t") \\
\hline \multicolumn{5}{|c|}{ TEMPERATURE (exact degrees) } \\
\hline${ }^{\mathbf{o}} \mathbf{F}$ & Fahrenheit & $\begin{array}{c}5(\mathrm{~F}-32) / 9 \\
\text { or }(\mathrm{F}-32) / 1.8\end{array}$ & Celsius & ${ }^{\circ} \mathrm{C}$ \\
\hline
\end{tabular}




\section{Technical Report Documentation}

\begin{tabular}{|c|c|c|c|}
\hline $\begin{array}{l}\text { 1. Report No. } \\
\text { NDSU 2117-9050-02 A }\end{array}$ & \multicolumn{2}{|c|}{ 2. Government Accession No. } & 3. Recipient's Catalog No. \\
\hline \multicolumn{2}{|l|}{ 4. Title and Subtitle } & \multicolumn{2}{|c|}{ December 2012} \\
\hline \multicolumn{4}{|c|}{ 6. Performing Organization Code } \\
\hline \multicolumn{2}{|c|}{$\begin{array}{l}\text { 7. Author(s) } \\
\text { Small Urban \& Rural Transit Center } \\
\text { Upper Great Plains Transportation Institute } \\
\text { North Dakota State University } \\
\text { Fargo, North Dakota }\end{array}$} & \multicolumn{2}{|c|}{ 8. Performing Organization Report No. } \\
\hline \multicolumn{2}{|c|}{$\begin{array}{l}\text { 9. Performing Organization Name and Address } \\
\text { National Center for Transit Research } \\
\text { Center for Urban Transportation Research (CUTR) } \\
\text { University of South Florida } \\
\text { 4202 East Fowler Avenue, CUT100 } \\
\text { Tampa, FL 33620-5375 }\end{array}$} & \multicolumn{2}{|c|}{ 10. Work Unit No. (TRAIS) } \\
\hline \multicolumn{4}{|l|}{ 11. Contract or Grant No. } \\
\hline \multicolumn{2}{|c|}{$\begin{array}{l}\text { 12. Sponsoring Agency Name and Address } \\
\text { Research and Innovative Technology Administration } \\
\text { U.S. Department of Transportation } \\
\text { Mail Code RDT-30, } 1200 \text { New Jersey Ave SE, Room E33 } \\
\text { Washington, DC 20590-0001 }\end{array}$} & \multicolumn{2}{|c|}{ 13. Type of Report and Period Covered } \\
\hline \multicolumn{4}{|c|}{ 14. Sponsoring Agency Code } \\
\hline \multicolumn{4}{|l|}{ 15. Supplementary Notes } \\
\hline \multicolumn{4}{|l|}{ 16. Abstract } \\
\hline \multicolumn{2}{|l|}{ 17. Key Words } & \multicolumn{2}{|c|}{$\begin{array}{l}\text { 18. Distribution Statement } \\
\text { No restrictions }\end{array}$} \\
\hline $\begin{array}{l}\text { 19. Security Classification } \\
\text { (of this report) } \\
\text { Unclassified }\end{array}$ & $\begin{array}{l}\text { 20. Security Classification } \\
\text { (of this page) } \\
\text { Unclassified }\end{array}$ & $\begin{array}{l}21 . \mathrm{N} \\
140\end{array}$ & 22. Price \\
\hline
\end{tabular}




\section{TABLE OF CONTENTS}

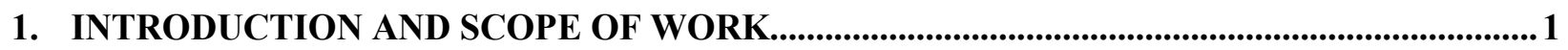

2. EXISTING SERVICES, CURRENT COORDINATION ACTIVITIES, ROUTE AND FARE COMPARISONS, AND NDDOT TRANSIT STAFFING ................................................5

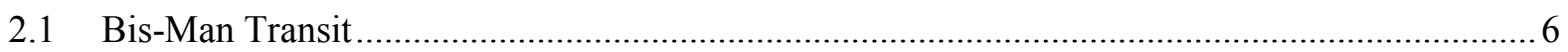

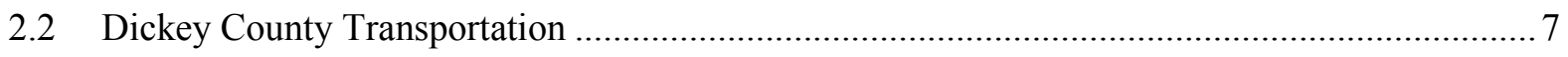

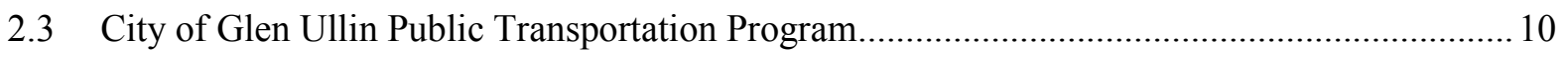

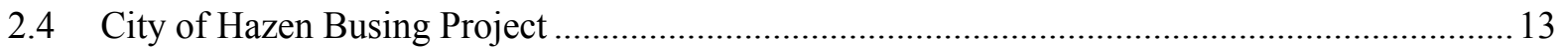

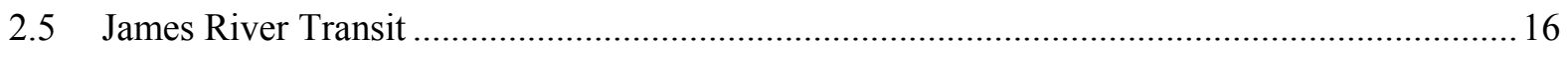

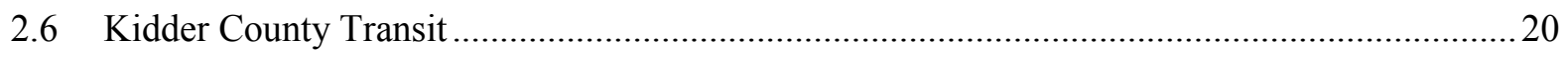

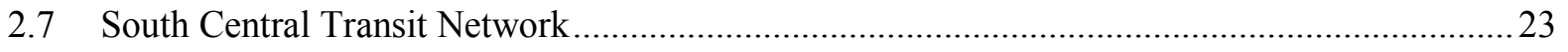

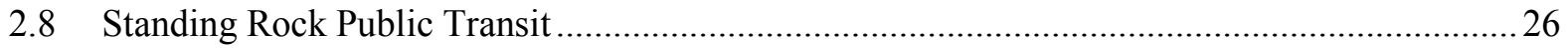

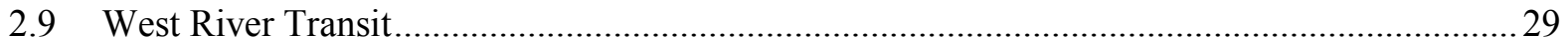

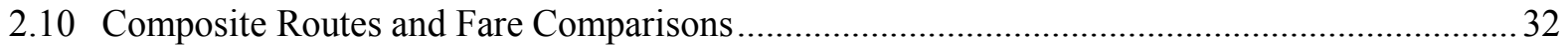

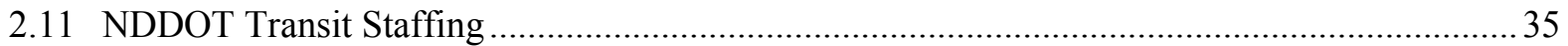

3. PROJECT TASKS, ACHIEVEMENTS, AND ONGOING ACTIVITIES...................................37

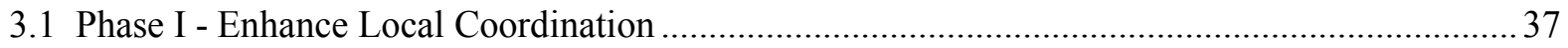

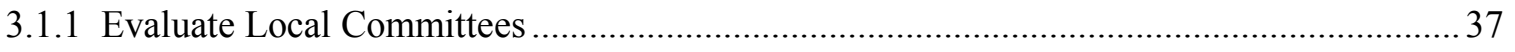

3.1.2 Establish/Reconfigure Local Advisory Committees....................................................... 38

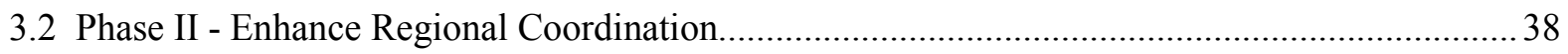

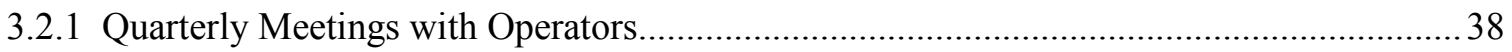

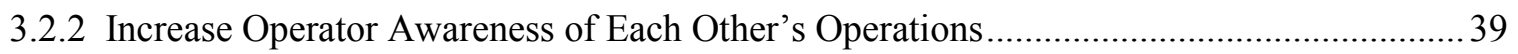

3.2.3 Seek Uniformity in Operator Policies, Services, and Practices ....................................... 39

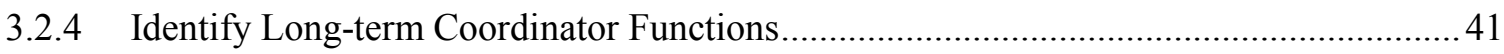

3.3 Phase III - Increase Public Awareness of Available Services .................................................. 42

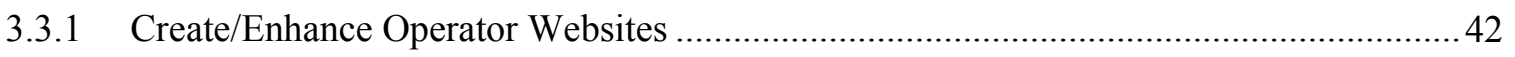

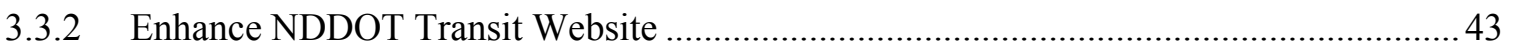

3.3.3 Create Additional Mechanisms to Publicize Transit Services .......................................... 44

3.4 Phase IV - Monitor Performance, Establish Uniform Standards, Develop Coordination Budgets, and Work with Mobility Managers to Facilitate Further Coordination........................ 44

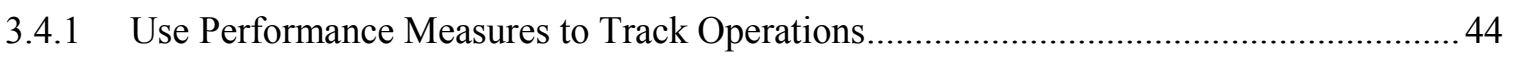

3.4.2 Establish Uniform Operating Standards and Policies ................................................... 45

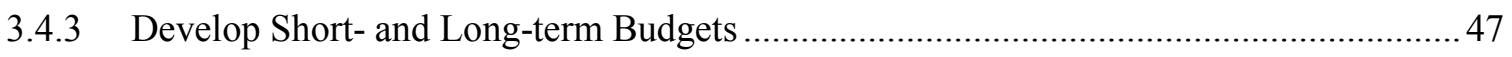


3.4.4 Work with Mobility Managers to Facilitate Coordination............................................. 47

3.4.5 Hold Semi-monthly Progress Meetings with NDDOT's Transit Staff ........................... 49

3.4.6 Document Coordination-related Achievements............................................................ 49

3.5 Phase V - Prepare and Present Coordination Implementation Report ...................................... 52

3.5.1 Prepare Coordination Implementation Report .............................................................. 52

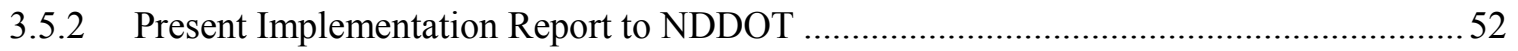

\section{RECOMMENDATIONS FOR FURTHER COORDINATION AND CORRESPONDING}

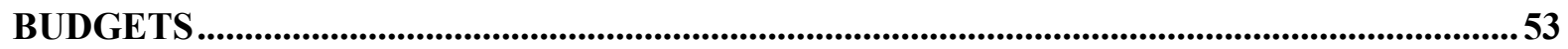

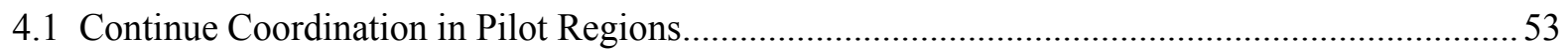

4.1.1 Regional Transit Coordinator Positions and Locations - Pilot Regions ..............................53

4.1.2 Regional Transit Coordinator Qualifications and Job Functions - Pilot Regions ................54

4.1.3 Budgets and Funding Sources - Pilot Regions ….............................................................. 56

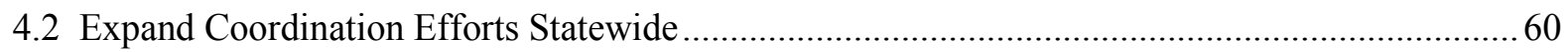

4.2.1 Number of Coordination Regions and Coordinators - Statewide Coverage .......................60

4.2.2 Regional Coordinator Qualifications and Job Functions - Statewide Coverage .................63

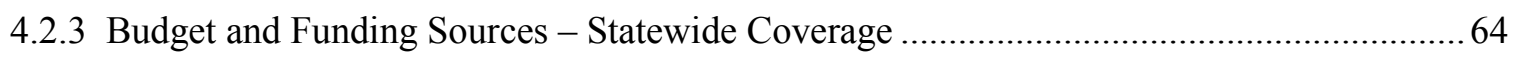

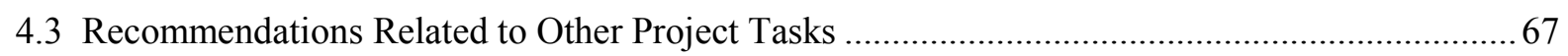

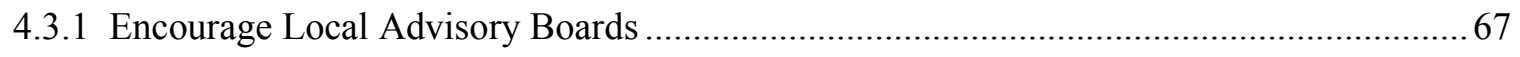

4.3.2 Continue Quarterly Meetings and Promote Operator Awareness ....................................... 68

4.3.3 Promote Increased Uniformity - Policies, Services, Practices, and Fares............................ 68

4.3.4 Establish/Update and Maintain Local Websites ................................................................. 69

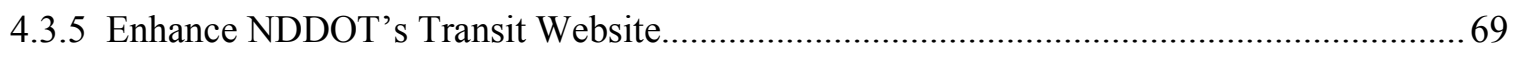

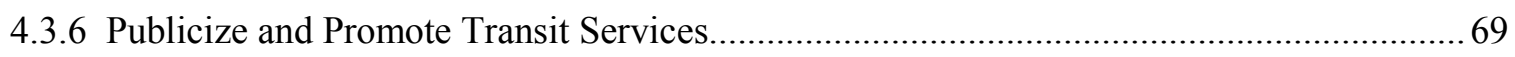

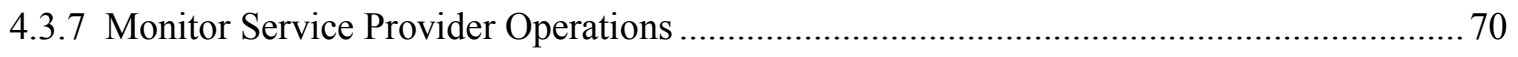

4.3.8 Document Coordination-related Achievements and Benefits............................................ 70

4.3.9 Monitor Operators' Implementation of Service Modifications .......................................... 70

APPENDIX A: Advisory Board Guidelines and Template Bylaws..........................................................71

APPENDIX B: Transit Coordination Self-Assessments............................................................................. 77

APPENDIX C: Template Riders' Guide .................................................................................................... 103

APPENDIX D: Operator Input Concerning Coordination Project and Future Efforts .................. 109

APPENDIX E: Service Reliability Guidelines and Template Policy...................................................... 121

APPENDIX F：Guidelines on Shared Transit Vehicles...................................................................... 125 


\section{LIST OF TABLES}

Table 2.1 Dickey County Transportation - Financial, Operating, and Performance Trends.................... 9

Table 2.2 Glen Ullin Public Transportation - Financial, Operating, and Performance Trends ............... 12

Table 2.3 Hazen Busing - Financial, Operating, and Performance Trends ........................................... 15

Table 2.4 James River Transit - Financial, Operating, and Performance Trends ................................. 19

Table 2.5 Kidder County Transit - Financial, Operating, and Performance Trends ............................. 22

Table 2.6 South Central Transit Network - Financial, Operating, and Performance Trends ..................26

Table 2.7 Standing Rock Public Transportation - Financial, Operating, and Performance Trends ......... 29

Table 2.8 West River Transit - Financial, Operating, and Performance Trends ................................... 32

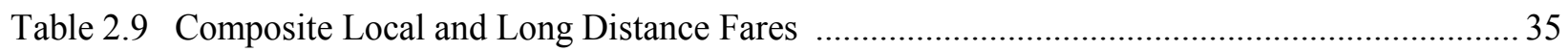

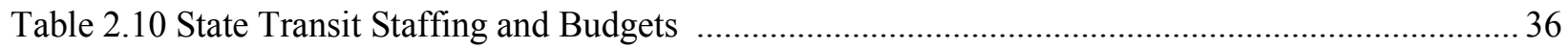

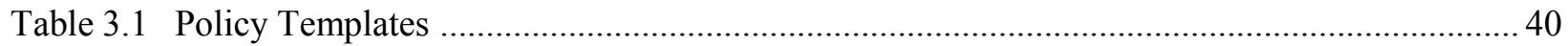

Table 3.2 Measures of Service Reliability and Operational Impacts of Coordination ........................... 46

Table 4.1 Regional Transit Coordination Budgets - Pilot Regions ...................................................... 57

Table 4.2 Federal Transit Funding - North Dakota Appropriations (2010-2012) ................................... 58

Table 4.3 MAP-21 - North Dakota FY 2013 Appropriations ............................................................. 59

Table 4.4 Transit Regions - Counties, Rural Transit Operators, and Urban Centers ............................. 62

Table 4.5 Existing and Proposed Regional Transit Coordinators - Statewide Coverage .......................63

Table 4.6 Regional Transit Coordination Budget - Four Coordinators Providing Statewide Coverage .. 65

Table 4.7 Regional Transit Coordination Budget - Five Coordinators Providing Statewide Coverage... 66 


\section{LIST OF FIGURES}

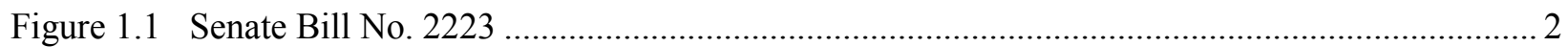

Figure 1.2 South Central and West Central Pilot Regions................................................................... 3

Figure 1.3 Scope of Work - Projects Phases, Tasks, and Timeline ......................................................... 4

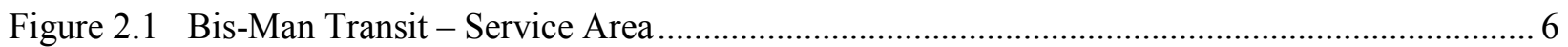

Figure 2.2 Dickey County Transportation - Service Area …............................................................ 7

Figure 2.3 Dickey County Transportation - Routes to Regional Centers .............................................. 8

Figure 2.4 Glen Ullin Public Transportation - Service Area................................................................. 10

Figure 2.5 Glen Ullin Public Transportation - Routes to Regional Centers......................................... 11

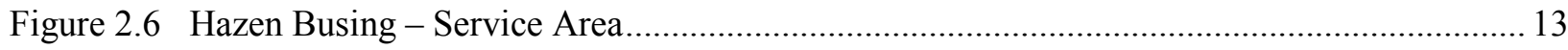

Figure 2.7 Hazen Busing - Routes to Regional Centers.................................................................. 14

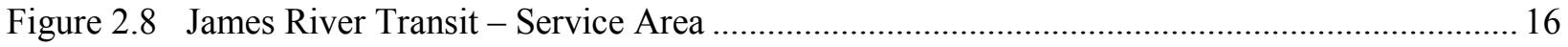

Figure 2.9 James River Transit - Routes to Regional Centers ........................................................ 17

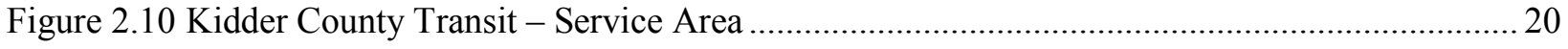

Figure 2.11 Kidder County Transit - Routes to Regional Centers ..................................................... 21

Figure 2.12 South Central Transit Network - Service Area ................................................................ 23

Figure 2.13 South Central Transit Network - Routes to Regional Centers ............................................. 24

Figure 2.14 Standing Rock Public Transportation - North Dakota Service Area ................................... 27

Figure 2.15 Standing Rock Public Transportation - Routes to Regional Centers ................................... 28

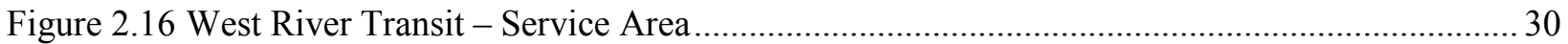

Figure 2.17 West River Transit - Routes to Regional Centers ............................................................... 31

Figure 2.18 South Central Region - Routes to Regional Centers.......................................................... 33

Figure 2.19 West Central Region - Routes to Regional Centers........................................................... 34

Figure 4.1 Regional Transit Coordinator Qualifications and Job Duties - Pilot Regions ....................... 55

Figure 4.2 Potential Transit Coordination Regions - Statewide Coverage ........................................... 61 


\section{Acknowledgments}

This research was funded by the North Dakota Department of Transportation. It was conducted by the Small Urban \& Rural Transit Center, a program of the Upper Great Plains Transportation Institute at North Dakota State University.

The authors acknowledge the guidance provided by Paul Benning, Stacey Hanson, Kim Adair, and Becky Hanson of the North Dakota Department of Transportation and the involvement and input provided by the managers of the eight rural transit programs in North Dakota's south central and west central regions. 


\section{EXECUTIVE SUMMARY}

Senate Bill No. 2223, as enacted by the 2009 North Dakota Legislature, directed that the North Dakota Department of Transportation (NDDOT) develop two public transportation coordination pilot projects in the state. Corresponding goals included more cost-effective and efficient transit services, reduced fragmentation and duplication, more uniform operating standards, and enhanced personal mobility. Senate Bill No. 2223 compliments federal mandates regarding the coordination of transit services.

NDDOT subsequently contracted the Small Urban \& Rural Transit Center (SURTC) to study existing services and to prepare findings and recommendations concerning enhanced coordination in the selected south central and west central pilot regions. NDDOT forwarded the resulting report and recommendations to the Legislative Council in January 2011.

In October 2011, NDDOT executed a second contract with SURTC to pursue implementation of recommendations contained in the prior report. The project's work plan included 17 tasks that focused on increased local input regarding existing and evolving mobility needs, increased coordination among the regions' operators, more uniform operating standards and policies, and short- and long-term budgets for continued and expanded coordination.

The regions' transit managers were heavily involved with related work. These managers were asked to complete a coordination self-assessment, which helped identify opportunities for increased coordination. Composite route maps and fare structures were developed to identify prospects for consolidating routes, increasing mobility options for area residents, and moving toward more standardized fares. Related meetings were held with various subsets of operators, and plans were made regarding service modifications that would increase both operating efficiencies and personal mobility.

To help promote the availability of local transit services, SURTC worked with NDDOT's transit staff and local operators to establish or upgrade local transit websites. Seven of the regions' eight local operators took advantage of this promotional opportunity. A concurrent effort was made to enhance NDDOT's transit website. Efforts were also made to create a library of materials related to local and statewide promotional efforts and policies that reflect industry best practices.

SURTC researchers also worked with NDDOT's Transit Section to develop guidelines that should increase uniformity and service reliability within the state's transit industry. Mechanisms were also developed to help NDDOT's Transit Section monitor the long-term impacts of coordination.

Concurrent with the work on this project, NDDOT's Transit Section contracted with North Dakota Community Action and Bis-Man Transit to hire regional transit coordinators for the south central and west central pilot regions. This action was consistent with the provision of Senate Bill No. 2223, which states that each pilot region must have a regional coordination administrator. SURTC worked with NDDOT's transit staff to develop corresponding multi-year budgets for these positions. It is estimated that each of these positions will require up to $\$ 76,000$ per year in federal funds. This total includes salaries and benefits, travel, and office-related expenses.

It is anticipated that these coordinators will eventually be capable of overseeing coordination-related activities in more than the initial pilot regions. It is also assumed that the Legislature envisioned that enhanced coordination would be beneficial and cost-effective, and that it would ultimately be expanded to the entire state. 
During the course of this project, NDDOT's Transit Section contracted with Cities Area Transit of Grand Forks to provide regional coordination services in the northeast quadrant of the state. A coordinator position also already exists in the Fargo-West Fargo-Moorhead urban area.

Given these expectations and related actions, this project developed a phased implementation plan and related budgets to accomplish statewide coordination. As the following map illustrates, the plan divides the state into several coordination regions. Initial coverage is being provided in the two pilot regions (B-1 and $\mathrm{C}-1$ ), in the northeast region (A-1), and in the Fargo urban area.

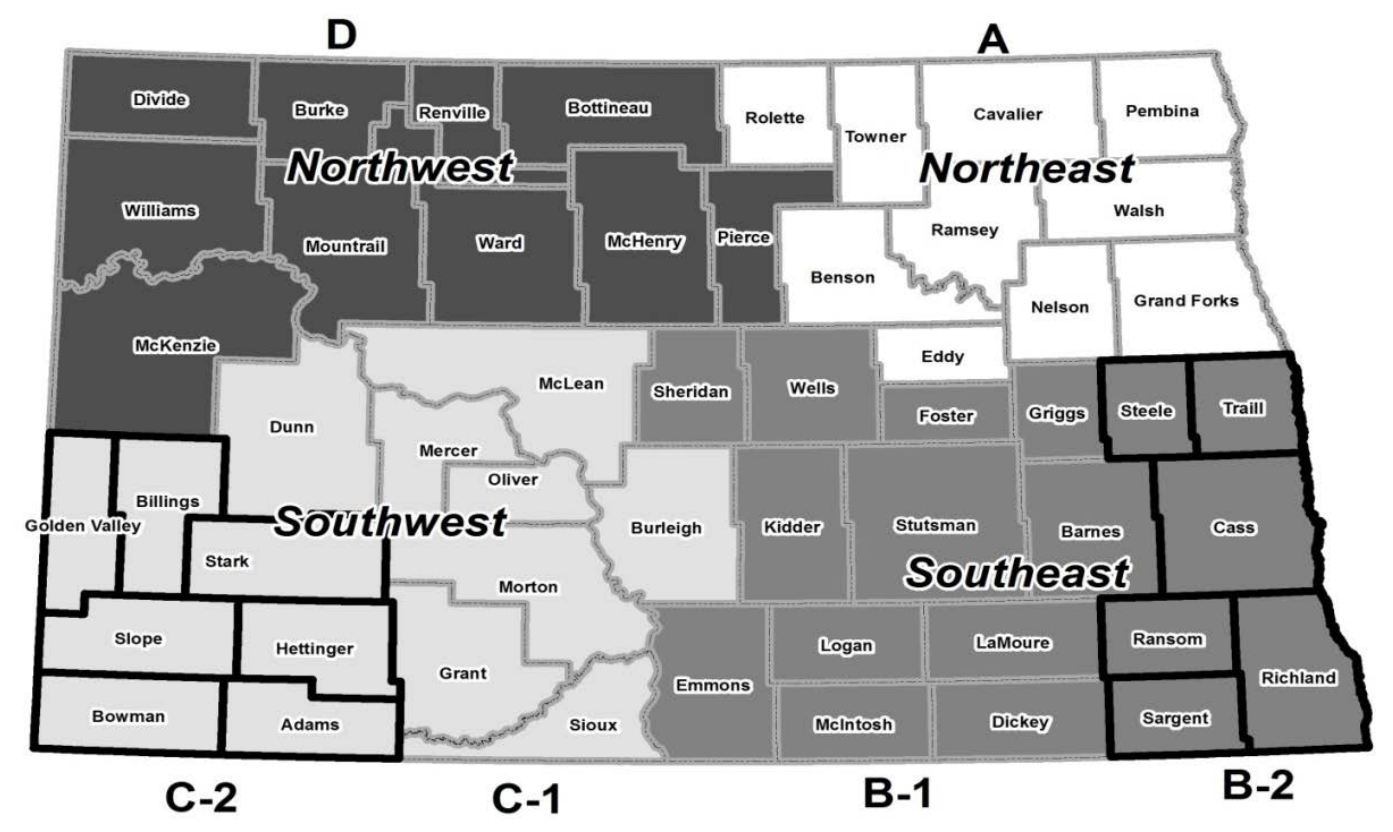

Potential Transit Coordination Regions - Statewide Coverage

It is anticipated that within two years, the coordinators assigned to the two pilot regions will be able to assume expanded roles encompassing all of the southeast and southwest quadrants of the state.

Continuing discussions will need to take place with Fargo area transit officials to determine if the urban area's transit coordinator is able to assume additional responsibilities involving the entire southeast portion of the state. If so, the coordinator of the south central pilot region could be reassigned to the northwest region. If not, an additional position would need to be created to coordinate transit services in that region.

It appears, therefore, that statewide transit coordination will eventually require either four or five regional transit coordinators. It is also possible that statewide coverage can be achieved with fewer regional coordinators. Assessments regarding the appropriated number of coordinators will need to be made as the overall implementation process continues.

NDDOT already has contracts in place for coordinators in the south central and west central pilot regions, the northeast region, and the Fargo urban area. Achieving statewide coverage will, therefore, require no more than one additional position. The federal share of the four existing positions, including salaries, travel, and office-related expenses, is approximately $\$ 280,000$ per year. Optimal coverage can be accomplished with five coordinators, one for each region of the state and one for the Fargo urban area. Given the availability of additional federal funds and cost sharing with the state of Minnesota for the 
Fargo position, the incremental cost of a five- vs. four-coordinator scenario is estimated at $\$ 35,000$ in federal funds.

It is projected that statewide coverage can be accomplished within four years, and that it can be undertaken with currently appropriated federal funding that will cover $80 \%$ of associated costs. The remaining $20 \%$ of related costs would need to come from local sources. NDDOT also has the option of funding related efforts with federal administrative funds that require no local match. Doing so would, however, reduce the amount of money that is available to fund transit services in rural areas.

The value of enhanced coordination has been demonstrated by this project's documented accomplishments. Given these facts, related federal mandates, and the availability of funding, transit coordination efforts should be continued in the prescribed pilot regions and eventually expanded to encompass the entire state. Doing so will increase overall operating efficiencies and enhance personal mobility for state residents and guests.

Draft copies of the report were sent to transit managers in the two pilot regions on November 1,2012, and to the state's other transit managers on November 13, 2013. Three mangers provided written comments. Their input is presented in the final pages of Appendix D of the report. No comments were received from the state's other 29 transit managers. 



\section{INTRODUCTION AND SCOPE OF WORK}

This project was designed to facilitate further regional transit coordination in North Dakota as mandated by the 2009 Legislature when it enacted Senate Bill No. 2223, a copy of which is presented in Figure 1.1. The intent of the bill was to coordinate the provision of public transportation services, reduce fragmentation and duplication, and increase effectiveness and efficiency.

The bill directed the North Dakota Department of Transportation (NDDOT) to develop coordination pilot projects in two regions of the state. One region was to have a city with a population of over 35,000 , and one was to have no city with a population of 35,000 or more. The department subsequently chose the south central and west central regions to serve as the focus of related coordination efforts. These regions are identified in Figure 1.2.

NDDOT subsequently contracted with the Small Urban \& Rural Transit Center (SURTC) to study various coordination options and to develop corresponding recommendations. The resulting report was completed in December 2010. NDDOT presented it to the Legislative Council in January 2011.

In October 2011, NDDOT contracted with SURTC to work toward the implementation of 17 coordination-related tasks in the two pilot regions and to develop corresponding recommendations and short- and long-term budgets for subsequent work. These tasks and related timelines are summarized in Figure 1.3. As this figure illustrates, the entire project was to be completed by the end of 2012. Work on most of the tasks was to be ongoing and simultaneous.

As the map in Figure 1.2 indicates, the south central region encompassed 12 counties and the west central region included 8 counties. Each region had four rural transit operators. Some of the related service areas were single cities or counties while others were large, multi-county areas. All of these operators were heavily involved in the study process and provided considerable information regarding their existing services, routes, fares, policies, and operating practices. Their input is reflected in subsequent chapters and served as the basis for many of the recommendations that are presented in the final chapter of this report.

In addition to personal visits and frequent telephone and electronic communications between SUTRC researchers and individual transit managers, quarterly meetings were also held to solicit information from operators to keep them updated on ongoing activities and to provide an educational, information-sharing forum involving all of the regions' rural transit mangers. Participants in these meetings included transit managers, SURTC researchers, and staff members of NDDOT's Transit Section.

SURTC staff members and NDDOT transit staff also held semi-monthly status report meetings throughout the course of this project. These meetings were invaluable and provided a mechanism that facilitated the constant flow of information between the parties and provided ongoing direction that kept the project on schedule.

SURTC provided NDDOT's Transit Section with a draft copy of each chapter of the report as it was completed. This process permitted an ongoing review of related work products and contributed to the accuracy and timely completion of the final report. Chapters regarding existing transit services and project tasks and related achievements were also shared with the regions' transit managers as they were completed, and corresponding corrections were made based on input received.

Draft copies of the full report were sent to transit managers in the two pilot regions on November 1, 2012, and to the state's other transit managers on November 13, 2013. Three managers provided written 
comments. Their input is presented in the final pages of Appendix D of the report. No comments were received from the state's other 29 transit managers.

Including this introductory chapter, this report contains four chapters and five appendices. The remaining chapters describe the regions' existing transit service and current coordination activities, project tasks and related achievements, and recommendations for further coordination.

It is assumed that the Legislature hoped that work in the pilot regions would prove successful and might lead to related coordination activities across the state. As Chapter 3 will indicate, this project's coordination efforts have, in fact, been successful and warrant emulation elsewhere in the state. The final chapter of this report does, therefore, include recommendations and corresponding short- and long-term budget projections regarding coordination in not only the two pilot regions, but also throughout the state.

\title{
Sixty-first Legislative Assembly of North Dakota In Regular Session Commencing Tuesday, January 6, 2009
}

\author{
SENATE BILL NO. 2223 \\ (Senators Robinson, Nething) \\ (Representatives Delmore, R. Kelsch, Weisz)
}

AN ACT to provide for regional public transportation pilot projects; and to provide for a report to the legislative assembly.

\section{BE IT ENACTED BY THE LEGISLATIVE ASSEMBLY OF NORTH DAKOTA:}

\section{SECTION 1. REGIONAL PUBLIC TRANSPORTATION COORDINATION PILOT}

PROJECTS -- SPENDING AUTHORITY. The department of transportation shall develop two public transportation coordination pilot projects in two of this state's planning regions. One project must focus on coordination in a region that does not have a city with a population over thirty-five thousand and one project must focus on coordination in a region that has a city with a population exceeding thirty-five thousand. The department shall implement one project in 2009 and one project in 2010. Each pilot project must have a regional coordination administrator who coordinates the provision of public transportation services to the residents of the region in a manner that is costeffective, efficient, and reduces fragmentation and duplication of services. The regional coordination administrator shall assist communities in public transportation planning in the specified region to develop a structure that will support a coordinated public transportation system. The department shall develop standards for public transportation providers and contractors who provide public transportation within the coordinated public transportation system. These standards must promote coordination among public transportation providers. The department may spend additional funds from gifts, grants, or donations and those additional funds are appropriated for the purposes of this section.

SECTION 2. REPORT TO LEGISLATIVE ASSEMBLY. The director of the department of transportation shall report to the sixty-second legislative assembly with findings and recommendations based on the results of the public transportation coordination pilot projects.

Figure 1.1 Senate Bill No. 2223 


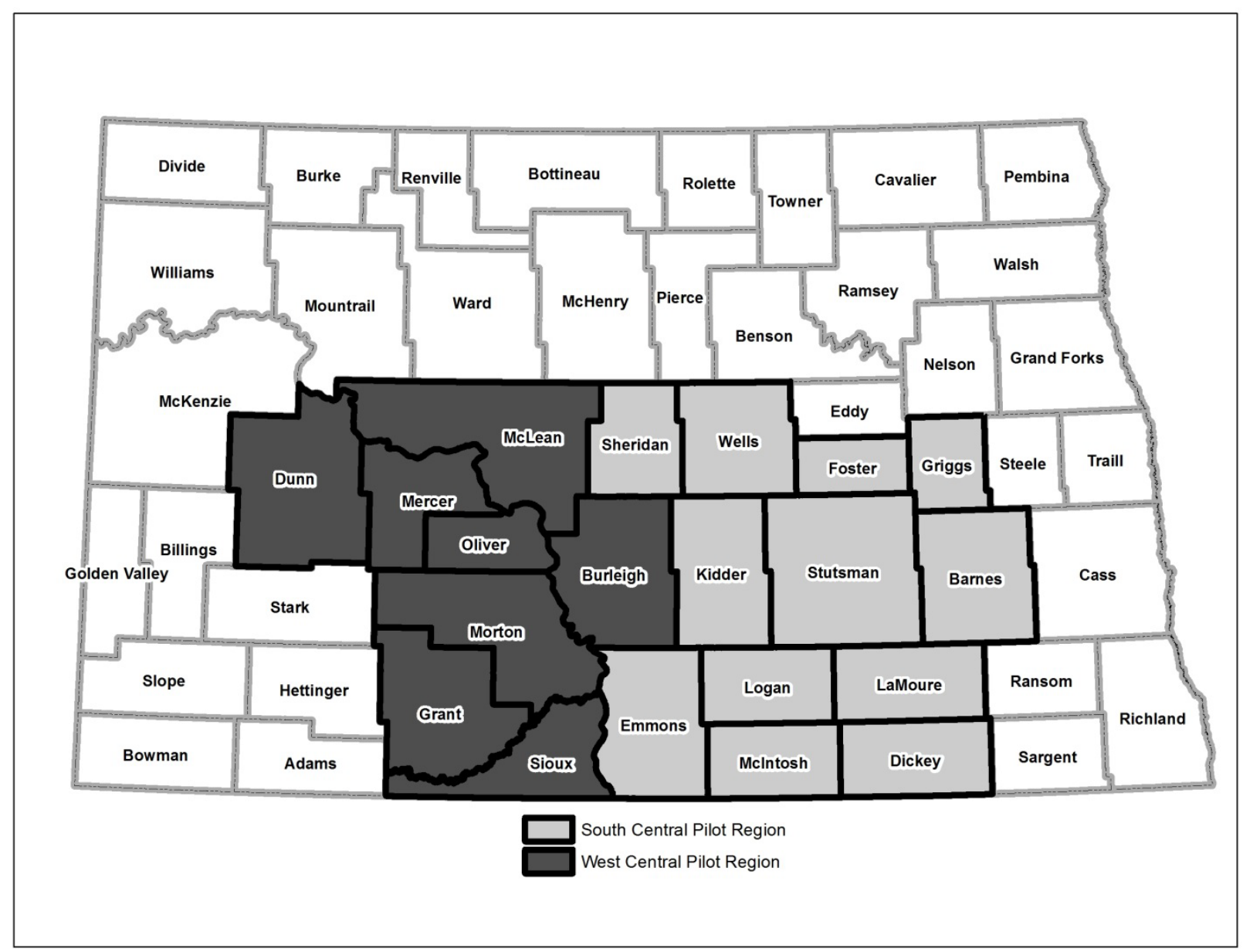

Figure 1.2 South Central and West Central Pilot Regions 


\begin{tabular}{|c|c|c|c|c|c|}
\hline Task & $\begin{array}{c}4^{\text {th }} \\
\text { Quarter } \\
2011\end{array}$ & $\begin{array}{c}1^{\text {st }} \\
\text { Quarter } \\
2012\end{array}$ & $\begin{array}{c}2^{\text {nd }} \\
\text { Quarter } \\
2012\end{array}$ & $\begin{array}{c}\mathbf{3}^{\text {rd }} \\
\text { Quarter } \\
2012\end{array}$ & $\begin{array}{c}4^{\text {th }} \\
\text { Quarter } \\
2012\end{array}$ \\
\hline \multicolumn{6}{|l|}{ Phase I } \\
\hline Task I-1 Evaluate local committees & $\checkmark$ & & & & \\
\hline Task I-2 Reconfigure local committees & & $\checkmark$ & $\checkmark$ & & \\
\hline \multicolumn{6}{|l|}{ Phase II } \\
\hline $\begin{array}{l}\text { Task II-1 Quarterly meetings with } \\
\text { operators }\end{array}$ & $\checkmark$ & $\checkmark$ & $\checkmark$ & $\checkmark$ & \\
\hline $\begin{array}{l}\text { Task II-2 Create operator awareness of } \\
\text { each other's operations }\end{array}$ & $\checkmark$ & $\checkmark$ & $\checkmark$ & $\checkmark$ & \\
\hline $\begin{array}{l}\text { Task II-3 Seek uniformity in policies, } \\
\text { fare recovery, etc. }\end{array}$ & $\checkmark$ & $\checkmark$ & $\checkmark$ & $\checkmark$ & \\
\hline $\begin{array}{l}\text { Task II-4 Identify long-term coordinator } \\
\text { functions \& funding sources }\end{array}$ & $\checkmark$ & $\checkmark$ & $\checkmark$ & $\checkmark$ & \\
\hline \multicolumn{6}{|l|}{ Phase III } \\
\hline $\begin{array}{l}\text { Task III-1 Create/enhance operator } \\
\text { websites }\end{array}$ & $\checkmark$ & $\checkmark$ & $\checkmark$ & $\checkmark$ & \\
\hline $\begin{array}{l}\text { Task III-2 Create/enhance NDDOT } \\
\text { website on transit services }\end{array}$ & $\checkmark$ & $\checkmark$ & $\checkmark$ & $\checkmark$ & \\
\hline $\begin{array}{l}\text { Task III-3 Create additional mechanisms } \\
\text { to publicize transit services }\end{array}$ & $\checkmark$ & $\checkmark$ & $\checkmark$ & $\checkmark$ & \\
\hline \multicolumn{6}{|l|}{ Phase IV } \\
\hline $\begin{array}{l}\text { Task IV-1 Use performance measures to } \\
\text { track operations }\end{array}$ & & $\checkmark$ & $\checkmark$ & $\checkmark$ & \\
\hline $\begin{array}{l}\text { Task IV-2 Establish uniform operating } \\
\text { standards \& policies }\end{array}$ & $\checkmark$ & $\checkmark$ & $\checkmark$ & $\checkmark$ & \\
\hline $\begin{array}{l}\text { Task IV-3 Develop short- \& long-term } \\
\text { budgets }\end{array}$ & & & $\checkmark$ & $\checkmark$ & \\
\hline $\begin{array}{l}\text { Task IV-4 Work with mobility managers } \\
\text { to facilitate coordination }\end{array}$ & $\checkmark$ & $\checkmark$ & $\checkmark$ & $\checkmark$ & \\
\hline $\begin{array}{l}\text { Task IV-5 Hold semi-monthly progress } \\
\text { meetings with NDDOT }\end{array}$ & $\checkmark$ & $\checkmark$ & $\checkmark$ & $\checkmark$ & $\checkmark$ \\
\hline $\begin{array}{l}\text { Task IV-6 Document coordination- } \\
\text { related achievements }\end{array}$ & $\checkmark$ & $\checkmark$ & $\checkmark$ & $\checkmark$ & $\checkmark$ \\
\hline \multicolumn{6}{|l|}{ Phase V } \\
\hline $\begin{array}{l}\text { Task V-1 Prepare coordination } \\
\text { implementation report }\end{array}$ & & & & $\checkmark$ & $\checkmark$ \\
\hline $\begin{array}{l}\text { Task V-2 Present implementation report } \\
\text { to NDDOT }\end{array}$ & & & & & $\checkmark$ \\
\hline
\end{tabular}

Figure 1.3 Scope of Work - Project Phases, Tasks, and Timeline 


\section{EXISTING SERVICES, CURRENT COORDINATION ACTIVITIES, ROUTE AND FARE COMPARISONS, AND NDDOT TRANSIT STAFFING}

There are nine transit service providers in the 19 counties that comprise North Dakota's west central and south central regions. Bis-Man Transit serves the Bismarck-Mandan metropolitan area while the other eight operators provide local services in the regions' other cities and service from these cities and rural areas into regional centers including Fargo, Bismarck, Dickinson, Minot, and Aberdeen (SD).

The regions' transit agencies are a heterogeneous group. Some systems provide strictly transit services while others are multi-service providers that operate senior citizen centers, provide local meal services, etc. Some are government-run, while others are private, nonprofit organizations. Some operate very small fleets and serve only one community, while others have dozens of vehicles and serve large, multicounty areas.

This chapter updates transit agency profiles that were previously presented in SURTC's 2010 coordination report. Information is presented concerning each operator's services, service area, routes, fares, and existing coordination activities. Information related to existing coordination efforts and opportunities for increased coordination is based largely on coordination self-assessments that were completed by the director of each of the pilot region's eight rural transit services as a part of this project's scope of work. Related statements are reflective of transit operations as they existed as of June 2012. Subsequent changes will be discussed in later chapters of this report.

In addition to agency profiles and current coordination activities, this chapter also presents and analyzes performance data regarding each agency's operations. Traditional performance measures include oneway passenger trips; annual vehicle revenue miles and vehicle revenue hours; operating expense per hour, per mile, and per one-way trip; one-way trips per revenue hour; and one-way trips per service area population.

An ongoing review of performance-related data helps agencies measure operating efficiencies and service effectiveness. When measured over time, it allows agency personnel and advisory boards to track and evaluate their transit operations and improve decision making on both a day-to-day and long-term basis.

Composite route information and fare comparisons will be presented in Section 2.10. Related route information will be used to help identify situations where reconfigurations might be possible to reduce service overlaps and increase overall efficiency. Related savings might also be used to increase service offerings in other areas. Fare comparison presentations will be used to identify significant discrepancies and may eventually lead to more standardized fares and increased cost recovery.

The following sections present information and performance data on each of the regions' nine transit agencies. Data sources include reports submitted by transit operators to NDDOT's Transit Section, statistics provided by the North Dakota Senior Services providers, and the National Transit Database (NTD). Agency profiles are presented in alphabetical order.

With regard to performance measure presentations on each service provider, no comparisons are made from one operator to another. Doing so would be inappropriate since the group is very heterogeneous. Some operators have very large and very rural service areas that provide primarily long-distance trips. Conversely, some systems operate in a relatively small area and provide primarily short-distance trips. Resulting performance measures would naturally be very different. 
It is, however, appropriate to look at an individual operator's measures over a number of years to identify related trends. These trends may provide insights concerning operator productivity and opportunities for improvement.

Most of the statistical tables in the following sections do not include revenue vehicle hour information for fiscal year (FY) 2007. That is because operators were not required to track that data until FY 2008. Unless otherwise indicated, all population data presented herein was derived from the 2010 census conducted by the U.S. Census Bureau.

\subsection{Bis-Man Transit}

Even though the focus of this study is the regions' rural transit providers, information on Bis-Man Transit is included because Bis-Man is a current and potential coordination partner with each of the regions' other operators. Bis-Man Transit is a private, nonprofit agency, and operates both dial-a-ride/paratransit and fixed-route systems in the Bismarck-Mandan metropolitan area. Unlike the regions' other agencies which receive federal transit monies via NDDOT, Bis-Man receives federal funding directly from the FTA. It also receives state aid funding from NDDOT and local mill levy support from the cities of Bismarck and Mandan. It had a total FY 2011 budget of \$3.15 million.

As indicated above, Bis-Man Transit operates both a fixed-route and dial-a-ride/paratransit bus system in Bismarck and Mandan. It also provides dial-a-ride/paratransit services within a two-mile radius surrounding the cities, in the adjacent city of Lincoln, and to the nearby University of Mary. Bis-Man Transit's service area is depicted in Figure 2.1.

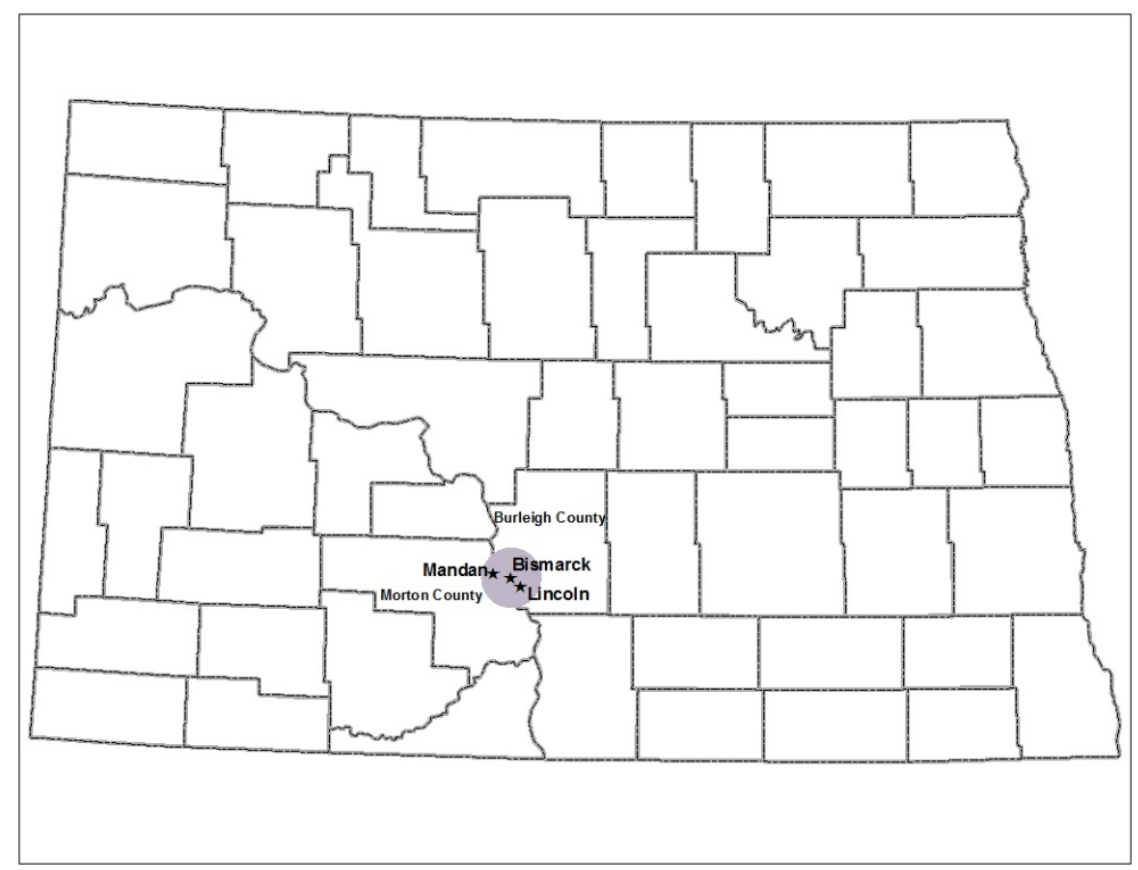

Figure 2.1 Bis-Man Transit - Service Area

According to the U.S. Census Bureau, Bismarck and Mandan had a 2010 aggregate population of 79,603. Using 2010 Census Bureau data, the Bismarck-Mandan Metropolitan Planning Organization estimates that 100,309 people live in or in close proximity to the two cities. In FY 2011, Bis-Man provided 296,545 one-way rides (171,892 paratransit and 124,653 fixed route). 
Bis-Man has a fleet of 42 vehicles. In FY 2011, its vehicles traveled a total of just over 1 million miles (685,729 for paratransit and 318,406 for fixed route). Its fixed-route service operates Monday through Saturday, while its paratransit services are available 24/7, including holidays. Paratransit services are available to senior citizens (age 60 and over) and to individuals with a verified disability; related rides must be scheduled at least one day in advance. One-way paratransit rides cost $\$ 2.50$, while fixed-route rides cost $\$ 1.25$. Discounts are available on a prepaid basis for both services.

To encourage and facilitate the utilization of local transit services, Bis-Man Transit employs a marketing director who provides travel training educational assistance to groups and individuals. This travel training service is also available to rural transit operators and their patrons who wish to use Bis-Man services.

Bis-Man Transit has a governing board which includes system users. The board operates under a contract with the city of Bismarck and acts as a broker to procure local transit services. In that role, it contracts with Central NoDak for administrative functions and with Taxi 9000 to provide actual transit services.

Given Bis-Man Transit's tangential role in this study, this review does not include related performance data. Most importantly, however, Bis-Man Transit is willing and able to coordinate its services with rural transit systems that are destined for the Bismarck-Mandan urban area. This coordination includes the travel training services discussed earlier, the transfer of riders from one system to another, and the occasional use of vehicles that may be necessitated by either unforeseen vehicle breakdowns or for scheduled maintenance. Bis-Man Transit's administrative headquarters and its vehicle maintenance and storage facilities are collocated with Taxi 9000, West River Transit, and intercity bus companies that serve the region.

\subsection{Dickey County Transportation}

Dickey County Transportation (DCT) is operated by Dickey County Senior Citizens (DCSC), a private, nonprofit organization that provides transit and other services in Dickey County in south central North Dakota. DCT's service area is depicted in Figure 2.2.

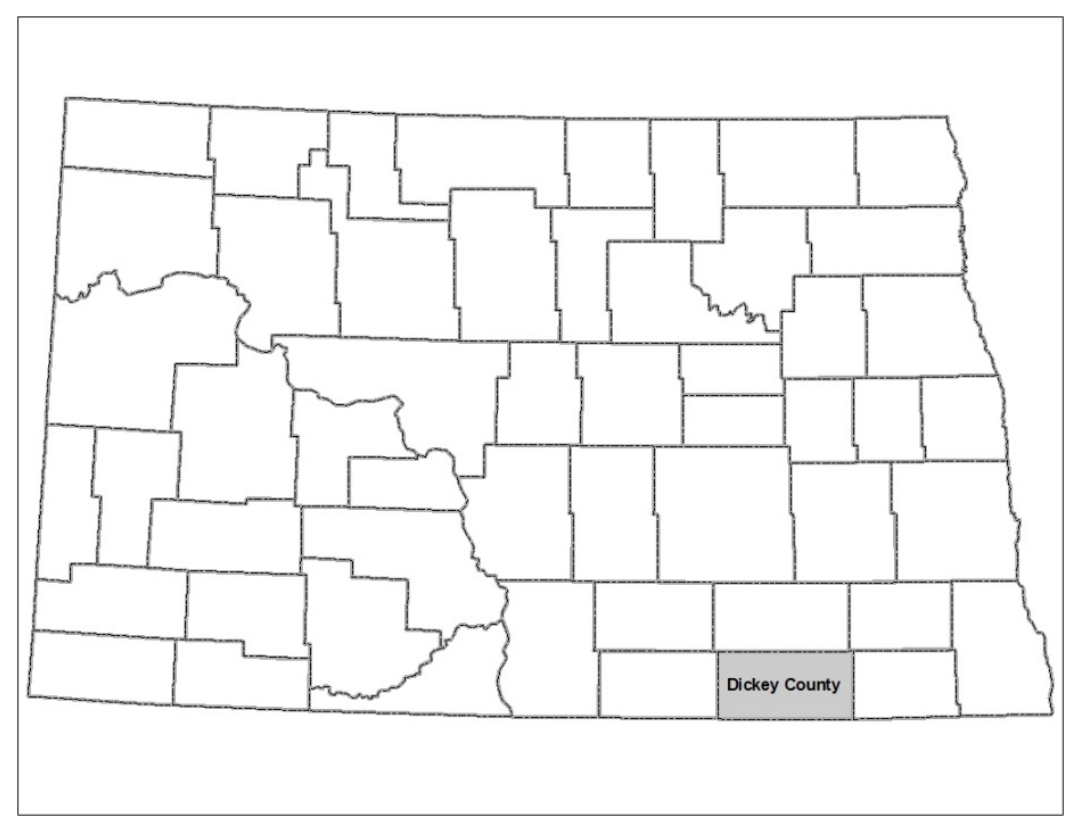

Figure 2.2 Dickey County Transportation - Service Area 
DCT is governed by DCSC's nine-person board of directors that oversees all of the organization's various functions, including transit. The board is comprised of three representatives from Oakes, three from Ellendale, one from Fullerton, and two at-large positions and meets at least three times annually. DCSC does not have a separate transit advisory board. Transit services in Dickey County are funded by federal Section 5311 and state aid monies; there is no city or county mill levy support for transit.

DCT's agency director oversees transit operations and senior citizen congregate meals, home delivered meals, and outreach. Her time is divided between senior center locations in Ellendale and Oakes. Approximately $20 \%$ of her time is devoted to transit administration.

Transit staffing consists of three part-time drivers and two back-up drivers. Riders call the senior centers in Oakes or Ellendale to reserve rides. DCT operates a 7 passenger van and a 14 passenger bus, both of which are handicapped accessible.

Demand-response service is available two days per week in Ellendale from 8:45 a.m. to 4:15 p.m. and two and a half days per week in Oakes. Service is also provided to Aberdeen, SD, once or twice per month, depending on demand. This service originates in Oakes and includes stops in Fullerton and Ellendale, if requested. The fare for local round-trips is $\$ 1$. The fare for trips to Aberdeen is $\$ 10$, equivalent to $\$ .125$ per mile for the 80 mile roundtrip from Ellendale. Service from Ellendale to Oakes is also provided twice a month; the fare for this service is $\$ 4$. Figure 2.3 illustrates Dickey County Transportation's routes within the county and to Aberdeen, SD.

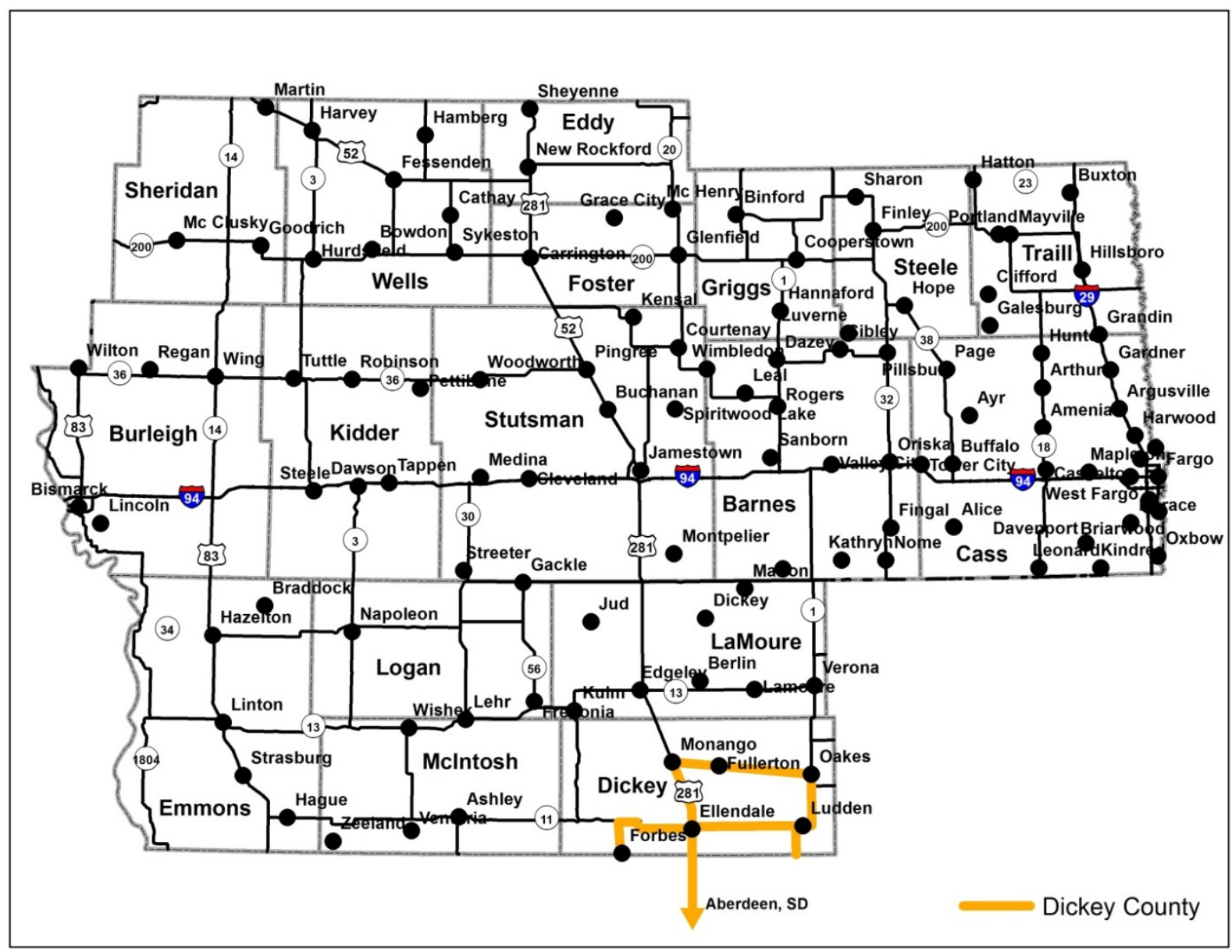

Figure 2.3 Dickey County Transportation - Routes to Regional Centers 
Table 2.1 presents 2007-2011 operating and performance statistics for DCT as reported to the National Transit Database (NTD). As this table indicates, DCT provided 6,075 one-way rides and traveled 11,770 miles in FY 2011. This table also indicates that DCT's ridership grew by nearly $111 \%$ from 2007 to 2011, while operating expenses per trip declined by $39 \%$. An even greater percentage decline would result if the table's operating expenses were adjusted for inflation. These performance results suggest significant productivity gains by DCT.

Table 2.1 Dickey County Transportation - Financial, Operating, and Performance Trends FY 2007-2011

\begin{tabular}{|c|c|c|c|c|c|c|}
\hline Underlying Data & 2007 & 2008 & 2009 & 2010 & 2011 & $\begin{array}{c}\text { Percent } \\
\text { Change } \\
\text { 2007-2011 } \\
\end{array}$ \\
\hline One-way passenger trips* & 2,879 & 3,108 & 3,988 & 5,460 & 6,075 & $+111.0 \%$ \\
\hline Vehicle revenue miles* & 14,054 & 11,765 & 11,674 & 13,011 & 11,770 & $-16.3 \%$ \\
\hline Vehicle revenue hours* & N.A. & 1,457 & 1,412 & 1,681 & 1,807 & $+24.0 \%$ \\
\hline Operating expenses* & $\$ 37,102$ & $\$ 35,867$ & $\$ 38,051$ & $\$ 42,708$ & $\$ 49,332$ & $+33.0 \%$ \\
\hline Service area population & 5,237 & 5,237 & 5,237 & 5,237 & 5,289 & $+1.0 \%$ \\
\hline \multicolumn{7}{|l|}{ Performance Measures } \\
\hline One-way trips/capita & 0.55 & 0.59 & 0.76 & 1.04 & 1.14 & $+107.3 \%$ \\
\hline One-way trips/mile & 0.20 & 0.26 & 0.34 & 0.42 & 0.52 & $+160.0 \%$ \\
\hline One-way trips/hour & N.A. & 2.13 & 2.82 & 3.25 & 3.36 & $+57.7 \%$ \\
\hline Operating expenses/mile & $\$ 2.64$ & $\$ 3.05$ & $\$ 3.26$ & $\$ 3.28$ & $\$ 4.04$ & $+53.0 \%$ \\
\hline Operating expenses/hour & N.A. & $\$ 24.62$ & $\$ 26.95$ & $\$ 25.41$ & $\$ 26.41$ & $+73 \%$ \\
\hline $\begin{array}{l}\text { Operating expenses/one- } \\
\text { way trip }\end{array}$ & $\$ 12.89$ & $\$ 11.54$ & $\$ 9.54$ & $\$ 7.82$ & $\$ 7.86$ & $-39.0 \%$ \\
\hline
\end{tabular}

* Source: National Transit Database

Perhaps more important than these productivity gains is DCT's growth in ridership and the fact that its one-way trips per capita increased by $107 \%$ from 2007 to 2011 . While still on the low end of national rural transit standards (one to two rides per capita), this increase is significant and is reflective of the fact that DCT is doing a better job of responding to the mobility needs of area residents.

There is relatively little overlap between DCT's service area and that of other transit service providers. DCT does, however, publicize the fact that South Central Transit Network travels through Ellendale twice per month on its way to Aberdeen, and local residents may contact South Central to access that service. Assistance is also provided to local residents who wish to travel to Fargo by helping them access Valley Senior Services buses that serve neighboring counties to the east of Dickey County. 


\subsection{City of Glen Ullin Public Transportation Program}

The city of Glen Ullin is a community of approximately 800 residents in west central North Dakota. It operates a one bus transit program with twice-monthly service to Bismarck and once-per-month service to Dickinson. Local service, primarily for senior meals, is provided four days per week during December, January, February, and March. Excursion trips are also offered to various regional destinations. Glen Ullin Public Transportation's service area is depicted in Figure 2.4. Its routes to nearby regional centers are illustrated in Figure 2.5.

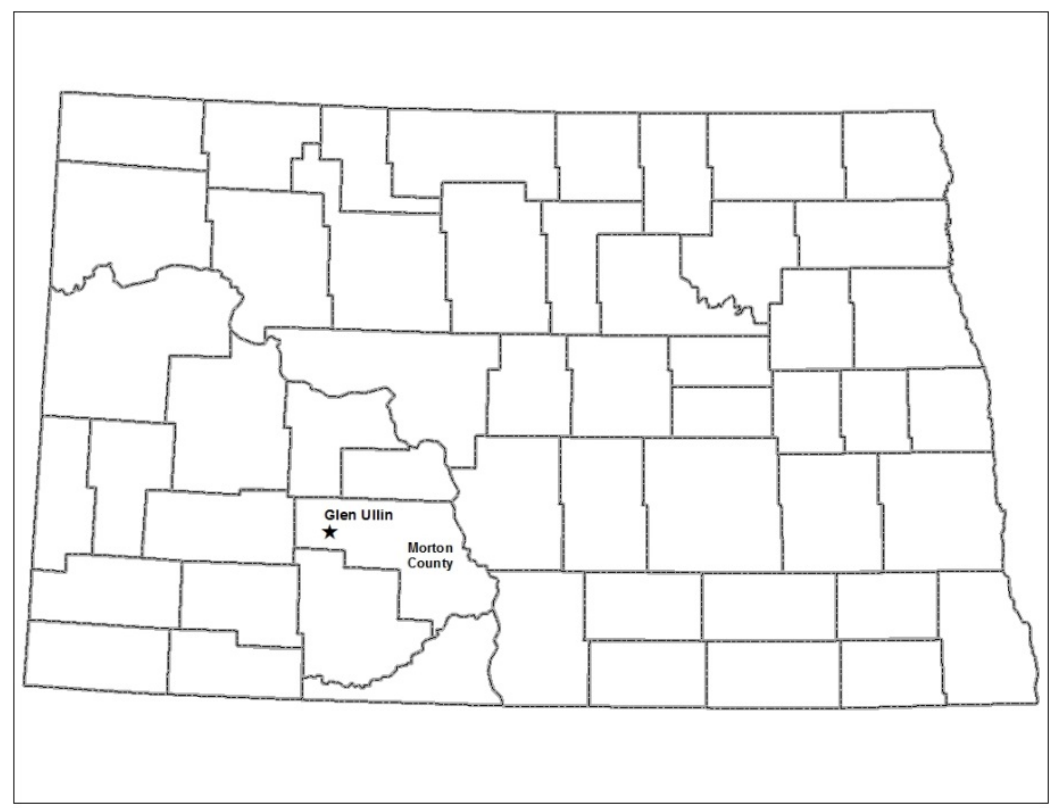

Figure 2.4 Glen Ullin Public Transportation - Service Area 


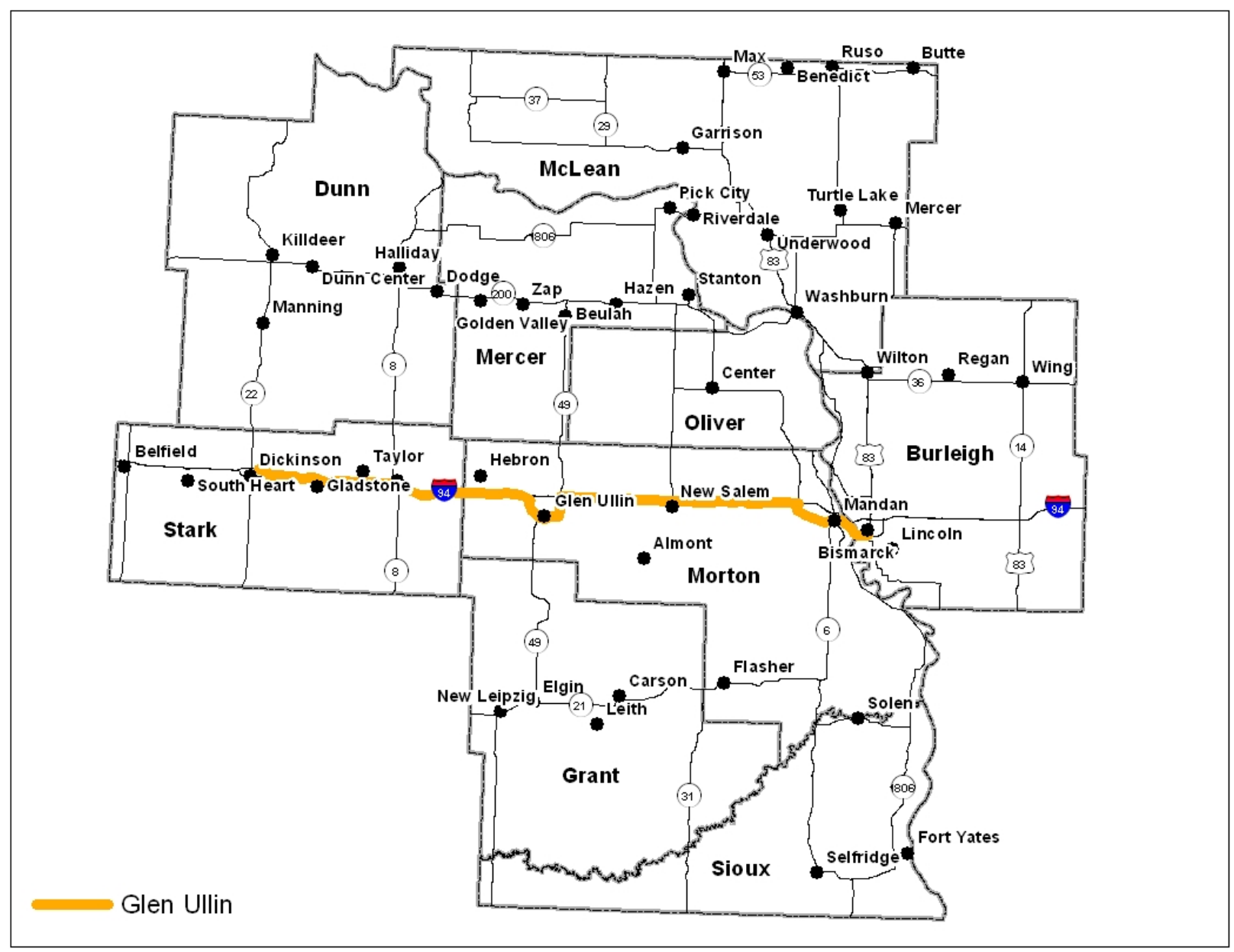

Figure 2.5 Glen Ullin Public Transportation - Routes to Regional Centers

Glen Ullin Public Transportation is a private, nonprofit organization. In early 2012, Glen Ullin's city council appointed a transit advisory board to receive input regarding local personal mobility needs and to monitor related program planning and service offerings. The advisory board reports to the city council. The program receives state aid funding administered by NDDOT's Transit Section, but it has not applied for, and therefore has not received, federal Section 5311 public transit funds which are administered by the NDDOT's Transit Section. There is no local mill levy support for transit. Several years ago the program received a significant bequest which is now used to subsidize the provision of local transit services.

The director of the program is a part-time employee who works approximately 20 to 30 hours per month. The service also employs one part-time driver and a substitute driver. Its one-vehicle fleet is a handicapped accessible, 17 passenger bus. The fare for local one-way trips is $\$ .50$. The fare for a 110 mile roundtrip to Bismarck is $\$ 5$, or about $\$ .045$ per mile. The fare for a 100 -mile roundtrip to Dickinson is also $\$ 5$, or about $\$ .05$ per mile.

Because Glen Ullin does not receive federal operating funds, its operating statistics are not reported to the NTD. It does, however, submit similar statistics to NDDOT's Transit Section. Glen Ullin's operating statistics and resulting performance measures are presented in Table 2.2. 
Table 2.2 Glen Ullin Public Transportation - Financial, Operating, and Performance Trends, FY 2007-2011

\begin{tabular}{|c|c|c|c|c|c|c|}
\hline Underlying Data & $2007 * *$ & 2008 & 2009 & 2010 & $2011 * * *$ & $\begin{array}{c}\text { Percent } \\
\text { Change } \\
\mathbf{2 0 0 7 - 2 0 1 1}\end{array}$ \\
\hline One-way passenger trips* & 906 & 1,474 & 577 & 622 & 1,151 & $+21.4 \%$ \\
\hline Vehicle revenue miles* & 5,183 & 5,824 & 4,952 & 5,323 & 5,181 & $0.0 \%$ \\
\hline Vehicle revenue hours* & N.A. & 431 & 287 & 317 & 390 & $-9.5 \%$ \\
\hline Operating expenses* & $\$ 9,130$ & $\$ 8,344$ & $\$ 7,455$ & $\$ 8,569$ & $\$ 9,380$ & $+2.7 \%$ \\
\hline Service area population & 796 & 796 & 796 & 796 & 807 & $+1.4 \%$ \\
\hline \multicolumn{7}{|l|}{ Performance Measures } \\
\hline One-way trips/capita & 1.14 & 1.85 & 0.72 & 0.78 & 1.43 & $-19.6 \%$ \\
\hline One-way trips/mile & 0.17 & 0.25 & 0.12 & 0.12 & 0.22 & $+24.9 \%$ \\
\hline One-way trips/hour & N.A. & 3.42 & 2.01 & 1.96 & 2.95 & $-17.5 \%$ \\
\hline Operating expenses/mile & $\$ 1.76$ & $\$ 1.43$ & $\$ 1.51$ & $\$ 1.61$ & $\$ 1.81$ & $+2.8 \%$ \\
\hline Operating expenses/hour & N.A. & $\$ 19.36$ & $\$ 25.98$ & $\$ 27.03$ & $\$ 24.05$ & $+24.2 \%$ \\
\hline Operating expenses/one-way trip & $\$ 10.08$ & $\$ 5.66$ & $\$ 12.92$ & $\$ 13.78$ & $\$ 8.15$ & $-15.4 \%$ \\
\hline
\end{tabular}

* Source: NDDOT's Transit Section

**Estimated data based on three quarters actual data and one quarter projection

*** Data reflect operator records vs. those reported to NDDOT's Transit Section

The operating data presented in Table 2.2 indicates that Glen Ullin Transportation averages about 7.5 hours of service each week and provides about 22 one-way rides per week or about 96 one-way trips per month. Providing these trips requires about 100 vehicle miles of service per week.

As indicated earlier, Glen Ullin Transportation provides three types of service - local, meal-related services during four winter months; three intercity trips per month to Bismarck and Dickinson; and excursion trips to destinations within the region. The program's director indicates that approximately half of the program's one-way trips are related to trips to Bismarck and Dickinson. Service is provided to Bismarck twice per month and typically involves about eight riders. Trips are made to Dickinson once per month and typically involve three to four riders.

The program director also indicated that local service, which is provided during four winter months, generates relatively few passengers. Therefore, a significant portion of the program's rides are related to excursion trips. Overall, none of Glen Ullin's performance measures are outside the norm, but its overall level of usage is quite low, based largely on the fact that its service area is limited to the city of Glen Ullin and its scope of service is quite narrow.

Glen Ullin has inquired to NDDOT's Transit Section about the availability of federal funds to purchase a new vehicle. While its vehicle is technically eligible for replacement based on its age, it has not reached the end of its useful life based on its low level of usage and corresponding odometer reading.

Glen Ullin Transportation has not coordinated its services with other area transit providers, but related opportunities were discussed as a part of this coordination pilot project. The outcome of those discussions will be discussed in Chapter 3. 


\subsection{City of Hazen Busing Project}

Hazen is located approximately 70 miles northwest of Bismarck and has a population of about 2,400. The city of Hazen operates an extensive local demand-response transit service which also provides weekly service to Bismarck and monthly service to Dickinson. Service to Bismarck is also made available to outlying Mercer County communities, including Center, Stanton, and Pick City.

Hazen Busing's service area is depicted in Figure 2.6. Its routes to regional centers are illustrated in Figure 2.7.

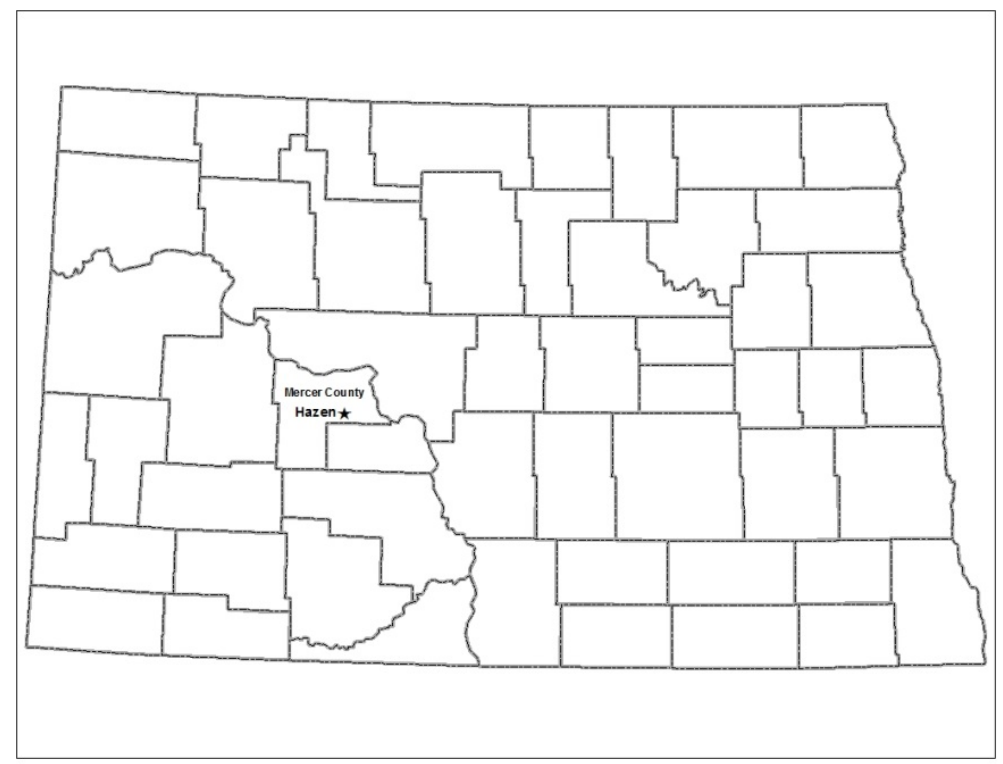

Figure 2.6 Hazen Busing - Service Area 


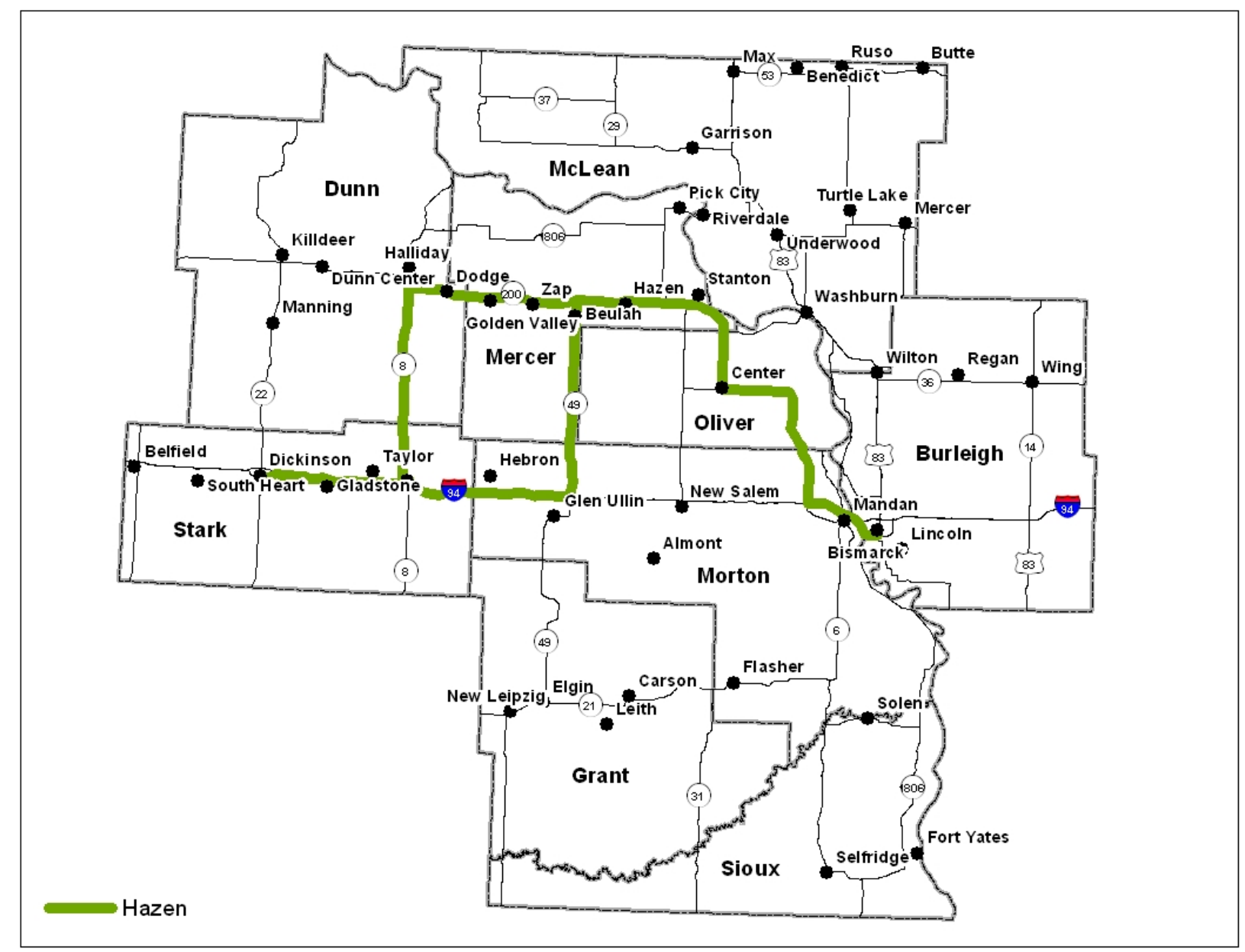

Figure 2.7 Hazen Busing - Routes to Regional Centers

Within Hazen, weekday service is provided from 7:30 a.m. to 5:30 p.m. Using federal Job Access Reverse Commute (JARC) funding, service was recently expanded to provide for an earlier start time in morning and a later end time in the afternoon. The program also began providing mid-day services during a time period when services were previously unavailable. New summer programs aimed at meeting youth transportation needs and contract services to address special needs have also been initiated.

The program is governed by the Hazen city council. The council has appointed a separate transit advisory board to monitor evolving personal mobility needs within the community, oversee daily operations, and provide feedback concerning the responsiveness of proposed service modifications. The advisory board reports to the city council.

Hazen Busing receives federal Section 5311 and state aid funding, both of which are administered by NDDOT's Transit Section. In addition to Bismarck and Mandan, Hazen is the only city in the two pilot regions that has passed a local mill levy to fund public transit. Hazen levies 5 mills to support its local transportation program, the maximum permitted by state law.

Hazen operates three vehicles with capacities ranging from 7 to 20 passengers; two of these vehicles are handicapped accessible. Until recently, the city auditor also served as the director of the transit program. 
The city auditor resigned in early September 2012, and a previously retired employee began overseeing transit operations on an interim basis.

Hazen Busing has five part-time drivers. Passengers wanting rides call the drivers or City Hall to request service. The fare for local one-way trips is $\$ .75$. The fare for a 146-mile roundtrip to Bismarck is $\$ 10$, or $\$ .068$ per mile. The fare for a 175 -mile roundtrip to Dickinson is also $\$ 10$, or $\$ .057$ per mile. In FY 2011 , the program provided 17,139 one-way rides and logged 29,023 vehicles miles.

Table 2.3 summarizes Hazen's 2007-2011 statistical performance. Related data for FY 2009, 2010, and 2011 are as reported to the NTD. Hazen did not receive federal financial support prior to 2009 and did not, therefore, send related reports to the NTD. Hazen's operating statistics for FY 2007 and 2008 are as reported to NDDOT's Transit Section.

As Table 2.3 indicates, Hazen's ridership grew by about 26\% from 2007 to 2011, while vehicle miles increased by more than $200 \%$. Overall operating expenses have increased by approximately $78 \%$.

Hazen Busing achieved an average of 8.35 one-way trips per vehicle hour. This level of utilization is significantly above the typical range for rural demand-response systems and is reflective of the fact that much of Hazen's ridership is on its in-town service that operates in a small geographic area and provides relatively short trips.

Regarding one-way trips per service area population, Hazen provided an estimated 7.1 trips per capita in FY 2011, well above the norm for rural transit system. This degree of market penetration is likely reflective of the provision of a high level of service.

Table 2.3 City of Hazen Busing - Financial, Operating, and Performance Trends, FY 2007-2011

\begin{tabular}{|c|c|c|c|c|c|c|}
\hline Underlying Data & 2007 & 2008 & 2009 & 2010 & 2011 & $\begin{array}{c}\text { Percent } \\
\text { Change } \\
\mathbf{2 0 0 7 - 2 0 1 1} \\
\end{array}$ \\
\hline One-way passenger trips* & $13,551 * *$ & 14,169 & 10,816 & 15,706 & 17,139 & $+26.5 \%$ \\
\hline Vehicle revenue miles* & 13,049 & 15,461 & 15,639 & 23,084 & 29,023 & $+212.1 \%$ \\
\hline Vehicle revenue hours* & N.A. & 2,487 & 1,483 & 2,021 & 2,052 & $-17.5 \%$ \\
\hline Operating expenses* & $\$ 51,657$ & $\$ 58,333$ & $\$ 60,869$ & $\$ 71,333$ & $\$ 92,164$ & $+78.4 \%$ \\
\hline Service area population & 2,200 & 2,200 & 2,200 & 2,200 & 2,411 & $+9.6 \%$ \\
\hline \multicolumn{7}{|l|}{ Performance Measures } \\
\hline One-way trips/capita & 6.15 & 6.44 & 4.92 & 7.14 & 7.10 & $+15.4 \%$ \\
\hline One-way trips/mile & 1.04 & 0.92 & 0.69 & 0.68 & 0.59 & $-43.3 \%$ \\
\hline One-way trips/hour & N.A. & 5.70 & 7.29 & 7.77 & 8.35 & $+46.5 \%$ \\
\hline Operating expense/mile & $\$ 3.96$ & $\$ 3.77$ & $\$ 3.89$ & $\$ 3.09$ & $\$ 3.17$ & $-20.0 \%$ \\
\hline Operating expense/hour & N.A. & $\$ 23.46$ & $\$ 41.04$ & $\$ 35.30$ & $\$ 44.91$ & $+91.4 \%$ \\
\hline Operating expense/one-way trip & $\$ 3.81$ & $\$ 4.12$ & $\$ 5.63$ & $\$ 4.54$ & $\$ 5.38$ & $+41.2 \%$ \\
\hline
\end{tabular}

*Source: 2007 and 2008 data reported to NDDOT's Transit Section. 2009-2011 data reported to NTD.

**Previously reported data corrected by operator (from 23,551 to 13,551 ) 
Hazen Busing coordinates its services with several local entities to provide transportation for specific clientele groups (senior meals, group homes, youth recreational activities, etc.) within the community and to the neighboring city of Beulah, which is located approximately eight miles west of Hazen. There are additional coordination-related opportunities relative to the Bismarck and Dickinson routes operated by both Hazen and West River Transit. Related discussions took place in early July 2012, as a part of this coordination pilot project. The outcome of those discussions will be discussed in Chapter 3 .

\subsection{James River Transit}

James River Transit (JRT) serves the city of Jamestown in south central North Dakota. It is operated by James River Senior Citizen's, Inc. (JRSC). It also manages Wells/Sheridan Transit, which has its main office at the senior center in Harvey. As its name suggests, this portion of JRT's services cover Wells and Sheridan counties. In 2010, Jamestown had a population of 15,427. Wells and Sheridan counties had an aggregate population of 5,528. JRT's service area is depicted in Figure 2.8. Its routes to other regional centers are illustrated in Figure 2.9.

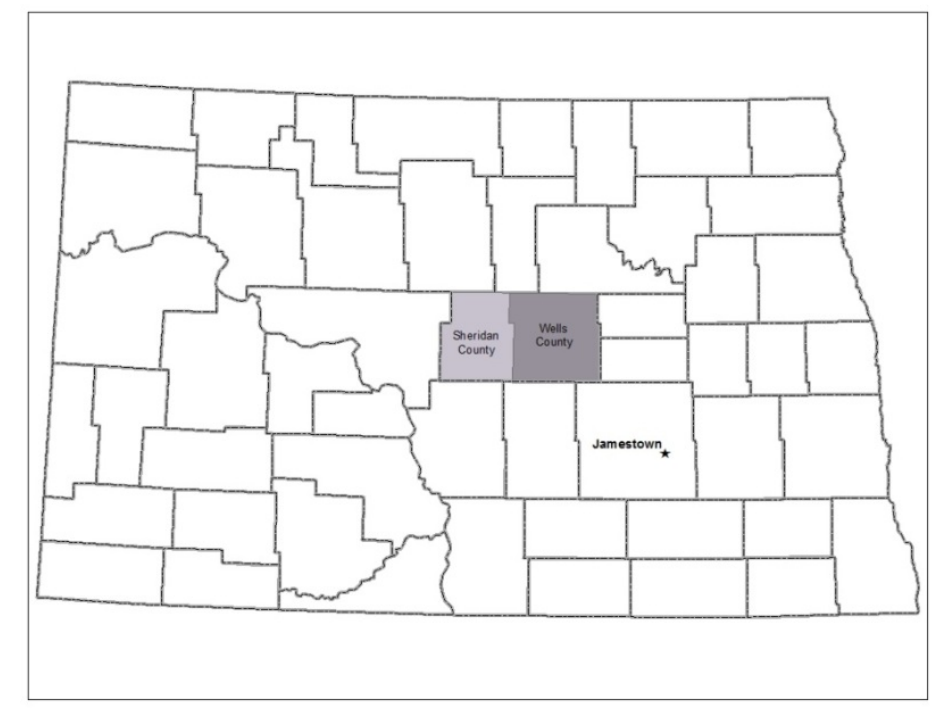

Figure 2.8 James River Transit - Service Area 


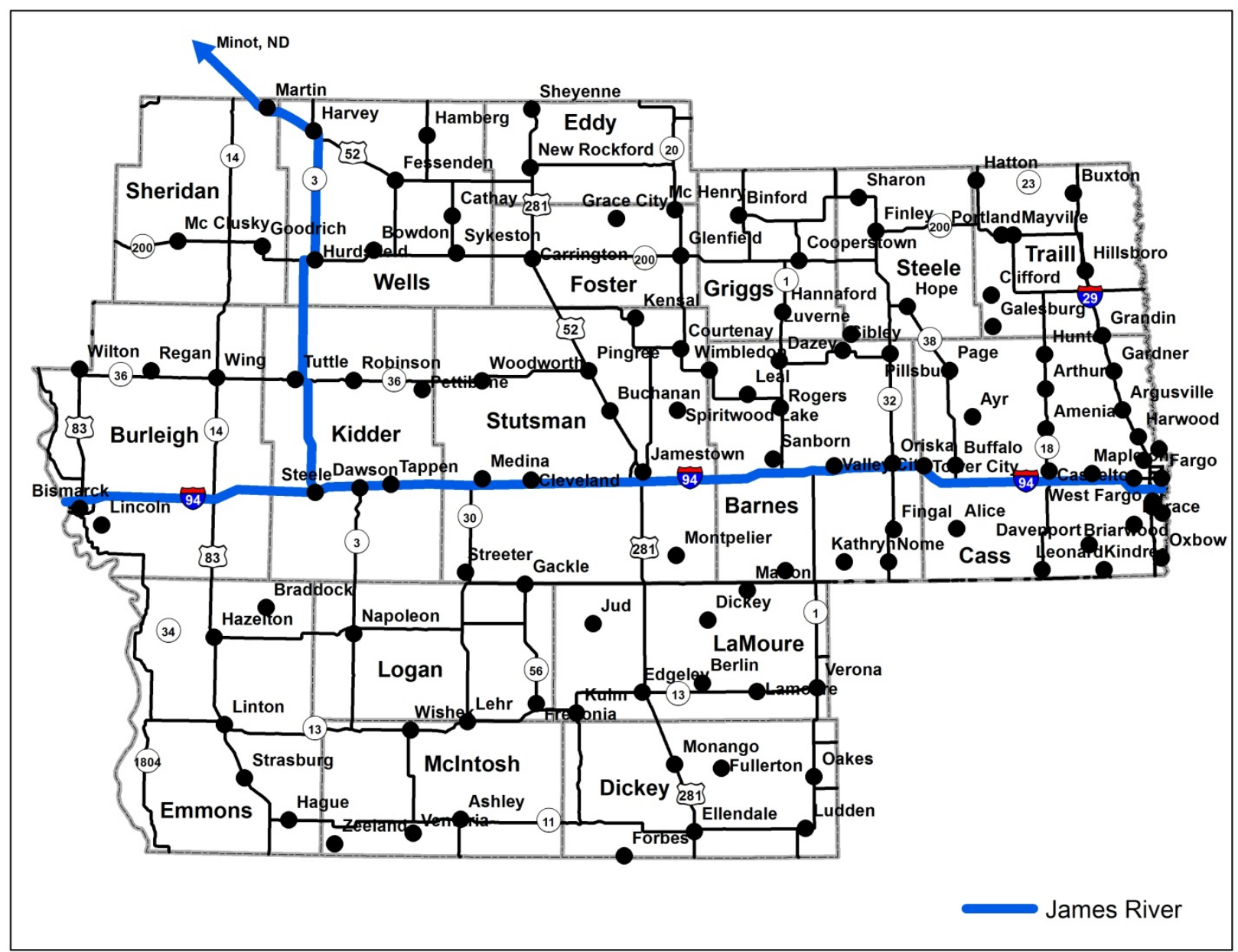

Figure 2.9 James River Transit - Routes to Regional Centers

In addition to transit services, JRSC also administers aging services programs, including congregate meals, home delivered meals, outreach in its service area, and a medical equipment loan program. Wells/Sheridan Transit also provides a frozen meal delivery program.

JRSC is a private, nonprofit organization governed by a board of directors with a representative named to the board by the county commission in Stutsman County. Wells/Sheridan County Aging Council (WSCAC) is a separate nonprofit agency which has an advisory board, which includes a county commissioner from each of its respective counties. WSCAC also has a representative on James River's board of directors. JRSC's board meets monthly, while the Wells/Sheridan board meets every other month. JRSC does not have a separate transit advisory board.

James River Transit is funded by federal Section 5311 and state aid funding plus a Stutsman County senior programs mill levy. Wells/Sheridan Transit also receives a portion of the Section 5311 funding provided to JRT plus its own allotment of state aid funding. In addition, Wells/Sheridan Transit receives senior programs mill levy money from both Wells and Sheridan counties. Separate fund accounting tracks each of the two transit operations. 
JRSC also operates a for-profit, sister business, Classic Catering, in Jamestown. Classic Catering's profits are all donated to JRSC and are used as local match for various government grant programs. These donations also provide steady cash flow which help JRSC pay expenses while it is waiting for grant reimbursement payments.

JRT provides demand-response service seven days per week, except on holidays, within the city of Jamestown. Hours of service are 6:30 a.m. to 5:30 p.m. weekdays (until 9:00 p.m. on Fridays), 8:00 a.m. to 9:00 p.m. on Saturdays, and 8:00 a.m. to 5:30 p.m. on Sundays.

Service to Bismarck and Fargo is offered on a weekly basis. JRT does not provide any service in rural Stutsman County, but Kidder County's transportation program provides rides to and from Jamestown to residents of Woodworth in northwestern Stutsman County.

In Jamestown, JRT has nine vehicles ranging from 6 to 14 passengers; all but one are handicapped accessible. Dispatch is not computerized and is handled through the central office in Jamestown. The fare for one-way trips is $\$ 2.50$. The fare for a 200 -mile roundtrip to either Fargo or Bismarck is $\$ 35$, or $\$ .175$ per mile.

Wells/Sheridan Transit provides demand-response service 8 a.m. to 5 p.m. Monday through Friday in Harvey. Service is provided from the outlying cities of Martin, Selz, and Fessenden to Harvey one day per week, upon request. Service is offered from Harvey to Minot monthly and to Bismarck twice per month. Wells/Sheridan Transit operates three vehicles ranging from 6 to 14 passengers; only the minivan is not handicapped accessible. The fare for local, one-way trips is $\$ 1.50$. Wells-Sheridan charges $\$ 30$ for a 220 mile roundtrip from Harvey to Bismarck, or 13.6 cents per mile. The fare from Harvey to Minot is \$20, which also equals 13.6 cents per mile.

JRT has an executive director who manages all transit operations, aging services programs, and other business interests of the organization. The agency has a full-time secretary and full-time office manager. JRT has a full-time fleet manager who also serves as a driver, a full-time billing clerk who also serves as a backup dispatcher, one full-time and one part-time dispatcher, and 18 part-time drivers.

Wells/Sheridan Transit has a full-time coordinator who oversees transit operations, aging services programs, and a gaming operation for the two counties. There is also a part-time secretary.

Wells/Sheridan Transit has one full-time and two part-time drivers. Ride reservations are made by calling the main office. Dispatch duties are handled by an Experience Works staff member in the mornings and by the secretary in the afternoon.

In FY 2011, JRT, including Wells/Sheridan Transit, provided 77,548 one-way rides and its transit vehicles traveled 225,593 miles. Related performance statistics are presented in Table 2.4. As this table indicates, JRT's ridership has increased by more than 20\% from 2007 to 2011 . Vehicle miles and vehicle hours increased by approximately the same rate as passenger trips; overall operating expenses increased by about $37 \%$ from 2007 and 2011 .

Note that Table 2.4's monetary figures are not adjusted for inflation. Doing so would undoubtedly put JRT's operating cost increases more in line with vehicle mile and vehicle hour increases. Similarly, such an adjustment would reveal that JRT has experienced some productivity gains in terms of operating expenses per vehicle hour and vehicle mile. 
Table 2.4. James River Transit - Financial, Operating, and Performance Trends, FY 2007-2011

\begin{tabular}{|l|r|r|r|r|r|r|}
\hline \multicolumn{1}{|c|}{ Underlying Data } & $\mathbf{2 0 0 7}$ & $\mathbf{2 0 0 8}$ & \multicolumn{1}{c|}{$\mathbf{2 0 0 9}$} & \multicolumn{1}{c|}{$\mathbf{2 0 1 0}$} & \multicolumn{1}{c|}{$\mathbf{2 0 1 1}$} & $\begin{array}{c}\text { Percent } \\
\text { Change } \\
\mathbf{2 0 0 7 - 2 0 1 1}\end{array}$ \\
\hline One-way passenger trips* & 64,416 & 72,027 & 72,693 & 73,542 & 77,548 & $+20.4 \%$ \\
\hline Vehicle revenue miles* & 185,085 & 204,628 & 215,290 & 201,773 & 225,593 & $+21.9 \%$ \\
\hline Vehicle revenue hours* & N.A. & 13,525 & 14,748 & 15,471 & 16,880 & $+24.8 \%$ \\
\hline Operating expenses* & $\$ 463,142$ & $\$ 480,823$ & $\$ 511,042$ & $\$ 580,750$ & $\$ 636,310$ & $+37.4 \%$ \\
\hline Service area population & 25,851 & 25,851 & 25,851 & 25,851 & 26,628 & $+3.0 \%$ \\
\hline & & & & & & \\
\hline Performance Measures & & & & & & \\
\hline One-way trips/capita & 2.49 & 2.79 & 2.81 & 2.84 & 2.91 & $+16.9 \%$ \\
\hline One-way trips/mile & 0.35 & 0.35 & 0.34 & 0.36 & 0.34 & $-2.9 \%$ \\
\hline One-way trips/hour & N.A. & 5.33 & 4.93 & 4.75 & 4.59 & $-13.9 \%$ \\
\hline Operating expenses/mile & $\$ 2.50$ & $\$ 2.35$ & $\$ 2.37$ & $\$ 2.88$ & $\$ 2.57$ & $-2.8 \%$ \\
\hline Operating expenses/hour & N.A. & $\$ 35.55$ & $\$ 34.65$ & $\$ 37.54$ & $\$ 34.38$ & $-3.3 \%$ \\
\hline $\begin{array}{l}\text { Operating expenses/one-way } \\
\text { trip }\end{array}$ & $\$ 7.19$ & $\$ 6.68$ & $\$ 7.03$ & $\$ 7.90$ & $\$ 7.48$ & $+4.0 \%$ \\
\hline
\end{tabular}

*Source: National Transit Database

James River's productivity in terms of one-way trips per hour has declined slightly every year since 2008 and now stands at 4.59. This level of productivity is still good for rural systems and is undoubtedly due, in large part, to the high concentration of relatively short trips provided in Jamestown, a small urban area with a population 15,487 . JRT's market penetration, as measured by one-way trips per capita, increased by nearly $17 \%$ from 2007 to 2011 .

As indicated earlier, James River operates two significantly different operations. Its Stutsman County services are largely tied to the small urban city of Jamestown, while its operations in Wells and Sheridan counties are more typical of a rural transit system. The performance measures presented in Table 2.4 are reflective of its total operations and may, therefore, mask what might be expected of either subpart. James River may, therefore, want to track performance measures separately for Jamestown and Wells/Sheridan in order to monitor the performance of each of its component systems.

JRT reaches out to provide weekend and evening service to private service providers such as local nursing homes and Jamestown's Anne Carlsen Center for Children. Locally, JRT also coordinates its services with the local taxi service by providing related contact information to callers who want more immediate service than JRT provides.

With regard to coordination activities with other public transit operators, JRT transports Jamestown residents to Valley City to access interline service to Fargo via South Central Transit Network on days when JRT does not travel to Fargo. In Wells and Sheridan counties, JRT has, on occasion, coordinated its services with Benson County Transit to transport local residents to Bismarck and Minot. Additional coordination-related opportunities related to both JRT and its Wells-Sheridan component were discussed in mid-June 2012, as a part of this coordination pilot project. The outcome of those discussions will be discussed in Chapter 3. 


\subsection{Kidder County Transit}

Kidder Emmons Senior Services operates transit services in Kidder County from its central office in Steele, the county seat. It is a private, nonprofit organization governed by the Kidder County Council on Aging, which also serves as its board of directors. The 12-member board has one representative from each city in Kidder and Emmons counties. Term limits are set at six years, unless replacements are unable to be found (which is often the case). The council does not have a separate transit advisory board.

Kidder County Transit (KCT) has a full-time director who also oversees the county's senior citizens program and serves as its bookkeeper. It has one full-time driver and a substitute driver. KCT receives federal Section 5311 and state aid funding. It also uses part of the county's senior programs mill levy to fund transportation.

KCT provides transit services from the county's cities to Bismarck and Jamestown and limited demandresponse services in Steele, Pettibone, Robinson, and Tuttle. As indicated earlier, it also provides service from Woodworth in far northwest Stutsman County to Jamestown. KCT's service area is depicted in Figure 2.10. Its routes to regional centers are illustrated in Figure 2.11.

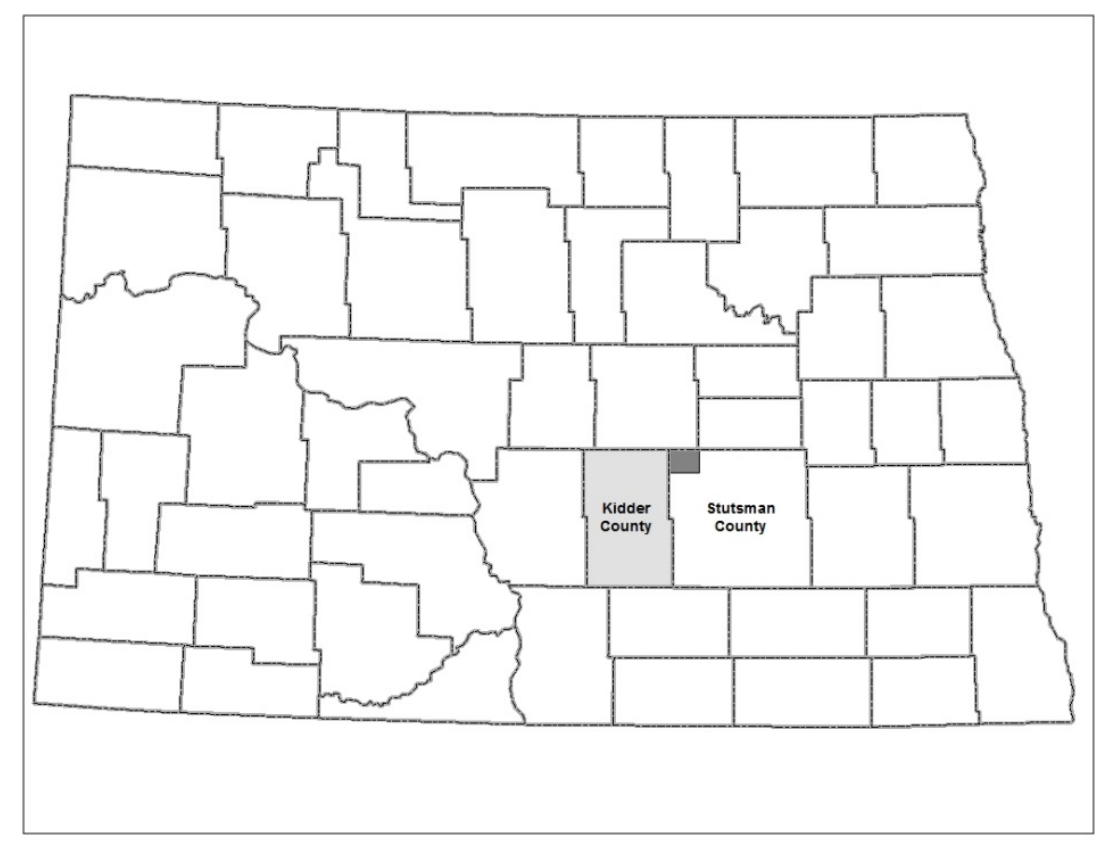

Figure 2.10 Kidder County Transit - Service Area 


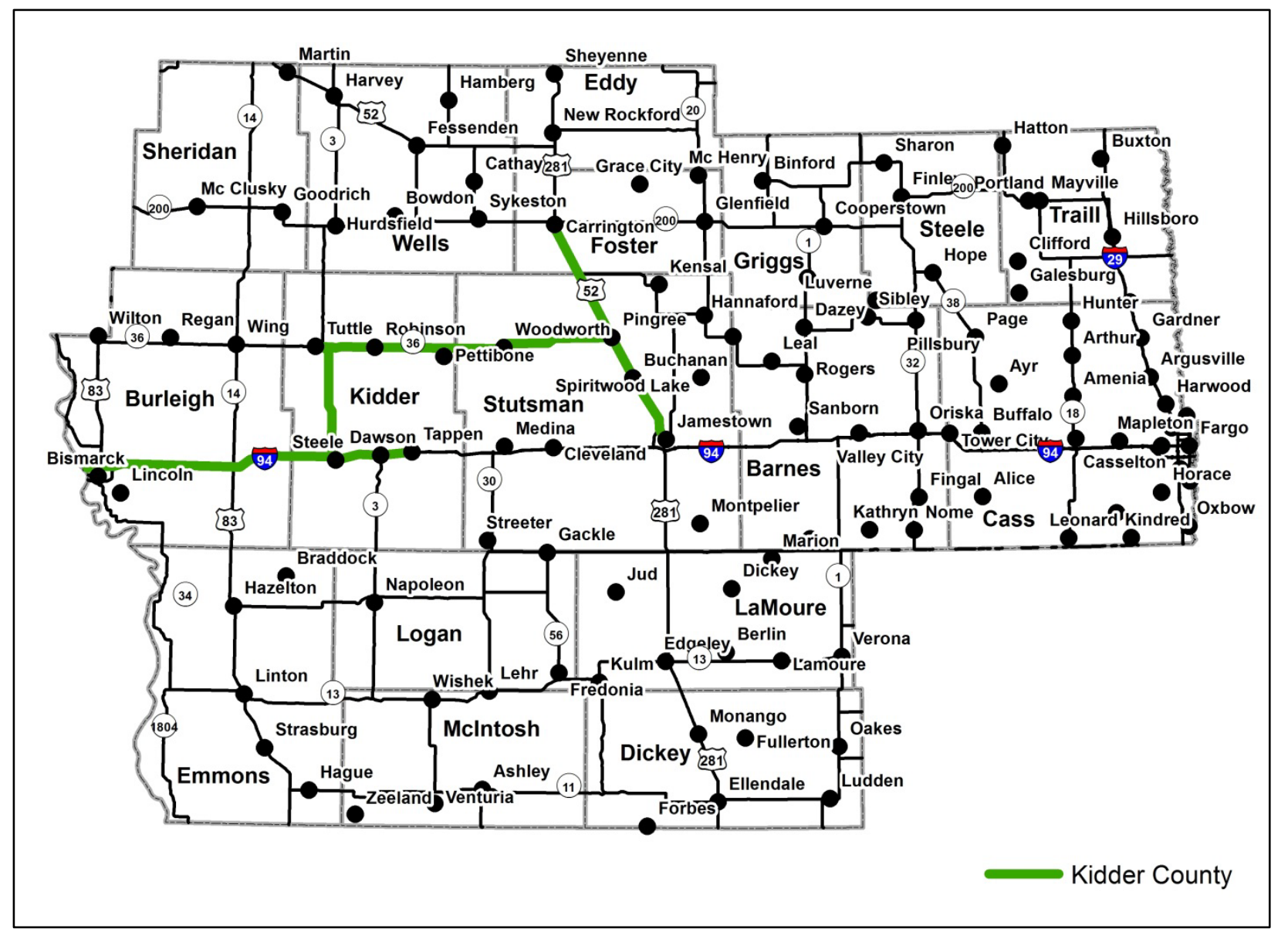

Figure 2.11 Kidder County Transit - Routes to Regional Centers

KCT operates a 22-passenger bus (non-accessible) and two 7-passenger vans, one of which is handicapped accessible. The vehicles are based in Tuttle, Pettibone, and Steele. Passengers in the northern tier of the county call the driver directly to reserve rides, while passengers in the south end of the county call the senior center in Steele. The driver calls the center the day before trips are to be provided to get a passenger log.

KCT charges a $\$ .50$ fare for local, one-way trips. The fare for a 90 mile roundtrip from Steele to Bismarck is $\$ 8$, or $\$ .089$ per mile. In FY 2011, KCT provided 6,571one-way rides, and its vehicles traveled 46,350 miles to provide related services.

KCT's 2007-2011 performance statistics are presented in Table 2.5. This table suggests that ridership declined by more than $25 \%$ from 2007 to 2011 . Note, however, that a part of that decline is related to the fact that KCT provided transit services in Emmons County until 2009, at which point South Central Transit assumed related operations. Riders that were previous reported by KCT are now reflected in South Central's statistics.

KCT's $\$ 50.33$ in operating expenses per vehicle hour is significantly higher than the state average for rural systems, but it has shown improvement since 2009 (down from $\$ 52.23$ to $\$ 50.33$ ). KCT provided 3.86 one-way trips per vehicle hour in 2011. This level of utilization is good for a rural system. 
Table 2.5 Kidder County Transit - Financial, Operating, and Performance Trends, FY 2007-2011

\begin{tabular}{|c|c|c|c|c|c|c|}
\hline Underlying Data & 2007 & 2008 & 2009 & 2010 & 2011 & $\begin{array}{c}\text { Percent } \\
\text { Change } \\
\text { 2007-2011 } \\
\end{array}$ \\
\hline One-way passenger trips* & 8,845 & 8,023 & 7,476 & 6,859 & 6,571 & $-25.7 \%$ \\
\hline Vehicle revenue miles* & 44,609 & 39,341 & 41,284 & 43,059 & 46,350 & $+3.9 \%$ \\
\hline Vehicle revenue hours* & N.A. & 1,474 & 1,323 & 1,533 & 1,704 & $+15.6 \%$ \\
\hline Operating expenses* & $\$ 70,854$ & $\$ 63,745$ & $\$ 69,103$ & $\$ 73,929$ & $\$ 85,763$ & $+21.0 \%$ \\
\hline Service area population & 2,290 & 2,290 & 2,290 & 2,290 & 2,435 & $+6.3 \%$ \\
\hline \multicolumn{7}{|l|}{ Performance Measures } \\
\hline One-way trips/capita & 3.86 & 3.50 & 3.26 & 3.00 & 2.70 & $-30.1 \%$ \\
\hline One-way trips/mile & 0.20 & 0.20 & 0.18 & 0.16 & 0.14 & $-30.0 \%$ \\
\hline One-way trips/hour & N.A. & N.A. & 5.65 & 4.47 & 3.86 & $-31.9 \%$ \\
\hline Operating expenses/mile & $\$ 1.59$ & N.A. & $\$ 1.67$ & $\$ 1.72$ & $\$ 1.85$ & $+16.4 \%$ \\
\hline Operating expenses/hour & N.A. & N.A. & $\$ 52.23$ & $\$ 48.23$ & $\$ 50.33$ & $-3.6 \%$ \\
\hline Operating expenses/one-way trip & $\$ 8.01$ & N.A. & $\$ 9.24$ & $\$ 10.78$ & $\$ 13.05$ & $+62.9 \%$ \\
\hline
\end{tabular}

*Source: National Transit Database

As indicated earlier, KCT also provides service to residents of northwestern Stutsman County who wish to travel to Jamestown. There are several other situations where KCT could coordinate its services with those of other area service providers. These opportunities include James River Transit and South Central Transit Network trips through Kidder County destine for Bismarck and Bismarck-bound trips made by both Wells-Sheridan and Benson counties through northern Kidder County. Related discussions took place in mid-June 2012, as a part of this coordination pilot project. The outcome of those discussions will be discussed in Chapter 3.

KCT has undergone multiple administrative staffing changes in recent years. As is the case with any transit system, and given the complexity of managing state and federal funding programs and day-to-day operations, there is a significant learning curve for incoming personnel. Related discussions took place as a part of the pilot coordination project regarding the possible benefits of an arrangement similar to the one that exist between James River Transit and Wells and Sheridan counties, whereby James River Transit oversees most administrative activities, and Wells/Sheridan personnel handle day-to-day operational matters.

As a result of these discussions and related observations, SURTC personnel recommended that NDDOT's Transit Section contact KCT's director to see if there was a desire and willingness to pursue a cooperative arrangement similar to the one that exists between JRT and Wells and Sheridan counties. Those discussions were held and affirmation was received. Subsequent conversations were then held with the director of JRT. It is expected that direct discussions will take place between KCT and JRT. The end result may be more efficient and effective administrative operations and an increase in personal mobility options for the residents of Kidder County. 


\subsection{South Central Transit Network}

South Central Transit Network (SCTN) provides local and long distance transit services in seven counties in south central North Dakota. It is managed by South Central Adult Services Council, Inc. (SCASC) and is headquartered in Valley City. As depicted in Figure 2.12, its transit service area includes Barnes, Emmons, Foster, Griggs, LaMoure, Logan, and McIntosh counties. It is a private, nonprofit corporation that is also the legal entity for the operation of senior service programs in 10 counties. SCTN's routes to regional centers are illustrated in Figure 2.13.

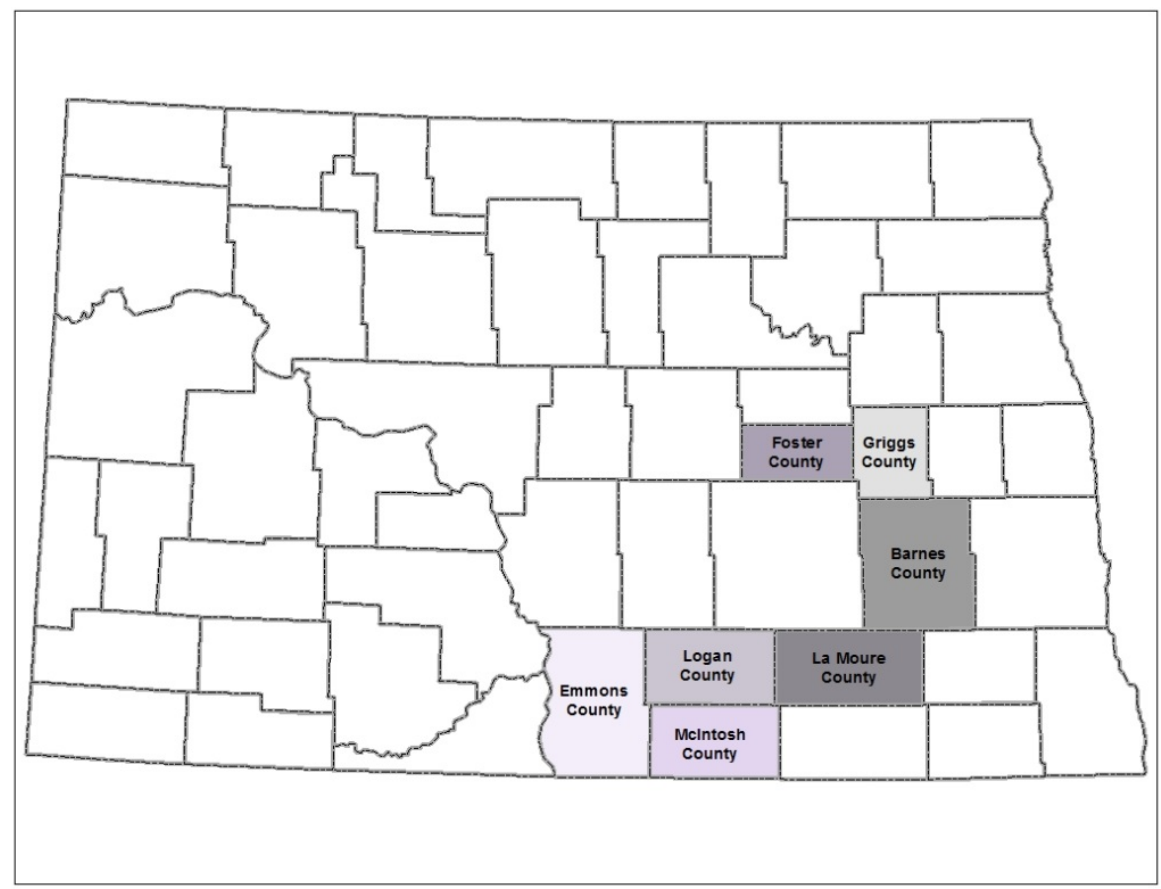

Figure 2.12 South Central Transit Network - Service Area 


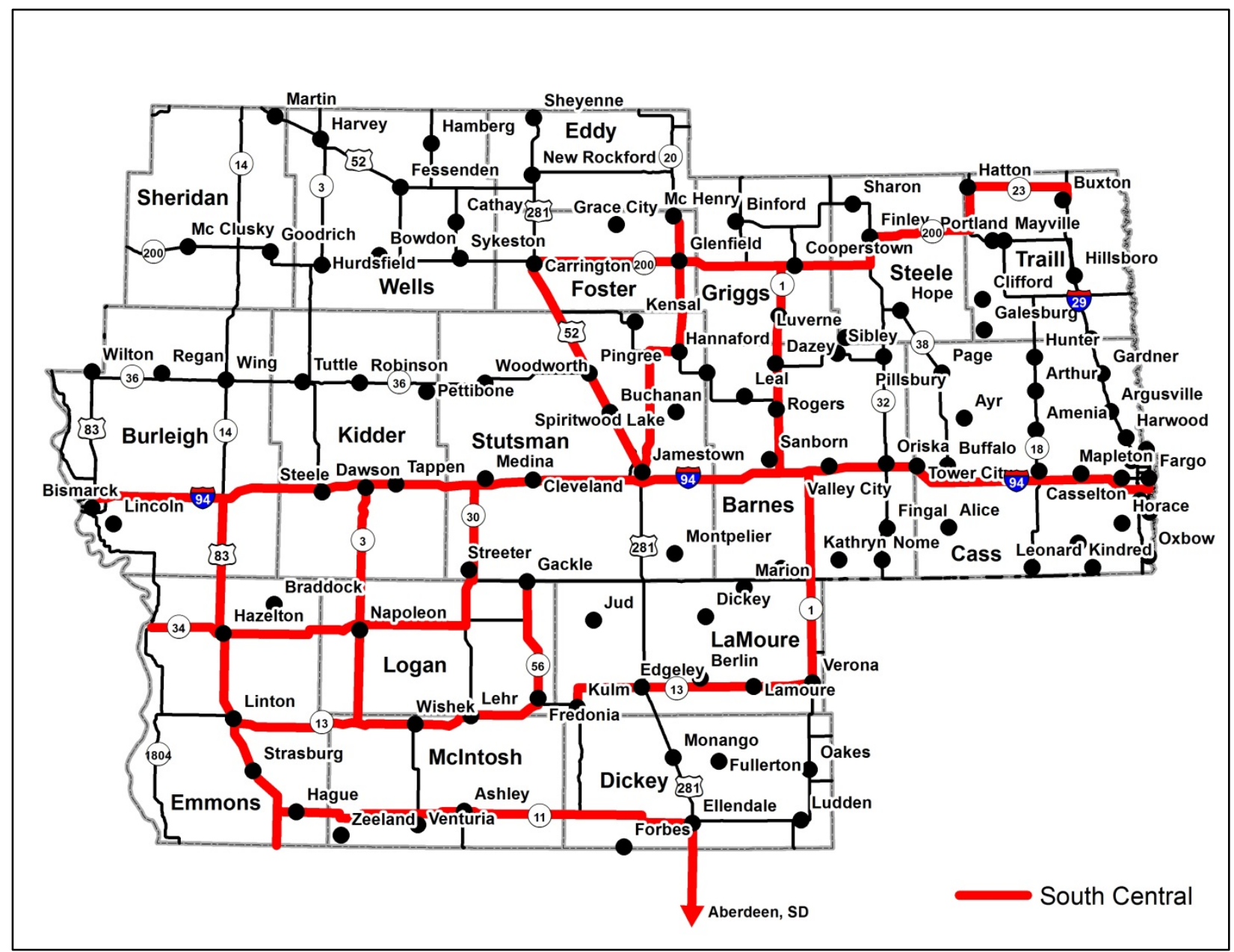

Figure 2.13 South Central Transit Network - Routes to Regional Centers

Along with the local hospital, SCASC owns and operates a 44-bed assisted living facility in Valley City, and manages a prescription drug program funded by the Dakota Medical Foundation in Fargo. In addition to its senior services program, it operates the Barnes County Food Pantry, a chore service program, a prescription assistance program, and a durable medical equipment loan closet. It also offers a volunteer driver program for people requiring cancer treatments.

SCTN receives federal Section 5311 and state aid funding. Barnes County is the only one of the program's seven counties that contributes senior services mill levy money to support the provision of transit services. SCTN has an annual transit operating budget of more than $\$ 1$ million.

SCASC has a board of directors with representation from six of the seven counties served by the transit network. The board meets quarterly. Each of the seven counties also has its own aging council, which meets quarterly. While SCASC does not have a separate transit advisory board, the county aging councils are responsible for the transit programs in their respective counties. The director of SCASC serves as the director of SCTN and meets individually with each of the aging services councils each quarter. 
SCTN provides demand-response services to cities in its service area and regularly scheduled services from these communities to major hubs such as Fargo and Bismarck. Service routes and schedules vary by county. The fare for a one-way trip in Valley City is \$2. The fare for a 270-mile roundtrip from Valley City to Bismarck is $\$ 10$ or $\$ .037$ per mile. The fare for a 124-mile roundtrip from Valley City to Fargo is also $\$ 10$, or $\$ .08$ per mile. SCTN also operates a $24 / 7$ taxi service in Valley City.

SCTN has 26 vehicles, 19 of which are handicapped accessible. These vehicles are located throughout the seven-county service area. SCTN does not have centralized dispatch. In some cases, passengers call directly to the local driver or to a local senior services outreach worker. In Valley City, the largest community in SCTN's service area, people call SCTN's central office to reserve rides.

As mentioned earlier, SCTN's director oversees a number of different programs under the SCASC umbrella. She is assisted by a full-time bookkeeper and secretary. A transit coordinator position was recently added to the staff. There are five part-time outreach workers whose primary functions are under the aging services program, but who also take ride reservations in their respective areas. SCTN has one full-time dispatcher, three part-time dispatchers, four full-time drivers and 25 part-time drivers. In FY 2011, SCTN provided 105,299 one-way rides and its vehicles traveled 722,498 miles.

SCTN's current and historic performance statistics are presented in Table 2.6. As this table illustrates, ridership increased by 145\% from 2007 to 2011, while the number of vehicle miles traveled increased by over $210 \%$. As is obvious from these statistics, SCTN has grown rapidly in the past few years. As indicated earlier, it took over the provision of transit services in Emmons County from KCT in 2009.

Overall operating expenses grew by $192 \%$ from 2007 to 2011 , while expenses per mile declined by $11 \%$. South Central's $\$ 19.20$ expense per hour is the lowest in the two pilot regions and is one of the lowest in the state. In 2007, South Central provided nearly 3.6 trips per capita in its seven county region. This measure of market penetration has increased by more than 130\% since 2007 . 
Table 2.6 South Central Transit Network - Financial, Operating, and Performance Trends, FY 2007-2011

\begin{tabular}{|c|c|c|c|c|c|c|}
\hline Underlying Data & 2007 & 2008 & 2009 & 2010 & 2011 & $\begin{array}{c}\text { Percent } \\
\text { Change } \\
\text { 2007-2011 } \\
\end{array}$ \\
\hline One-way passenger trips* & 44,000 & 55,154 & 62,779 & 83,472 & 105,299 & $139.3 \%$ \\
\hline Vehicle revenue miles* & 232,500 & 327,983 & 424,010 & 592,519 & 722,498 & $210.8 \%$ \\
\hline Vehicle revenue hours* & N.A. & 29,710 & 35,555 & 42,636 & 51,958 & $74.9 \%$ \\
\hline Operating expenses* & $\$ 360,846$ & $\$ 440,006$ & $\$ 566,910$ & $\$ 781,278$ & $\$ 1,054,286$ & $192.2 \%$ \\
\hline Service area population & 28,432 & 28,432 & 28,432 & 28,432 & 29,317 & $3.1 \%$ \\
\hline \multicolumn{7}{|l|}{ Performance Measures } \\
\hline One-way trips/capita & 1.55 & 1.94 & 2.21 .9 & 2.94 & 3.59 & $+131.6 \%$ \\
\hline One-way trips/mile & 0.19 & 0.17 & 0.15 .4 & 0.14 & 0.15 & $-21.1 \%$ \\
\hline One-way trips/hour & N.A. & 1.86 & 1.77 & 1.96 & 2.02 & $+8.6 \%$ \\
\hline Operating expenses/mile & $\$ 1.55$ & $\$ 1.34$ & $\$ 1.34$ & $\$ 1.32$ & $\$ 1.38$ & $-11.0 \%$ \\
\hline Operating expenses/hour & N.A. & $\$ 14.81$ & $\$ 15.94$ & $\$ 18.32$ & $\$ 19.20$ & $+29.6 \%$ \\
\hline Operating expenses/one-way trip & $\$ 8.20$ & $\$ 7.98$ & $\$ 9.03$ & $\$ 9.36$ & $\$ 9.47$ & $+15.5 \%$ \\
\hline
\end{tabular}

Source: National Transit Database

As indicated earlier, SCTN coordinates with James River Transit regarding the provision of some transit service to Fargo and with Dickey County on some trips to Aberdeen, SD. There are additional instances when SCTN has coordinated with other area service providers to help meet the mobility needs of area residents.

With an extremely large service area, SCTN's service territory comes in contact with several other service providers, and there are related opportunities for further and more formalized coordination initiatives.

These opportunities include coordinating with Kidder County and James River Transit on the provision of services from Kidder County to Bismarck, with counties in far southeastern North Dakota regarding services to Fargo and Wahpeton, and counties in central North Dakota for the provision of services to Devils Lake and Grand Forks. Related discussions took place in June and July 2012, as a part of this coordination pilot project. The outcome of those discussions will be discussed in Chapter 3 .

\subsection{Standing Rock Public Transit}

Standing Rock Public Transit (SRPT) provides public transportation services to, from, and on the Standing Rock Indian Reservation in Sioux County, North Dakota, and Corson County, South Dakota. As part of tribal government, SRPT receives funding directly from the federal Section 5311(c) tribal transit program, plus it also receives 5311 and 5311(f) funding administered by North and/or South Dakota. It also receives state funding from both North Dakota and South Dakota for services provided in each state, and from Sitting Bull College and the Standing Rock Sioux Tribe.

Sitting Bull College of Ft. Yates is the official grantee for SRPT. The service has an advisory committee comprised of local representatives who have a vested interest in the provision of transit services. SRPT is ultimately responsible to Sitting Bull College's board of trustees. The system employs a full-time director, coordinator, finance clerk, and dispatcher. It has seven full-time and two part-time drivers. 
SRPT provides weekday demand-response and scheduled routes on the reservation, with additional daily routes to and from Bismarck-Mandan. Service is provided from early morning to late afternoon. A $\$ 1$ fare is charged for local, one-way trips. The fare for a 136-mile roundtrip to Bismarck is \$10, or \$.074 per mile.

SRPT, in conjunction with River Cities Public Transit of Pierre, SD, also provides twice-weekly intercity bus service between Munro, SD, and Bismarck, ND; SRPT operates the Bismarck to Mobridge, SD, portion of this route. This service provides direct access to Rapid City and Sioux Falls, SD. SRPT also provides veteran's service twice monthly to Sturgis, SD, and Fargo, ND. SRPT's North Dakota service area is depicted in Figure 2.14. The North Dakota portion of its routes to regional centers is illustrated in Figure 2.15.

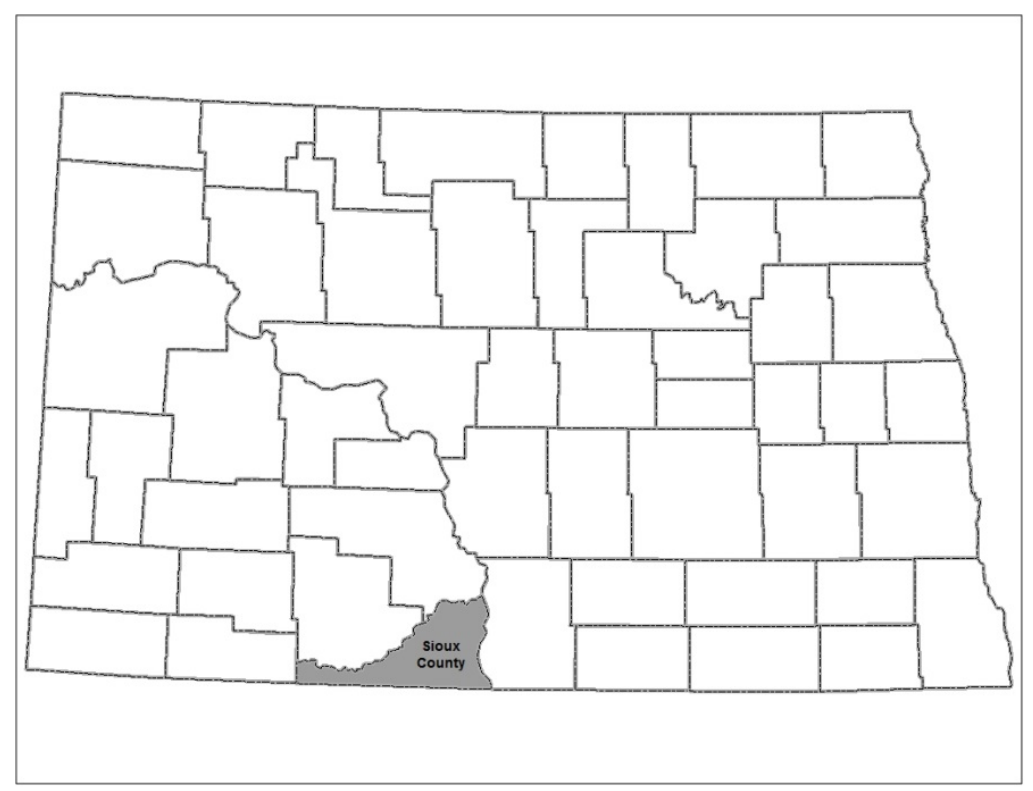

Figure 2.14 Standing Rock Public Transportation - North Dakota Service Area 


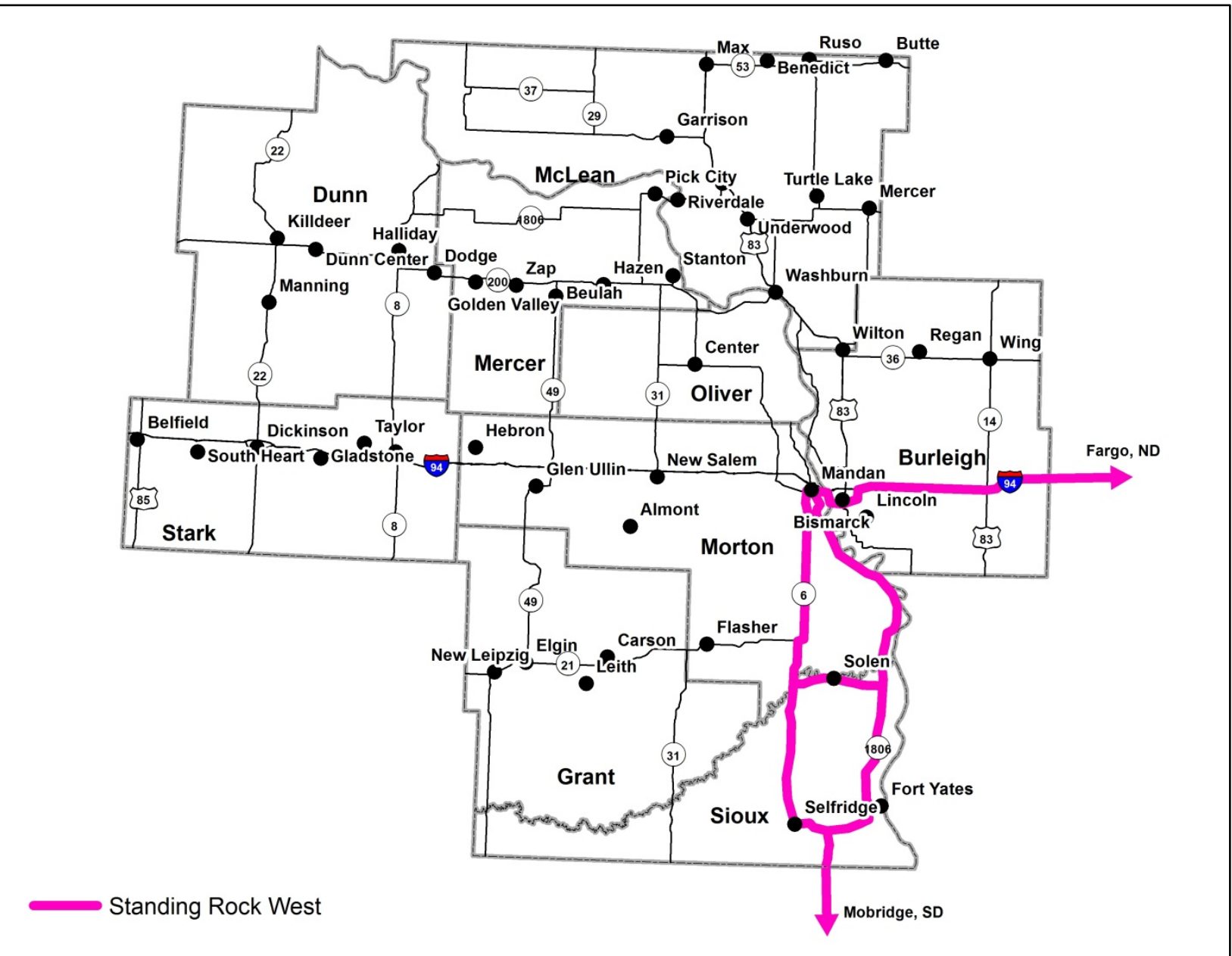

Figure 2.15 Standing Rock Public Transportation - Routes to Regional Centers

SRPT operates 15 vehicles ranging in capacity from 5 to 26 passengers. Nine of its vehicles are handicapped accessible. In North Dakota, in FY 2011, SRPT vehicles traveled 231,551 miles and provided 20,785 one-way rides. The majority of its rides are commuter related. All rides are requested through SRPT's main office in Ft. Yates. SRPT currently coordinates its services with Bis-Man Transit, River Cities Public Transit in Pierre, SD, and the region's intercity bus companies.

Table 2.7 summarizes Standing Rock Public Transportation performance statistics for FY 2007-2011. The summary reflects Standing Rock's operations in both North and South Dakota since many related statistics are not allocated separately between the two states.

As Table 2.7 illustrates, Standing Rock's operations have grown dramatically from 2007 to 2011. Ridership more than tripled, vehicle miles of service increased by $33 \%$, and total operating expenses experienced nearly a two-fold increase. Operating expense per mile increased by $47 \%$, while expenses per passenger trip declined by nearly $37 \%$.

Table 2.7 also reports one-way trips per service area population. In the case of Standing Rock Public Transportation, the service area is defined as all of Sioux County, North Dakota, and Corson County, South Dakota. These two counties had a 2010 estimated population of 8,203. Using 2011 ridership data 
and the most recent population estimate produces a per capita ridership of 2.53 , an increase of $215 \%$ since 2007.

SRPTs operating expenses per hour showed dramatic fluctuations between 2009 and 2011, suggesting that there was an error in the vehicle hours reported for FY 2010. That was not the case, however. SRPT ran experimental mid-day routes in 2010 , which greatly increased its vehicle hours and vehicle miles. That service offering was subsequently discontinued because of low ridership and high operating costs.

Table 2.7 Standing Rock Public Transportation - Financial, Operating, and Performance Trends FY 2007-2011

\begin{tabular}{|c|c|c|c|c|c|c|}
\hline Underlying Data & 2007 & 2008 & 2009 & 2010 & 2011 & $\begin{array}{c}\text { Percent } \\
\text { Change } \\
\text { 2006-2011 }\end{array}$ \\
\hline One-way passenger trips* & 6,686 & 17,434 & 15,604 & 21,952 & 20,785 & $+210.9 \%$ \\
\hline Vehicle revenue miles* & 173,712 & 227,419 & 207,737 & $264,063^{* *}$ & 231,551 & $+33.3 \%$ \\
\hline Vehicle revenue hours* & N.A. & 3,124 & 5,528 & 8,748 & 6,942 & $+122.2 \%$ \\
\hline Service area population & 8,325 & 8,325 & 8,325 & 8,203 & 8,203 & $-1.5 \%$ \\
\hline Operating expenses* & $\$ 420,884 * *$ & $\$ 438,833^{* *}$ & $\$ 617,577 * *$ & $\$ 710,124$ & $\$ 776,611$ & $+84.5 \%$ \\
\hline \multicolumn{7}{|l|}{ Performance Measures } \\
\hline One-way trips/capita & 0.80 & 2.09 & 1.90 & 2.67 & 2.53 & $+215.3 \%$ \\
\hline One-way trips/mile & 0.04 & 0.08 & 0.08 & 0.08 & 0.09 & $+125.0 \%$ \\
\hline One-way trips/hour & N.A. & 5.58 & 3.21 & 2.51 & 2.99 & $-46.4 \%$ \\
\hline Operating expenses/hour & N.A. & $\$ 140.47$ & $\$ 125.52$ & $\$ 81.18$ & $\$ 119.12$ & $-15.2 \%$ \\
\hline Operating expenses/mile & $\$ 2.42$ & $\$ 1.93$ & $\$ 2.97$ & $\$ 2.69$ & $\$ 3.57$ & $+47.5 \%$ \\
\hline $\begin{array}{l}\text { Operating expenses/one- } \\
\text { way trip }\end{array}$ & $\$ 62.95$ & $\$ 25.17$ & $\$ 39.13$ & $\$ 32.35$ & $\$ 39.79$ & $-36.8 \%$ \\
\hline
\end{tabular}

*Source: National Transit Database

**Source: Corrected data provided by operator.

Other than Standing Rock's twice monthly veteran trips to Fargo, its service area does not interface with the service territories of other rural transit services. It is, however, willing to coordinate this service with other operators along the I-94 corridor. Comparable opportunities may exist regarding a similar service that Standing Rock provides to the Veterans Administration Hospital in Sturgis, SD.

\subsection{West River Transit}

Excluding the Bismarck-Mandan metropolitan area, West River Transit operates throughout Burleigh, Grant, McLean, Mercer, Morton, Oliver, and Dunn counties in west central North Dakota. Unlike many rural transit operators in the regions, the provision of transit services is WRT's only function. Its service area is depicted in Figure 2.16. 


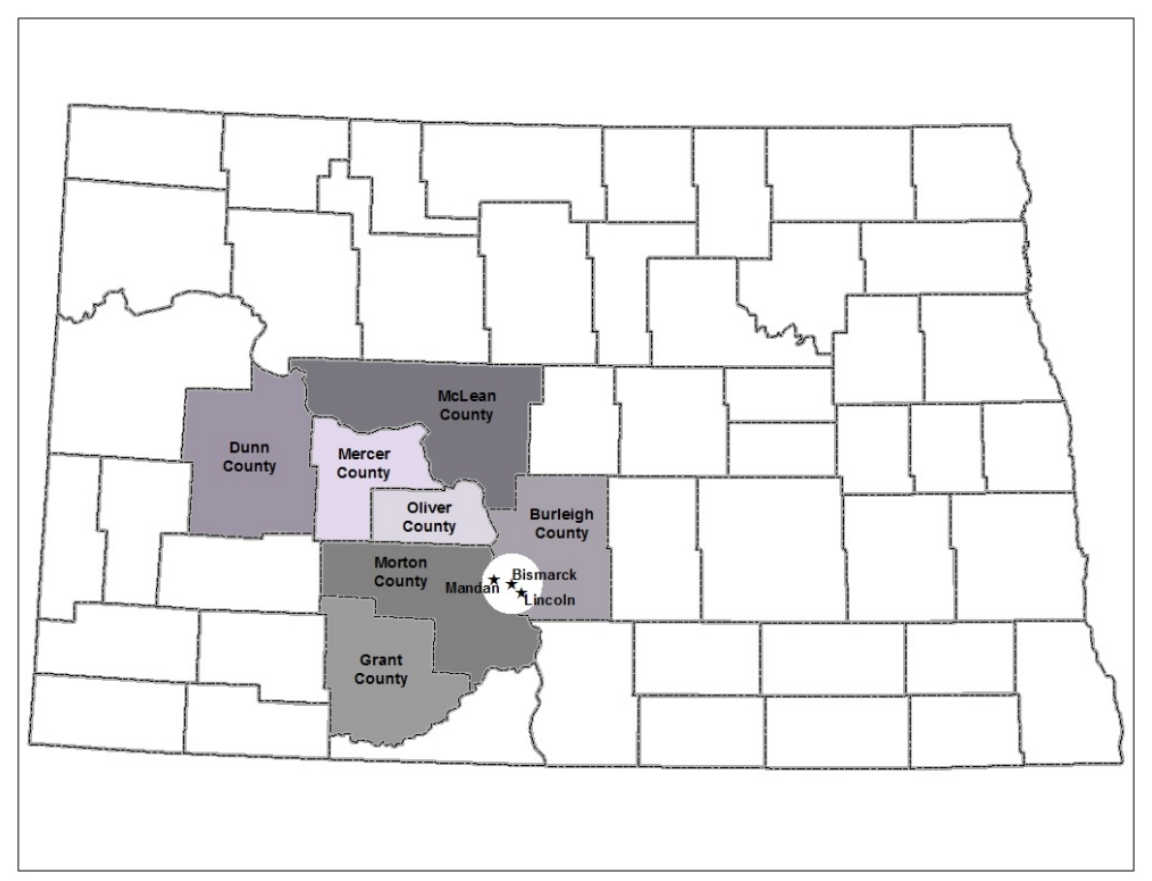

Figure 2.16 West River Transit - Service Area

WRT is a private, nonprofit agency governed by a board of directors made up of representatives from the counties in the service area; the board meets quarterly, and there are no term limits. It also has a separate advisory board made up of representatives from each county in WRT's service area.

WRT's primary funding sources are the federal Section 5311 program, North Dakota's state aid for public transportation program, county senior services mill levy funds from four counties, and other local support. It has two full-time administrative staff members (a director and administrative assistant) and 21 part-time drivers.

WRT provides local demand-response service on scheduled days in 18 communities. Bismarck is a primary destination for many of the cities in the seven-county service area, with some areas receiving service up to three times per week. Some communities in western counties receive service to Dickinson on a monthly basis, while northern counties receive service to Minot.

Local service is provided Monday through Friday. Hours vary by community but generally extend from 7 or8 a.m. to 5 or 6 p.m. Requests for service from small communities to larger hubs for shopping or medical appointments may be made on a same day basis, but riders are encouraged to call a day in advance. West River charges $\$ 2$ for local, roundtrip service. The fare for a 158-mile roundtrip from Beulah to Bismarck is $\$ 11$, or $\$ .070$ per mile. The fare for a 156-mile roundtrip from Beulah to Dickinson is $\$ 11$, or $\$ .071$ per mile. West River's routes to regional centers are illustrated in Figure 2.17. 


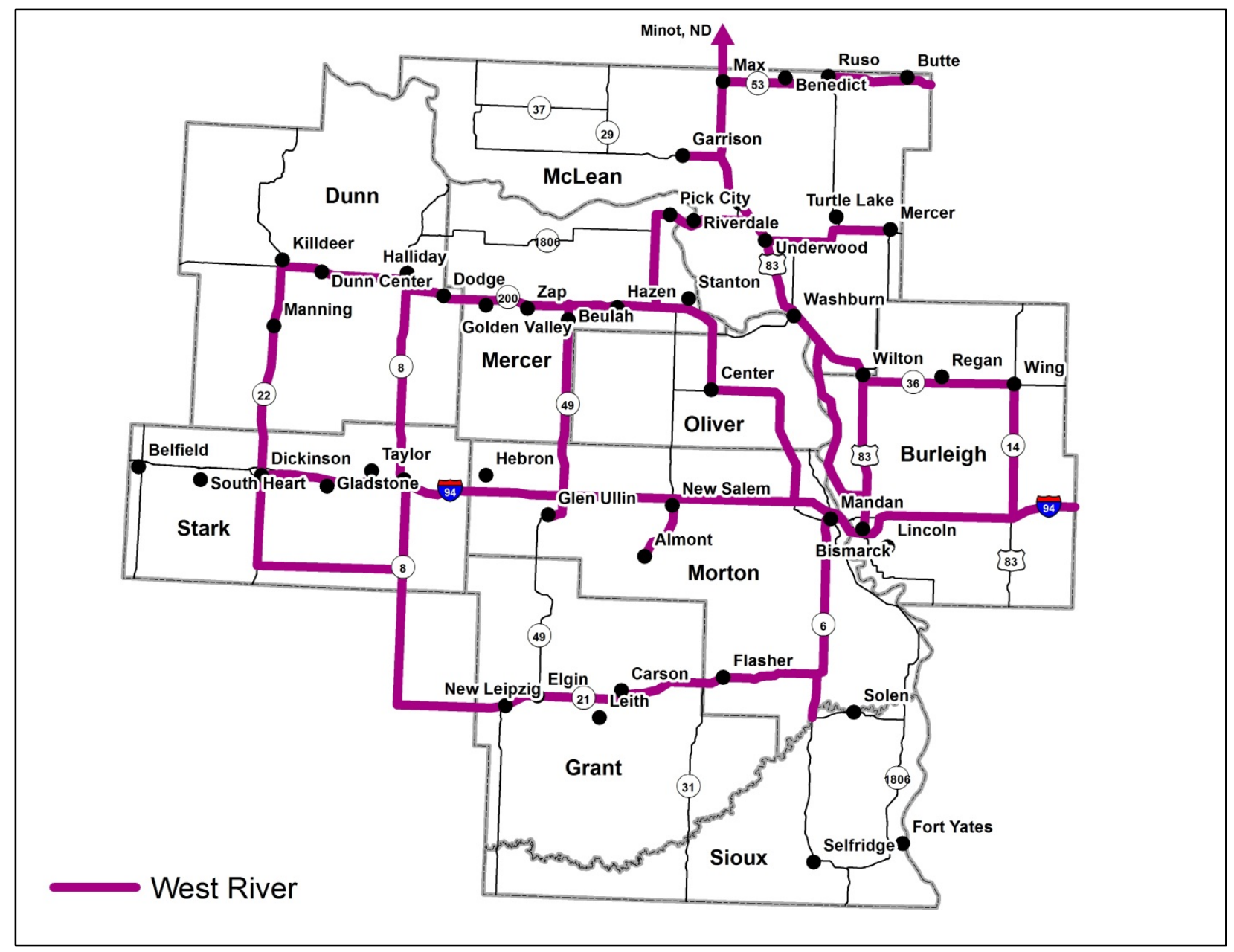

Figure 2.17 West River Transit - Routes to Regional Centers

WRT operates 14 vehicles ranging in size from 7 to 16 passengers; 12 of the 14 vehicles are handicapped accessible. West River provided 27,061 one-way rides in FY 2011 and its vehicles traveled 117,357 miles to provide related service. Riders call WRT's main office in Bismarck or, in some locations, a local driver to request service. West River currently coordinates its services on an informal basis with other transit providers both in and outside the region.

Table 2.8 summarizes West River Transit's performance statistics for FY 2007-2011. As may be noted, ridership increased by nearly $16 \%$ during the five-year period despite a significant drop in population in the service area. WRT's vehicle miles increased by more than $52 \%$ during the five-year period, while operating costs per mile increased by $18 \%$. 
Table 2.8 West River Transit - Financial, Operating, and Performance Trends, FY 2007-2011

\begin{tabular}{|l|r|r|r|r|r|c|}
\hline \multicolumn{1}{|c|}{ Underlying Data } & \multicolumn{2}{c|}{} & \multicolumn{2}{c|}{$\begin{array}{c}\text { Percent } \\
\text { Change } \\
\mathbf{2 0 0 7 - 2 0 1 1}\end{array}$} \\
\hline One-way passenger trips & 23,349 & 33,483 & 33,500 & 26,996 & $27,044 * *$ & $+15.8 \%$ \\
\hline Vehicle revenue miles & 76,991 & 125,023 & 120,944 & 111,940 & 117,354 & $+52.4 \%$ \\
\hline Vehicle revenue hours & N.A. & 9,137 & 8,205 & 8,340 & 7,986 & $-12.6 \%$ \\
\hline Operating expenses & $\$ 251,823$ & $\$ 367,619$ & $\$ 364,303$ & $\$ 379,619$ & $\$ 452,838$ & $+80.0 \%$ \\
\hline Service area population & 44,032 & 44,032 & 44,032 & 44,032 & 30,096 & $-31.6 \%$ \\
\hline & & & & & & \\
\hline \multicolumn{1}{|c|}{ Performance Measures } & & & & & & \\
\hline One-way trips/capita & 0.52 & 0.76 & 0.76 & 0.76 & 0.90 & $+73.1 \%$ \\
\hline One-way trips/mile & 0.30 & 0.27 & 0.28 & 0.30 & 0.23 & $-23.3 \%$ \\
\hline One-way trips/hour & N.A. & 3.66 & 4.08 & 4.01 & 3.39 & $-7.4 \%$ \\
\hline Operating expenses/mile & $\$ 3.27$ & $\$ 2.94$ & $\$ 2.60$ & $\$ 3.39$ & $\$ 3.86$ & $+18.0 \%$ \\
\hline Operating expenses/hour & N.A. & $\$ 40.23$ & $\$ 38.31$ & $\$ 45.52$ & $\$ 56.70$ & $+40.9 \%$ \\
\hline Operating expenses/one-way trip & $\$ 10.79$ & $\$ 10.98$ & $\$ 9.38$ & $\$ 14.06$ & $\$ 16.74$ & $+55.1 \%$ \\
\hline
\end{tabular}

*Source: National Transit Database

**Previously reported data corrected by operator (from 25,212 to 27,044 )

West River Transit's service area is defined as the non-MPO areas of Burleigh and Morton counties and all of Grant, McLean, Mercer, and Oliver Counties. As Table 3.8 indicates, this area experienced a significant decline in population from 2002 to 2010 . This occurrence would presumably contribute to WRT's decline in rides. Conversely, WRT actually achieved a $73 \%$ increase in rides per capita from FY 2007 through FY 2011. Nationally, rural transit systems generate between one and two rides per capita, slightly above the .9 rides generated by WRT.

West River Transit covers a large service area that presents numerous opportunities for coordination with other transit service providers. WRT coordinates its services, particularly with Glen Ullin, Hazen, Dickinson, and Williston Transit. Opportunities do exist, however, for expanded coordination with Glen Ullin and Hazen. Related discussions took place in June and July 2012, as a part of this coordination pilot project. The outcome of those discussions will be discussed in Chapter 3.

\subsection{Composite Routes and Fare Comparisons}

The maps in the preceding sections illustrate each of the service provider's routes to regional centers. Figures 2.18 and 2.19 present a composite view of each region's related routes. As these maps illustrate, there are multiple overlaps in service, each of which may present an opportunity for further coordination. These opportunities will be discussed in Chapter 3.

Note that overlapping or duplicative routes are not necessarily unwarranted. Related vehicles may, for example, be operating on different days and may be operating at passenger capacity. Related determinations cannot be made, however, without further discussions involving personnel from each transit system. Those discussions did take place as a part of this coordination project and will be discussed in the following chapter. 


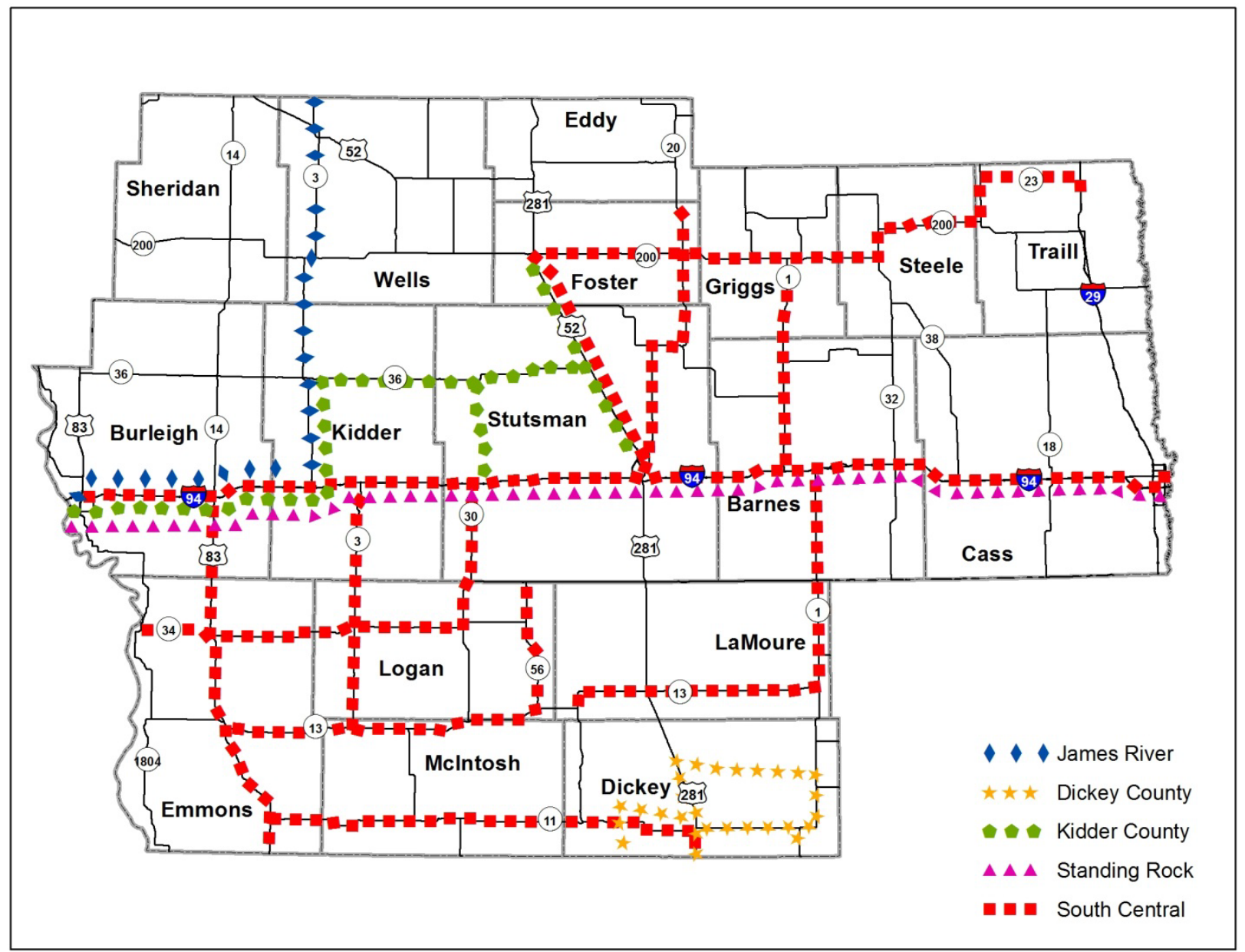

Figure 2.18 South Central Region - Routes to Regional Centers 


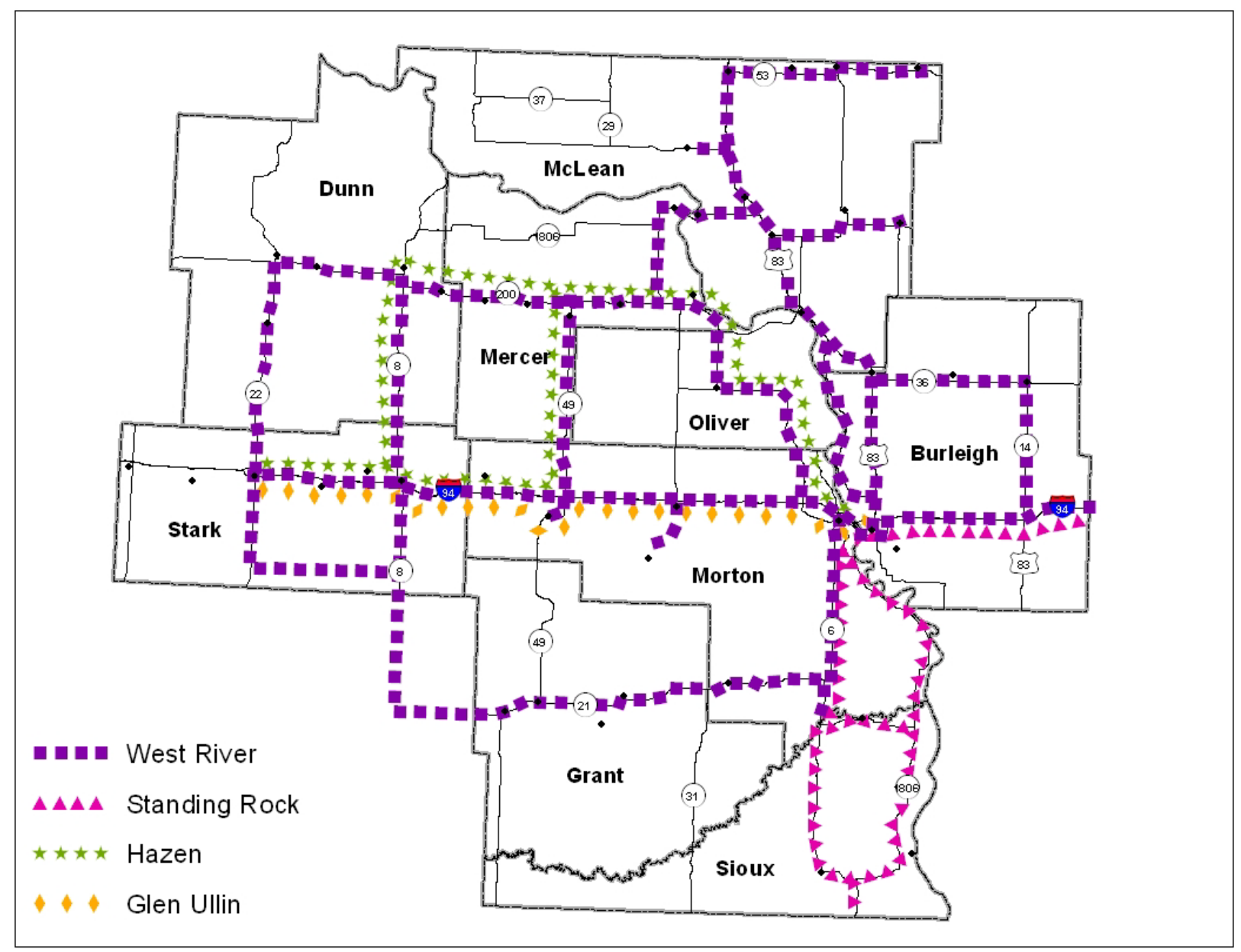

Figure 2.19 West Central Region - Routes to Regional Centers

The preceding sections also presented information regarding each service provider's local and long distance fares. Table 2.9 presents a composite summary of these fares.

As Table 2.9 illustrates, there is a significant difference in the fares charged by the regions' service providers. For example, some operators charge as little as $\$ .50$ for local one-way trips while others charge $\$ 2$ or more. Similarly, long distance fares range from a low of $\$ .037$ per mile to a high of $\$ .175$ per mile. While some variances might be expected, based on varying operating costs, these differences warrant review. Each operator should assess the cost of providing various types of service and should make related fare adjustments to achieve a desired fare recovery ratio.

Significant differences in long distance fares might serve as an impediment to coordination. Patrons in various communities will be unlikely to use the services of another provider if there are significant and detrimental differences in fares. Addressing these fare discrepancies will be one of the topics discussed in Chapter 3. 
Table 2.9 Composite Local and Long Distance Fares

\begin{tabular}{|c|c|c|c|c|c|c|}
\hline & $\begin{array}{c}\text { Local } \\
\text { one-way } \\
\text { trip } \\
\end{array}$ & $\begin{array}{c}\text { Local } \\
\text { round-trip }\end{array}$ & $\begin{array}{l}\text { Round trip } \\
\text { to Bismarck } \\
\text { (per mile) }\end{array}$ & $\begin{array}{l}\text { Round trip } \\
\text { to Dickinson } \\
\text { (per mile) }\end{array}$ & $\begin{array}{l}\text { Round trip } \\
\text { to Aberdeen } \\
\text { (per mile) }\end{array}$ & $\begin{array}{c}\text { Round trip } \\
\text { to Fargo } \\
\text { (per mile) } \\
\end{array}$ \\
\hline $\begin{array}{l}\text { Dickey County } \\
\text { (Oakes) }\end{array}$ & NA & $\$ 1$ & NA & NA & $\begin{array}{c}\$ .125 \\
(\$ 10-80 \text { miles })\end{array}$ & NA \\
\hline Glen Ullin & $\$ .50$ & NA & $\begin{array}{c}\$ .045 \\
(\$ 5-110 \\
\text { miles })\end{array}$ & $\begin{array}{c}\$ .050 \\
(\$ 5-100 \\
\text { miles })\end{array}$ & NA & NA \\
\hline Hazen & $\$ .75$ & NA & $\begin{array}{c}\$ .068 \\
(\$ 10-146 \\
\text { miles })\end{array}$ & $\begin{array}{c}\$ .057 \\
(\$ 10-175 \\
\text { miles })\end{array}$ & NA & NA \\
\hline $\begin{array}{l}\text { James River } \\
\text { (Jamestown) }\end{array}$ & $\$ 2.50$ & NA & $\begin{array}{c}\$ .175 \\
(\$ 35-200 \\
\text { miles })\end{array}$ & NA & NA & $\begin{array}{c}\$ .175 \\
(\$ 35-200 \\
\text { miles })\end{array}$ \\
\hline $\begin{array}{l}\text { Kidder County } \\
\text { (Steele) }\end{array}$ & $\$ .50$ & NA & $\begin{array}{c}\$ .089 \\
(\$ 8-90 \\
\text { miles })\end{array}$ & NA & NA & NA \\
\hline $\begin{array}{l}\text { South Central } \\
\text { (Valley City) }\end{array}$ & $\$ 2$ & NA & $\begin{array}{c}\$ .037 \\
(\$ 10-270 \\
\text { miles })\end{array}$ & NA & $\begin{array}{c}\$ .08 \\
(\$ 13-162 \\
\text { miles })\end{array}$ & $\begin{array}{c}\$ .08 \\
(\$ 10-124 \\
\text { miles) }\end{array}$ \\
\hline $\begin{array}{l}\text { Standing Rock } \\
\text { (Ft. Yates) }\end{array}$ & $\$ 1$ & NA & $\begin{array}{c}\$ .074 \\
(\$ 10-136 \\
\text { miles })\end{array}$ & NA & NA & $\begin{array}{c}\$ .10 \\
(\$ 53-524 \\
\text { miles })\end{array}$ \\
\hline $\begin{array}{l}\text { Wells- } \\
\text { Sheridan } \\
\text { (Harvey) }\end{array}$ & $\$ 1.50$ & NA & $\begin{array}{c}\$ .136 \\
(\$ 30-220 \\
\text { miles })\end{array}$ & NA & NA & NA \\
\hline $\begin{array}{l}\text { West River } \\
\text { (Beulah) }\end{array}$ & NA & $\$ 2$ & $\begin{array}{c}\$ .070 \\
\left(\begin{array}{c}\$ 11-158 \\
\text { miles })\end{array}\right. \\
\end{array}$ & $\begin{array}{c}\$ .071 \\
\left(\begin{array}{c}\$ 11-156 \\
\text { miles })\end{array}\right. \\
\end{array}$ & NA & NA \\
\hline
\end{tabular}

In November 2011, at the request of NDDOT's Transit Section, SURTC conducted a cost allocation workshop for the state's transit service providers. The intent of the workshop was to equip service providers with the insights and tools required to determine the true costs associated with providing each of their various types of service (local demand-response services, intercity services, contract services, proposed routes, etc.). Knowing associated costs is essential if an operator is going to establish an equitable fare structure. It is also essential if operators are going to work together to establish fare structures that facilitate coordination. Related discussions and actions will be discussed in Chapter 3 .

\subsection{NDDOT Transit Staffing}

NDDOT's transit staff consists of three full-time and two part-time employees. Among other things, staff workloads are a function of the number of federal programs being administered, the amount of state and federal funding being managed, and the number of transit systems in the state.

As indicated in Table 2.10, NDDOT's staffing level is very comparable to other rural states in the Upper Midwest. NDDOT's transit staff manages an annual budget of approximately $\$ 7.0$ million, which is about average for the five states listed in Table 2.10. With 31 rural transit systems to oversee and related contracts to administer, North Dakota is slightly below the five-state average. All things considered, the workload and the size of NDDOT's transit staff appear to be comparable to those of nearby rural states. 
Table 2.10 State Transit Staffing and Budgets

\begin{tabular}{|l|c|l|c|}
\hline \multicolumn{1}{|c|}{ State } & $\begin{array}{c}\text { Annual State and } \\
\text { Federal Funding } \\
\text { (Millions) 2012 }\end{array}$ & \multicolumn{1}{|c|}{ Staff Size } & $\begin{array}{c}\text { Number of 5311 } \\
\text { Transit Systems }\end{array}$ \\
\hline Montana & $\$ 10.3$ & 4 FTE & 41 \\
\hline Nebraska & $\$ 7.4$ & 4 FTE & 61 \\
\hline North Dakota & $\$ 7.0$ & 3 FTE \& 2 PT & 31 \\
\hline South Dakota & $\$ 10.0$ & 2.5 FTE & 22 \\
\hline Wyoming & $\$ 5.0$ & 4.0 FTE & 41 \\
\hline Average & $\$ 7.9$ & 3.5 FTE \& .4 PT & 39 \\
\hline
\end{tabular}




\section{PROJECT TASKS, ACHIEVEMENTS, AND ONGOING ACTIVITIES}

This coordination project was designed to pursue implementation of many of the recommendations set forth in the 2010 Public Transit Regional Coordination Pilot Projects in North Dakota report. NDDOT contracted with SURTC to prepare the 2010 report to assist it with the implementation of the provisions of S.B. No 2223. This project's scope of work, as outlined earlier in Figure 1.2, spanned 15 months and was divided into 5 phases and 17 related tasks. Work on a majority of the tasks proceeded simultaneously.

This chapter identifies each of the project's phases and corresponding tasks, discusses work that was done on each task, and summarizes related accomplishments and ongoing activities. As these presentations illustrate, some of this project's tasks related specifically to transit operations in the two pilot regions, while others had implications for and benefited all of North Dakota's rural public transit systems. The impacts of many of the related efforts may be recognizable almost immediately, while others may not be ascertainable for several months, or even longer.

\subsection{Phase I - Enhance Local Coordination}

Phase I included two subtasks, both of which relate to the formation and operations of local planning/advisory committees. Task I-1involved the evaluation of each operator's local governing board, and Task I-2 involved the reconfiguration of these boards, if necessary, to enhance a local, transit-related presence on the boards. Related actions by each local transit system were voluntary. These two tasks are discussed in greater detail in the following subsections.

\subsubsection{Evaluate Local Committees}

Many of North Dakota's rural transit services started out as senior citizen busing programs. While they now provide services to the public, many have continued to have governing boards comprised largely of senior citizens who oversee not only transit, but also numerous senior programs such as home delivered meals, the operations of local senior centers, etc.

The 2010 coordination report recommended that NDDOT require all entities that received federal or state transit monies administered by the department have a governing board or subsidiary committee that included human service/social service agencies, transit users/advocates, businesses/local government/economic development organizations, and other appropriate entities. The intent of this recommendation was to ensure that each transit system has a broad range of perspectives available to help identify local mobility needs, to oversee the creation of service options that are responsive to those needs, and to coordinate services with those provided by commercial and other publicly-supported transit operators.

In October 2011, shortly after the initiation of this project, SURTC researchers and NDDOT's transit staff conducted on-site meetings with each of the regions' eight rural transit operators. These meetings were used to inform program managers on the scope of the project and to collect updated information on each operation, including the existence and functions of local governing boards and/or transit advisory committees.

Prior to the 2010 coordination study, Standing Rock Public Transportation was the only one of the regions' eight rural transit operators that had a local transit advisory committee. The October 2011 inventory of local advisory committees indicated that Hazen Busing and West River Transit had also established local committees. The Hazen committee reports to Hazen's city council, while West River 
Transit's committee reports to the board of directors. Neither committee had a set of bylaws which clearly outlined committee functions, membership, etc.

\subsubsection{Establish/Reconfigure Local Advisory Committees}

To further encourage local operators to establish local transit advisory committees and to lend clarity to those that already exist, SURTC researchers worked with NDDOT transit staff to draft guidelines and template bylaws regarding local advisory boards. These guidelines outlined related board functions and identified the types of entities that should be represented on local boards.

These guidelines and template bylaws, a copy of which are presented in Appendix A, were presented to all the state's transit service providers on January 25, 2012, at a NDDOT quarterly transit meeting. NDDOT's Transit Section encouraged the corresponding enactment by not only the transit operators in the two pilot regions, but also by transit operators across the state. This action is especially relevant given the fact that the majority of the state's rural transit systems are multi-service providers - they evolved out of local senior citizen programs and have a wide variety of functions, one of which is transit. Establishing a local advisory board whose sole function is transit-related would facilitate local need identification and coordination activities.

Glen Ullin's city council formalized its transit advisory committee in early 2012 by adopting the recommended bylaws and expanding the committee's membership. Kidder County is also working to establish a transit advisory board. NDDOT's Transit Section encourages all multi-service providers to establish local transit advisory committees.

\subsection{Phase II - Enhance Regional Coordination}

While Phase I tasks focused on facilitating communications and coordination at the local level to help identify and satisfy local personal mobility need, Phase II and its four corresponding tasks were aimed at creating an awareness of available transit services among the regions' service providers. This awareness regarding each other's services, along with increased uniformity on rider policies, operating hours, fares, etc., was deemed an important starting point for subsequent discussions regarding region-wide coordination. The following subsections describe corresponding efforts that were taken to enhance regional coordination via increased operator awareness of each other's operations and to solicit operator input concerning potential long-term functions of regional coordination administrators and possible funding sources.

\subsubsection{Quarterly Meetings with Operators}

While all the regions' operators had a general understanding of each other's operations, the scope of work required that quarterly meetings of all the regions' operators be held to further enhance awareness and to facilitate coordination. Whenever possible, these meetings were to be held in conjunction with other scheduled meetings, minimizing the amount of time that operators had to be away from their office.

The prescribed quarterly meetings were held throughout the project. The first meeting was held on November 17, 2011, and provided operators with a broad overview of the project's objectives and related timelines. A key part of this meeting involved each operator giving a presentation on their system's routes and fares.

These presentations resulted in the creation on a composite route map for each region, copies of which were presented earlier in Figures 2.18 and 2.19. These maps and the fare comparison grid that was 
presented in Table 2.9 became a focal point for further discussions regarding service duplication and possible route and schedule restructuring.

The agendas for other quarterly meetings included presentations on topics such as website design options, services that are available from urban area mobility managers, and the workings of local transit advisory committees. The quarterly meetings were also used to solicit operator input regarding their perceptions of regional coordination (need, duties, funding, etc.). Related feedback will be discussed further in Subsection 3.2.4.

\subsubsection{Increase Operator Awareness of Each Other's Operations}

In addition to quarterly, face-to-face meetings, SURTC researchers also used e-mail correspondence to help create operator awareness of each other's operations. For example, in early December 2011, SURTC asked each of the regions' operators to complete a coordination self-assessment survey. This survey asked operators to identify:

- Existing processes for identifying and responding to local personal mobility needs and proposed actions to enhance these processes

- Other transit operators that services are currently coordinated with and related initiatives that are currently in place

- Opportunities for further coordination and proposed modifications to implement related changes

Survey responses were compiled and disseminated to all the regions' providers, along with the composite route maps and the fare comparison grid discussed earlier. Related responses are presented in Appendix $\mathrm{B}$ and will be discussed further in Subsection 3.2.6. These responses helped all the regions' operators become better informed on the services provided by other operators and set the stage for one-on-one discussions regarding opportunities for further coordination.

As will be discussed in subsequent subsections, SURTC researchers worked with each of the regions' transit systems and NDDOT's transit staff to create or enhance local transit websites. In addition to making related information readily available to riders, caregivers, etc., it also gave other transit managers access to current information regarding their regional counterparts.

Chapter 2 of this report presented a comprehensive overview of each of the region's rural transit systems. To help ensure the accuracy of related information, a draft of that chapter was sent to all the regions' transit managers for their review and comment. In addition to facilitating accuracy, a review of the entire chapter helped further educate managers on the scope of services provided by each of the other operators in the two pilot regions.

\subsubsection{Seek Uniformity in Operator Policies, Services, and Practices}

Publicly-funded transit services are required to adopt policies governing matters such as drug and alcohol training and nondiscrimination. All of the regions' operators have the required policies in place.

Operators routinely find that local circumstances require the adoption of additional policies. These policies may involve things such as wait times for passengers, allowable carry-on packages, service cancellations due to inclement weather, etc.

To facilitate the adoption of policies that are reflective of sound industry practices and to reduce related drafting burdens on system administrators, SURTC compiled a set of template policies based on industry best practices. These policies, as identified in Table 3.1, are available, not only to the regions' operators, 
but also to operators around the state and country. These templates are posted on SURTC's website (www.surtc.org) and have been made available to NDDOT's Transit Section for possible inclusion on the department's transit website.

Table 3.1 Policy Templates

\begin{tabular}{|c|c|}
\hline Policy Title & Subject \\
\hline Advisory Boards & Sample policy regarding local advisory boards \\
\hline ADA Sample Policy & Providing services to people with disabilities \\
\hline Attendance Policy & Acceptable employee work schedules \\
\hline Bus Delivery Inspection Checklist & New bus inspection and receipt form \\
\hline Bus Driver Behavior Policy & Driver responsibilities \\
\hline Cell Phone Usage & Driver use of cell phones \\
\hline Civil Rights Policy - Title VI & Federal compliance civil rights \\
\hline Coordination Self-Assessment Form & Operator self-assessment form \\
\hline Dangerous Person Form & Driver reporting form regarding dangerous persons \\
\hline Driver Handbook & Miscellaneous driver/system policies \\
\hline Driver Physical Form & CDL medical examination forms \\
\hline Driver Review Forms & Driver performance review \\
\hline Employee Annual Performance Review Form & Employer performance annual review form \\
\hline Employment Applications & Sample job application forms \\
\hline General Public Service Policy & Mission statement, general policies, etc. \\
\hline Harassment Policy & Verbal and physical abuse and work environment \\
\hline Hostage/Shooter Situation Form & Reporting form regarding hostages/shooters \\
\hline Interview Questions & Sample interview questions \\
\hline No Show Policy & Penalties for rider no-shows \\
\hline Oxygen Tank Transport & Types of tanks and proper securement \\
\hline Passenger Assistance Evaluation Form & Driver review (internal) \\
\hline Passenger Behavior & Acceptable rider behavior and related penalties \\
\hline Passenger Bill of Rights & Reasonable client expectations of transit system \\
\hline Policy Receipt Form & Employee acknowledgement of receipt of policies \\
\hline Rider's Guide & System policies, schedules, fares, etc. \\
\hline Safe Ride Evaluation Form & Driver performance review \\
\hline Service Animals & Policy regarding transporting service animals \\
\hline Service Reliability Forms & Reasonable service expectations \\
\hline Sexual Abuse Policy & Appropriate employees behavior \\
\hline Sexual Harassment & Appropriate behavior and recourses \\
\hline Shared Vehicle Guidelines & Sharing vehicles between transit operators \\
\hline Social Networking Policy & Acceptable cell phone, computer, and Internet use \\
\hline Transit Vehicle Accident Form & Accident report forms \\
\hline
\end{tabular}

These policies are available on the Small Urban \& Rural Transit Center website at www.surtc.org and have been taken from other transit systems or transit related organizations. None are intended to be legally binding and should be reviewed by local legal entities and adopted by the governing board of any organization that uses them.

As a part of this coordination project, SURTC researchers worked with NDDOT transit staff to develop a template rider's guide that operators may use to publicize information concerning their operations and policies. Each of the various sections of this template rider's guide is reflective of industry best practices. Topics covered include hours of operation, reservation requirements, fares, trip cancellations, food and beverages on vehicles, pets, seat belt usage, filing complaints, prohibited behavior, and a discrimination statement. A copy of this template is presented in Appendix C. 
Most of the regions' operators decided to adopt this template riders' guide, with various modifications specific to their system. The final products were typically printed and made available to current and potential riders. These guides were also made a part of operator websites. In some instances, pronouncements made in an operator's rider's guide may require the adoption of a related policy.

Perhaps the most notable lack of uniformity regarding rural transit systems involved fare structures. As indicated earlier in Table 2.9, local one-way fares within the two pilot regions vary from $\$ .50$ to $\$ 2.50$, and long distance fares over similar routes vary from less than $\$ 0.04$ per mile to $\$ 0.175$ per mile.

On November 16-17, 2011, under a separate contract with NDDOT, SURTC conducted a cost allocation workshop that was mandatory for all of North Dakota's rural transit operators. The intent of the workshop was to help operators determine the costs associated with each segment of their existing operations and to be able to estimate costs associated with possible service modifications.

According to 2010 National Transit Database (NTD) statistics, rural demand-response transit systems around the country achieved an aggregate farebox recovery ratio of 7\%. A review of NTD data indicates that federally funded operators in North Dakota's two pilot regions achieved ratios ranging from $8 \%$ to 24\%. In North Dakota, NDDOT's Transit Section has advised rural transit operators that they should strive for fares that recover at least $10 \%$ of related costs.

Vast differences in fares discourage effective coordination, given the fact that passengers will be reluctant to use another operator's services if its fares are significantly higher. The regions' transit managers point out, however, that their local governing boards are reluctant to make drastic changes to existing fare structures. Those with higher fares may need related revenue to cover costs, while those with lower fares may feel that local patrons simply are unable to afford fare increases.

Ultimately, NDDOT's Transit Section may have to find additional ways to further encourage local operators to revise their fares to make them more reflective of current costs and to narrow gaps with neighboring operators in order to further facilitate coordination. Local transit managers may, in fact, welcome such encouragement since it would put them in a better position to approach their governing boards with recommendations concerning fare adjustments.

\subsubsection{Identify Long-term Coordinator Functions}

In early July 2012, SURTC researchers sent the regions' transit managers an e-mail which posed a series of questions regarding the current coordination project. Questions included topics such as perceived achievements, burdens imposed by the project, future coordination-related activities, possible duties of a regional coordinator, and sources of funding for future coordination activities. The managers were advised that their related responses would be the primary focus of the quarterly NDDOT transit meeting scheduled for July 25, 2012. A copy the questions posed and manager responses are presented in Appendix D.

During discussions at the July $25^{\text {th }}$ meeting, some operators voiced the opinion that regional transit coordinators were unnecessary. One operator voiced the opposite opinion, contending that many of the achievements that all the operators benefitted from via this project might be undone if there is not someone to provide continuing initiative, support, and oversight. Related duties might include conducting quarterly coordination meetings with the regions' operators, monitoring operators' routes and fares, looking for ways to further enhance coordination, working with each operator's advisory board to monitor local mobility needs and developing responsive transit service, and helping operators with possible policy updates. Operators opposed to regional coordinator staffing reiterated their opposition at a regional meeting held on October 24, 2012. 
Draft copies of the final report were sent to transit managers in the two pilot regions on November 1, 2012, and to the state's other transit managers on November 13, 2013. Three mangers provided written comments. Their input is presented in the final pages of Appendix D. No comments were received from the state's other 29 transit managers.

\subsection{Phase III - Increase Public Awareness of Available Services}

Having access to information regarding the availability and scope of local transit services is crucial to a wide variety of interests. These interests include riders, potential riders, caregivers of current and potential users (adult children of senior citizens, social service advocates, etc.), other transit operators, mobility managers, regional transit coordinators, and community planners. The tasks involved with Phase III of this project were designed to increase both access to information concerning rural transit services in the two pilot regions and the quality of that information. These tasks and related achievements are discussed in the following subsections.

\subsubsection{Create/Enhance Operator Websites}

An inventory of the web presence of the regions' eight rural transit providers indicated that a small number had fairly comprehensive websites. Others had websites, but the sites had very little information, or were very outdated.

It was deemed important that all the regions' operators have comprehensive and up-to-date websites. SURTC's role in fulfilling this task was to work with operators to update existing websites or, if necessary, create entirely new websites for all the regions' operators. This task also had to result in sites that were easy to maintain and inexpensive to operate. This task was outlined to operators at the quarterly NDDOT transit meeting on November 17, 2011.

On January 9, 2012, SURTC sent the regions' transit managers an e-mail which identified eight rural transit websites from around the country that had been identified as being exemplary because of their design and/or content. The managers were asked to look at these sites and to identify features that they would like to see in their site. Related discussions took place at the quarterly NDDOT transit meeting on January 25, 2012.

It was decided that SURTC would build local operator sites using a web builder program that was available through the National Rural Transportation Assistance Program (National RTAP). The program was designed specifically for transit organizations, was free to operate, and maintenance service was provided.

Using this web builder program, SURTC personnel presented an initial template design at the January 25, 2012, quarterly NDDOT transit meeting. Based on feedback received by operators, a more refined template was prepared using South Central Transit Network as the test operator. Features of the resulting site included a homepage map of the operator's service area; the operator's logo and pictures of agency vehicles; links to information on service hours, routes, fares, etc.; a newly developed rider's guide; various operator policies; and links to other transit-related entities such as NDDOT (which then gave users information on all of North Dakota's other transit operators, commercial bus companies, and local taxi services).

The regions' operators were highly satisfied with the South Central template and work commenced to develop similar sites for Dickey County, James River, Hazen, and Glen Ullin. West River Transit decided to update its own site. SURTC was asked to review draft versions of West River's site and to 
provide related suggestions. Standing Rock Public Transit took similar actions using personnel from Sitting Bull College, its parent organization. Kidder County decided to create its own new site using a local contractor. SURTC provided the contractor with a copy of the template site and provided related input regarding Kidder County's final product. Given the lack of necessary local input, no work was done on Glen Ullin's site, which is currently a part of the city's website.

Ultimately, seven of the region's eight rural transit operators utilized the web builder services offered by SURTC as a part of this project and have new or renovated websites with comprehensive information on available services. Operators should remain vigilant to keep their sites current.

On July 14, 2012, NDDOT's Transit Section offered a web builder training program to all of the state's transit services. The workshop was conducted by National RTAP and used the same web builder program that SURTC used to create new websites for the regions' transit services. This training should be useful as the regions' transit managers strive to keep their websites comprehensive and current.

\subsubsection{Enhance NDDOT Transit Website}

It is vital that NDDOT have a current and comprehensive website regarding not only local transit service, but also other personal mobility options such as intercity bus services and local taxi operators. It is also helpful if transit industry personnel can have quick access to various application and reporting forms, agency policies, newsletters, etc. via the department's website.

With these points in mind, SURTC researchers worked with NDDOT's Transit Section staff and website personnel to give transit a more prominent presence on the agency's homepage and to make all other related information available with only a few clicks on a mouse.

The initial change involved relabeling "Transit" on NDDOT's homepage to "Bus, Transit, and Taxi Services." This identifier is more all-inclusive and gives users a clearer idea of what information is available via that portal.

Upon clicking on this link, users are taken to a page that listed four selection options:

- Local Bus and Transit Services

- Taxi Services

- Intercity Bus Services

- Transit Operator Forms and Newsletters

The first three of these options relate specifically to existing personal mobility services, while the fourth is intended to provide transit operators with ready access to information regarding grant management, compliance requirements, etc.

The "Local Bus and Transit" link takes users to a North Dakota map which identified all 53 counties. The page also includes lists of the state's counties and largest cities. Users can click on the map or a city or county from the corresponding list and then be taken to a list of all available local bus and transit services that operate in that locale, along with related contact information and, if available, a link to that service's website.

Clicking on "Taxi Services" takes users to a map of the state which identifies cities that have local taxi service, along with related contact information for each corresponding operator. Clicking on the "Intercity Bus Services" link takes users to a map which identifies the routes of all available intercity bus services, along with contact information for each operator. 
During this redesign process, it was determined that the North Dakota Division of Tourism also provides similar information via its website. A review of that site revealed that its contents were sometimes out-ofdate and not as comprehensive as NDDOT's redesigned site. It is recommended that NDDOT's transit staff contact Tourism and recommend that its site simply provide a link to the NDDOT site, thereby eliminating the need to maintain its own site and helping ensure that its users are given accurate information.

\subsubsection{Create Additional Mechanisms to Publicize Transit Services}

Phase I discussions with each of the regions' eight rural operators revealed that local transit systems use a variety of mechanisms to publicized available services and schedules. These mechanisms include: newspaper advertisements, radio announcements, promotional posters and flyers, direct mailings, church bulletin inserts, website postings, personal presentations to local agencies and organizations, etc. Each operator tailors its presentations to the communities served.

It was also determined that statewide promotional efforts may help reach broader segments of the population and help dispel the commonly held belief that transit services are only for elderly and disabled individuals vs. the general public. Related efforts might include public service announcements and general information pieces, while others might help create public awareness by promoting special events such a National Public Transit Week.

To help NDDOT's Transit Section identify possible promotional options, both local and statewide, SURTC researchers compiled information on transit-publicizing initiatives that have been used successfully by local transit operators and other states. Related materials have been posted on SURTC's website (www.surtc.org) and have been made available to NDDOT's Transit Section for possible inclusion on the department's transit website. Several other promotional initiatives are presented in the federally funded Transit Cooperative Research Program report No. 50 - Low Cost and Cost-Effective Marketing Techniques for Public Transit Agencies. A link to this report is also available on SURTC's website.

\subsection{Phase IV - Monitor Performance, Establish Uniform Standards, Develop Coordination Budgets, and Work with Mobility Managers to Facilitate Further Coordination}

Phase IV of this project was a conglomeration of tasks, some of which related to ongoing service provider operations, some that involved ultimate recommendations, and others that involved project management. The following subsections discuss each of Phase IV's six tasks.

\subsubsection{Use Performance Measures to Track Operations}

By industry definition, performance measures use operator statistics to measure the attainment of goals related to system utilization, operating efficiencies, and program effectiveness. Related measures specific to each of the regions' eight rural transit operators were presented in Chapter 2. These measures and underlying operating statistics should be compiled and monitored on a regular basis by both individual operators and NDDOT's transit staff to determine if individual service providers are operating effectively and efficiently. Findings should also be presented to and analyzed by each operator's board of directors, and related goals should be established regarding future operations. 
NDDOT's transit staff and SURTC researchers also worked to identify measures that might be used to monitor operators' service reliability and operational impacts of coordination. This collaborative effort helped identify 10 related measures, each of which is described in Table 3.2.

As Table 3.3 indicates, several of the listed measures required action by SURTC to establish benchmark levels of service reliability and/or impacts of coordination. Long-term measurements and monitoring are, however, the responsibility of NDDOT's Transit Section, with related information being supplied by individual service providers.

To assess current levels of service reliability, SURTC sent the regions' rural transit managers a questionnaire on April 17, 2012, and asked a series of questions regarding actual vs. scheduled pick-up times and service cancellations related to an insufficient number of riders, inclement weather, or vehicle breakdowns. Operator responses reflected a wide range of operating standards, few related policies, and sporadic monitoring of related occurrences.

Based on these findings, SURTC researchers worked with NDDOT's transit staff to draft service reliability guidelines that could be used to promote uniform standards and operator policies. These guidelines address issues such as acceptable performance for scheduled vs. actual passenger pick-up times, and internal decision making regarding the cancellation of long-distance trips due to low rider numbers, inclement weather, or vehicle breakdowns, and the recording and reporting of related cancellations.

A corresponding template was also developed to make it easier for operators to establish their own internal policies regarding service reliability. These guidelines and the template policy, copies of which are presented in Appendix E, were discussed with NDDOT's transit staff at a regularly scheduled semimonthly status update meeting on June 4, 2012. NDDOT's Transit Section may want to present these guidelines to all North Dakota transit operators, thereby, encouraging all service providers to establish policies, standards, and operating procedures regarding service reliability.

\subsubsection{Establish Uniform Operating Standards and Policies}

This task overlaps with the task outlined earlier in Subsection 3.2.2 (Seek Uniformity in Operator Policies, Services, and Practices). As discussed in that subsection, SURTC developed a comprehensive library of policies that reflect industry best practices on a wide range of operational topics. This library will hopefully prove to be a valuable resource for rural operators that are in need of policies to address various issues that arise regarding their local operations.

This library also includes guidelines that SURTC prepared in conjunction with NDDOT's transit staff during the course of this project. These guidelines involve the creation and operations of local transit advisory boards, service reliability, and insurance issues related to shared transit vehicles. 
Table 3.2 Measures of Service Reliability and Operational Impacts of Coordination

\begin{tabular}{|c|c|c|c|c|}
\hline & Description & $\begin{array}{c}\text { SURTC } \\
\text { Responsibility }\end{array}$ & $\begin{array}{c}\text { NDDOT } \\
\text { Responsibility }\end{array}$ & $\begin{array}{c}\text { Operator } \\
\text { Responsibility }\end{array}$ \\
\hline Measure 1 & $\begin{array}{l}\text { Ridesharing - vehicles } \\
\text { concurrently available } \\
\text { for use by multiple } \\
\text { funding sources }\end{array}$ & $\begin{array}{l}\text { Survey operators to } \\
\text { identify services } \\
\text { that are not multi- } \\
\text { purpose/multi- } \\
\text { funded }\end{array}$ & $\begin{array}{l}\text { On an ongoing basis, } \\
\text { require that operators } \\
\text { report when service } \\
\text { are not available to } \\
\text { general public }\end{array}$ & $\begin{array}{l}\text { Record and report } \\
\text { related occurrences }\end{array}$ \\
\hline Measure 2 & $\begin{array}{l}\text { Coordination-related } \\
\text { route consolidations }\end{array}$ & $\begin{array}{l}\text { Record initial } \\
\text { occurrences in } \\
\text { project report }\end{array}$ & $\begin{array}{l}\text { On an ongoing basis, } \\
\text { require that operators } \\
\text { report related } \\
\text { occurrences }\end{array}$ & $\begin{array}{l}\text { Record and report } \\
\text { related occurrences }\end{array}$ \\
\hline Measure 3 & $\begin{array}{l}\text { Service increases made } \\
\text { possible by } \\
\text { consolidations }\end{array}$ & $\begin{array}{l}\text { Record initial } \\
\text { occurrences in } \\
\text { project report }\end{array}$ & $\begin{array}{l}\text { On an ongoing basis, } \\
\text { require that operators } \\
\text { report related } \\
\text { occurrences }\end{array}$ & $\begin{array}{l}\text { Record and report } \\
\text { related occurrences }\end{array}$ \\
\hline Measure 4 & On time performance & $\begin{array}{l}\text { Identify industry } \\
\text { standard; develop } \\
\text { related NDDOT } \\
\text { guidelines }\end{array}$ & $\begin{array}{l}\text { Prescribe standard } \\
\text { and, on an ongoing } \\
\text { basis, require that } \\
\text { operators report } \\
\text { related performance }\end{array}$ & $\begin{array}{l}\text { Record and report } \\
\text { related performance }\end{array}$ \\
\hline Measure 5 & $\begin{array}{l}\text { Reliability - routes } \\
\text { operated as scheduled }\end{array}$ & $\begin{array}{l}\text { Draft related } \\
\text { procedural } \\
\text { guidelines }\end{array}$ & $\begin{array}{l}\text { Prescribe standard } \\
\text { and, on an ongoing } \\
\text { basis, require that } \\
\text { operators report } \\
\text { related occurrences }\end{array}$ & $\begin{array}{l}\text { Record and report } \\
\text { related occurrences }\end{array}$ \\
\hline Measure 6 & $\begin{array}{l}\text { Rider transfers within } \\
\text { system }\end{array}$ & No action required & $\begin{array}{l}\text { On an ongoing basis, } \\
\text { require that operators } \\
\text { report related } \\
\text { occurrences }\end{array}$ & $\begin{array}{l}\text { Record and report } \\
\text { related occurrences }\end{array}$ \\
\hline Measure 7 & $\begin{array}{l}\text { Rider transfers from } \\
\text { other operators }\end{array}$ & No action required & $\begin{array}{l}\text { Require that } \\
\text { operators report } \\
\text { related occurrences }\end{array}$ & $\begin{array}{l}\text { Record and report } \\
\text { related occurrences }\end{array}$ \\
\hline Measure 8 & $\begin{array}{l}\text { One-way passengers } \\
\text { trips per hour }\end{array}$ & No action required & $\begin{array}{l}\text { Data already } \\
\text { available - monitor } \\
\text { on an ongoing basis }\end{array}$ & No action required \\
\hline Measure 9 & $\begin{array}{l}\text { Rural rider usage of } \\
\text { urban system services }\end{array}$ & No action required & $\begin{array}{l}\text { On an ongoing basis, } \\
\text { require that operators } \\
\text { report related } \\
\text { occurrences, if } \\
\text { known }\end{array}$ & $\begin{array}{l}\text { Record and report } \\
\text { related occurrences, } \\
\text { if known }\end{array}$ \\
\hline Measure 10 & $\begin{array}{l}\text { Availability of local } \\
\text { travel training service }\end{array}$ & $\begin{array}{l}\text { Identify industry } \\
\text { best practices and } \\
\text { report to NDDOT }\end{array}$ & $\begin{array}{l}\text { Consider policy } \\
\text { requiring that } \\
\text { operators provide } \\
\text { travel training } \\
\text { services to first-time } \\
\text { users }\end{array}$ & $\begin{array}{l}\text { Provide prescribed } \\
\text { travel training } \\
\text { services and report } \\
\text { provision to related } \\
\text { services to NDDOT }\end{array}$ \\
\hline
\end{tabular}


Regarding shared vehicles, the regions' managers, plus those in other regions, were asked about industry practices with regard to loaning vehicles from one service provider to another. This practice does occasionally occur, primarily when one operator has a service breakdown outside its home area and another nearby operator has a spare vehicle that it can make available, on a short term basis, to complete scheduled trips. This practice might also reduce operating costs if an operator in a destination city can make a vehicle available for a few hours during a day while routine maintenance or warranty work is being done. Having this type of access might eliminate the need to bring vehicles in without passengers to have related work done.

While this practice should be encouraged, it is also important that the loaning and borrowing entities be aware of related insurance implications. Because most North Dakota transit operators have vehicle insurance through the North Dakota Insurance Reserve Fund (NDIRF), SURTC researchers contacted NDIRF to determine whose insurance policy would provide coverage if an accident occurred while a vehicle was being operated by someone other than its owner.

According to NDIRF, it is a standard industry practice to have insurance coverage provided by the vehicle's owner, unless some other form of written agreement is in place. This being the case, a loaning agency may ultimately be responsible for damages if an accident occurred while a vehicle was being operated by a borrowing operator. The loaning agency could also be faced with higher insurance premium payments as a result of a related accident.

SURTC researchers felt that it was important for transit operators to be aware of potential liability issues. In consultation with NDDOT transit staff members, a corresponding set of advisory guidelines were prepared. Those guidelines, a copy of which is presented in Appendix F, were finalized and subsequently discussed at the semi-monthly status report meeting on June 4, 2012. It may be appropriate for NDDOT's transit staff to share these guidelines with all of the state's transit managers.

\subsubsection{Develop Short- and Long-term Budgets}

Short- and long-term budgets for regional coordination are obviously dependent on related recommendations concerning the number of coordination managers involved, job descriptions, etc. Those recommendations have been developed based on the provisions of Senate Bill No. 2223, input received from the regions' transit managers, discussions with mobility managers in the state's urban areas, and NDDOT Transit Section's prior actions and current visions regarding regional transit coordination. Those recommendations and corresponding short- and long-term budgets will be presented in the final chapter of this report.

\subsubsection{Work with Mobility Managers to Facilitate Coordination}

The transit systems in each of North Dakota's urban areas (Fargo, Bismarck, and Grand Forks) employ a mobility manager. These managers are funded primarily with federal monies administered by NDDOT"s Transit Section and were consulted throughout this coordination project to determine what role they might play in facilitating the overall coordination effort.

The mobility managers in Fargo and Bismarck work exclusively for their respective transit systems. They have broad areas of responsibility, but their primary function regarding mobility management is travel training, both for individual travelers and for entities or organizations that provide mobility assistance to current or potential travelers. For individual travelers, this training might include verbal instructions and the provision of written materials, or even making actual trips with individuals to familiarize them with system operations, routes, transfers, purchasing tickets, scheduling trips, etc. 
Travel training is also provided to advocacy groups such as human service agencies or any other entity interested in learning more about local transit services. This training better equips these entities and their employees to educate their clients regarding the availability and operations of local transit services.

The mobility managers from Bismarck and Fargo made related presentations to the regions' rural transit managers at the quarterly NDDOT transit meeting on January 25, 2012. SURTC researchers and NDDOT transit staff deemed it important that the rural operators be familiar with urban services so they could help their riders make use of related services when they were in the urban area, either during day trips or for an extended period of time.

The mobility manager in Grand Forks functions in a slightly different manner. In addition to performing typical mobility manager duties, that individual also meets with the northeast region's rural transit managers quarterly to discuss ways in which those systems can coordinate their services with one another and with the Grand Forks urban system. While the vast majority of that person's time is currently devoted to urban operations, plans call for up to $50 \%$ of the position's time to eventually be devoted to providing regional transit coordination services throughout the region. Related costs would be apportioned to each of the region's operators. Grand Forks would pay 50\% and the region's rural transit systems would pay the remaining 50\%. Federal funding would be available through NDDOT on an 80-20 basis. Assuming a $\$ 100,000$ annual budget, Grand Forks' local share would be $\$ 10,000$ ( $\$ 100,000 \times 50 \%$ x $20 \%$ ). The region's rural operators would have a similar, aggregate local share of $\$ 10,000$.

In July 2012, Grand Forks' Cities Area Transit was awarded a federal $\$ 1.77$ million Veterans Transportation and Community Living Initiative grant. The intent of the grant program was to make it easier for veterans and others to learn about and arrange for locally available transportation services and to thereby gain increased access to work, education, health care, and other services.

Cities Area Transit plans to use grant funds to provide rural transit operators in five northeastern counties with computer equipment that will provide operators and the public online access to information regarding operator schedules and to thereby facilitate operator coordination. The system can also be used to establish a one-call regional ride reservation system. This grant requires a $20 \%$ local match, which will be provided by participating project partners. The total local share of the $\$ 1.77$ million grant is $\$ 354,000$.

Approximately \$1.32 million of the grant's funds will be used to purchased computer hardware and software for transit operators in other areas of the state. This technology will provide the state's larger rural transit operators with ready access to schedule information from other transit systems. It will also facilitate future efforts regarding regional one-call reservation centers.

This project's scope of work references the fact that NDDOT's Transit Section envisioned that North Dakota Community Action would also be employing a regional transit coordinator to facilitate both coordination among transit service providers and the personal mobility needs of the state's transportationdependent residents. In mid-2012 NDDOT executed a related contract with Community Action and provided $80 \%$ federal funding for the position. The corresponding staff position was filled in August 2012. That person's activities will focus on the south central pilot region. In October 2012, NDDOT executed a similar contract with Bis-Man Transit to hire a regional transit coordinator to facilitate coordination and personal mobility in the west central pilot region. North Dakota Community Action and Bis-Man Transit are providing the required 20\% local match for their respective positions. 


\subsubsection{Hold Semi-monthly Progress Meetings with NDDOT's Transit Staff}

The 2010 coordination study had an extremely short delivery period. To keep the project on schedule, it was decided that SURTC and NDDOT's transit staff would meet twice a month to discuss ongoing activities. That process worked extremely well, and it was decided to continue it during the current project implementation phase.

Semi-monthly meetings were held starting in October 2011. These meetings were used to keep NDDOT's transit staff apprised of ongoing activities and gave SURTC researchers ready access to NDDOT staff members who provided related information and direction. Meetings were typically held in NDDOT's central office in Bismarck. SURTC's Bismarck staff attended meetings in person, while Fargo-based researchers typically participated by phone. As was the case with the prior study, these meetings were very beneficial and provided SURTC researchers and NDDOT transit personnel with an opportunity to exchange information and to ask and answer questions that helped keep work on various tasks on schedule.

\subsubsection{Document Coordination-related Achievements}

Achievements related to all 17 of this project's tasks are presented throughout this chapter. This particular subsection focuses on achievements specific to operator service modifications.

The 2010 coordination report identified a series of operator-specific opportunities for coordination. Additional opportunities were identified via the coordination self-assessment questionnaire discussed earlier in Subsection 3.2.2. The regions' transit managers were asked to complete that questionnaire in an e-mail dated December 6, 2011. As indicated earlier, a compilation of operator responses is presented in Appendix B.

Assignments for related discussions were presented to the regions' transit managers on April 26, 2012, at a quarterly NDDOT transit meeting. The operators involved in each operating scenario were asked to schedule a meeting to discuss possible service modifications. SURTC and NDDOT transit personnel were to be invited to attend. After each meeting, the operators were to submit a related report describing what, if any, actions would be taken to modify existing services.

The following paragraphs of this subsection identify assignments that were given to each group of operators regarding opportunities for enhanced coordination and resulting operator decisions regarding related service modifications.

\section{Dickey County Transportation and South Central Transit Network}

Assignment - Both service providers make regularly scheduled trips to Aberdeen, SD. Operators were asked to discuss the possibility of consolidating services to provide a single trip to Aberdeen. Dickey County could pick-up passengers within the county and rendezvous with South Central's McIntosh County bus in Ellendale. South Central's bus could then take all the passengers to Aberdeen and back. Dickey County's bus could be used that day to provide local service in Ellendale or elsewhere in the county while it waits for the return of South Central's bus. Related discussions should take place regarding feasibility, a timetable for implementation, and the standardization of fares.

Outcome - Program directors determined that the overall demand for service to Aberdeen is sufficient to warrant the service being provided by both providers. It was also, decided, however, that Dickey County would continue to publicize the availability of service from Ellendale to Aberdeen via South Central. Local residents would, therefore, be given a second travel option for trips to and from Aberdeen. 


\section{James River Transit and South Central Transit Network}

Assignment - Both operators provide regularly scheduled service to Fargo via I-94. The operators were asked to discuss the possible coordination/reconfiguration of their services and the standardization of fares.

Outcome - South Central travels from Valley City to Fargo Monday-Friday while James River goes from Jamestown to Fargo on Wednesdays. Both services are heavily utilized, and there is no opportunity to consolidate services and eliminate trips. However, on those days that James River does not go to Fargo, the operators agreed that James River would pick up passengers in Jamestown and bring them to Valley City, at which point they would transfer to South Central's bus for travel to Fargo and back. This arrangement does result in deadhead miles when James River's driver returns to Jamestown until it is time to go back to Valley City to pick-up returning passengers. Additional discussions are planned to identify ways to eliminate deadhead miles and related costs. The region's new transit coordinator may facilitate related discussions.

As illustrated earlier in the fare comparison chart in Table 2.9, there is a significant difference in the fares for Fargo-bound service provided by James River vs. South Central (\$.175/mile vs. \$.037/mile). Each operator's fares are set by their governing board, and board action is required to make related changes. Corresponding actions should be pursued to reduce existing fare differentials.

\section{James River Transit, Kidder County Transit, South Central Transit Network, and West River Transit}

Assignment - Each operator makes regularly scheduled westbound trips to Bismarck via I-94. They were asked to discuss the possible coordination/reconfiguration of these trips and the standardization of fares.

Outcome - It was decided that Kidder County's bus that travels from northern Kidder County to Bismarck via Steele will revise its route to come to Bismarck through northern Burleigh County, thereby increasing service to the West River Transit communities of Wing and Regan. To provide Steele residents with access to Bismarck, James River will begin serving that community as it travels from Jamestown to Bismarck. Project directors will work together to publicize and promote related changes and travel options. Further discussions are planned regarding the coordination of South Central Transit's services along the I-94 corridor to Bismarck. The region's new transit coordinator may facilitate related discussions.

James River's fares currently equate to $\$ .175$ per mile while Kidder County’s fares are equal to $\$ .089$ per mile. Additional discussions need to take place to reduce this differential and to thereby eliminate a disincentive that may discourage the use of James River's services by residents of Steele. Related board of directors action may be required by both service providers.

\section{Benson County Transit, James River Transit/Wells-Sheridan Public Transit, Kidder County Transit, and West River Transit}

Assignment - All four of these operators provide westbound service to Bismarck via I-94. The inbound routes followed by Benson County, Wells/Sheridan, and Kidder County also travel south along North Dakota Highway 3. The operators were asked to discuss possible coordination/reconfiguration and the standardization of fares. 
Outcome - It was agreed that Benson County Transit would begin providing regular service to Harvey, Tuttle, and Steele along its route from Benson County to Bismarck. Benson County will charge all passengers the fares that are charged by their current service provider. Adding these pick-up points will allow Wells/Sheridan and Kidder County to discontinue related trips to Bismarck, thereby freeing-up resources to provide other mobility options to area residents.

One such option may involve the initiation of a route by Wells/Sheridan from Harvey to Devils Lake. This new route might eliminate the need for an existing route currently being run by Benson County to Devils Lake. Wells/Sheridan Public Transit will conduct a local needs assessment to determine if there is enough local demand for this service, or if some other service offering would be more valuable to area residents. The region's new transit coordinator may facilitate related discussions.

\section{Glen Ullin Public Transportation and West River Transit}

Assignment - Both operators provide weekly eastbound service to Bismarck via I-94; West River's vehicles originate in Hebron and pass by Glen Ullin on the way to Bismarck. Both operators also provide monthly westbound service to Dickinson with Glen Ullin passing by Hebron as a part of its route. The operators were asked to discuss the possible coordination/reconfiguration of these services and the standardization of fares.

Outcome - The program directors agreed to begin serving the each other's community - Glen Ullin will serve Hebron on its way to Dickinson, and West River will serve Glen Ullin on its way to Bismarck. The net effect will be a doubling of service options to the residents of both communities. Both the Glen Ullin and the Hebron buses will also begin offering their Bismarck-bound services to residents of New Salem, thereby doubling that community's travel options to Bismarck. Both operators will promote the expanded service options in their respective communities. The region's new transit coordinator may facilitate and monitor related efforts.

Glen Ullin currently subsidizes the fares paid by local residents. Its advisory board agreed to pay a comparable subsidy to West River when the Hebron-based bus transports Glen Ullin residents to Bismarck.

\section{Hazen Busing and West River Transit}

Assignment - Both operators provide weekly service from the Beulah/Hazen area to Bismarck and monthly service to Dickinson. They were asked to discuss the possible coordination/reconfiguration of these services and the standardization of fares. They were also asked to discuss the possible expansion of local services in Beulah by Hazen Busing.

Outcome - The operators agreed that the demand for service to Bismarck is sufficient to warrant weekly service by both systems. The operators agreed to publicize each other's schedules so local residents would be aware of both service options. Fares are not an issue since they are very comparable.

The operators also agreed that it may be possible to satisfy the demand for service to Dickinson with one bus making the trip once a month. Hazen Busing plans to discuss the matter with its advisory board; and, with the board's consent, it would discontinue its service to Dickinson and work with West River Transit to promote West River's Dickinson service to local residents.

Concerning local transit services in Beulah, SURTC and NDDOT staff members met with Hazen and Beulah officials on March 30, 2012, to discuss the possible extension of various Hazen Busing services to residents of Beulah. At the conclusion of the meeting, Beulah officials were asked report back with a list 
of services that it desired, and Hazen Busing would then prepare a related budget for Beulah's consideration.

On August 29, 2012, Hazen's city auditor/transit manager announced her resignation effective September 7, 2012. Her departure left several of the previously discussed service modifications unsettled. It is expected that future actions will be dependent on the hiring of a permanent replacement. The region's new transit coordinator may facilitate subsequent actions.

\subsection{Phase V - Prepare and Present Coordination Implementation Report}

The fifth and final phase of this project involved two tasks - the preparation of a coordination implementation report and the presentation of that report to NDDOT. Activities related to these tasks are discussed in the following subsections.

\subsubsection{Prepare Coordination Implementation Report}

This project's scope of work calls for the preparation of a report detailing coordination efforts undertaken to implement Senate Bill No. 2223, as enacted by the 2009 Legislature. Specifically, the report was to include:

- Information concerning local and regional coordination efforts,

- Efforts to publicize the availability of local transit services,

- Reduced fragmentation and duplication,

- Efficiencies gained as a result of increased duplication,

- Changes in personal mobility, and

- Proposed regional coordination administrator budgets, including anticipated cost versus benefits.

As with the 2010 coordination, SURTC researchers provided NDDOT's transit staff with draft copies of individual chapters of the report as they were completed, thereby allowing for sequential and ongoing review and feedback vs. the review of the entire report only after it was completed. Related revisions were subsequently made, based on input received from NDDOT's transit staff. The resulting chapters were then sent to the regions' transit managers for their review and comment. The draft report was also sent to transit managers outside the two pilot regions. The end result of this process was the submission of a final report that had been reviewed by both NDDOT transit personnel and all of North Dakota's transit operators.

\subsubsection{Present Implementation Report to NDDOT}

The project's scope of work specified that the project's draft report was to be presented to NDDOT by mid-November 2012. SURTC researchers met with NDDOT's transit staff on November 19, 2012, to rereview all the report's draft chapters, as well as any input that was received from any of North Dakota's transit managers. The report was presented to NDDOT's Executive Management Team on November 26, 2012. The finalized printed report was delivered to NDDOT in December 2012. 


\section{RECOMMENDATIONS FOR FURTHER COORDINATION AND CORRESPONDING BUDGETS}

This final chapter presents recommendations and related budgets pertaining to future transit coordination efforts in North Dakota. These recommendations are based on the provisions of Senate Bill No. 2223 as enacted by the 2009 Legislature, a copy of which was presented earlier in Figure 1.1. These recommendations also seek to facilitate North Dakota's ongoing efforts to comply with federal transit coordination mandates.

This chapter is divided into three sections. The first section presents recommendations that are specific to the two pilot regions that have been the focus of this implementation project. The second section addresses actions that may be prudent regarding the expansion of current coordination efforts to provide statewide coverage. The final section discusses other related efforts that would facilitate transit coordination, operator efficiencies and effectiveness, and personal mobility in North Dakota.

\subsection{Continue Coordination in Pilot Regions}

Chapter 3 discussed achievements related to each of this project's 17 tasks. All of the regions' rural transit managers agreed that there were positive benefits associated with the current coordination project, especially related to the creation or updating of local websites, creating or otherwise identifying industry best practices policies, and quarterly meetings that helped educate operators regarding each other's services. Some operators were, however, concerned that continuing coordination efforts might impose additional costs on local operators and reduce the amount of federal assistance that they currently receive to support their operations. As indicated earlier, their specific comments are presented in Appendix D.

It is assumed that the 2009 Legislature hoped that coordination efforts in the two pilot regions would be beneficial and that related efforts would not only continue, but also be expanded to other regions of the state. There are also federal mandates regarding the coordination of local transit services.

Given these facts, it is recommended that the coordination efforts initiated by this project be continued in the two pilot regions. The following subsections discuss related issues regarding coordinator locations, job functions, budgets, and funding options.

\subsubsection{Regional Transit Coordinator Positions and Locations - Pilot Regions}

Senate Bill No. 2223 states that, "Each pilot region must have a regional coordination administrator. .." NDDOT complied with this mandate via the contracts that were discussed previously in Section 3.3.4. Those contracts with North Dakota Community Action and Bis-Man Transit facilitated the hiring of regional transit coordinators for the south central and west central pilot regions.

Contracting with these entities eliminated the need for NDDOT's Transit Section to hire its own full-time employees and gives the department the flexibility to modify corresponding contracts as situations warrant. Related occurrences might include altering the geographic size of existing regions, modifying job descriptions, voiding contracts due to unsatisfactory performance by the contracting entity or newly hired staff, or the loss of program funding. Eventually, it is envisioned that these individuals may be able to coordinate transit operations in not only their respective regions, but also in other areas of the state.

The eventual size of each coordination region will also impact the performance of each regional transit coordinator. It appears that Senate Bill No. 2223 deliberations were based on the state's traditional eight 
planning regions. It is recommended that, during the implementation phase, NDDOT's Transit Section continue to use the geographic regions identified by the department pursuant to Senate Bill No. 2223.

Those regions vary slightly from the traditional planning regions, but only to the extent that they adhered to the service areas of the regions' existing transit operators. These regions, which include 12 counties in the south central region and 7 counties in the west central region, were identified earlier in Figure 1.2. These regions were outlined for the Legislature when NDDOT presented the 2010 coordination report to the Legislative Council in January 2011.

Note that both the 2010 coordination report, and the November 2010 North Dakota Public Transit Needs Assessment report prepared for NDDOT by Ulteig Engineering, suggested that it may be appropriate to divide the state, for transit purposes, into something other than the traditional eight planning regions. Related discussions will be presented in Section 4.2.

Regarding the specific locations of regional transit coordinator offices, the exact base of operations for regional transit coordinators is highly dependent on the entity that NDDOT contracts with to provide related services because that entity will, in all likelihood, also be providing office space at its local office.

The current situation regarding the hiring of two regional coordinators resulted in one coordinator being collocated with a transit operator (Bis-Man Transit in Bismarck), while the other resulted in the coordinator being based apart from a transit service provider (North Dakota Community Action in Fargo). When collocation with a transit operator does not occur, special efforts must be taken to provide ongoing opportunities for mentoring from NDDOT's transit personnel, the state's other regional transit coordinators, and other experienced transit personnel.

\subsubsection{Regional Transit Coordinator Qualifications and Job Functions - Pilot Regions}

Transit coordinator positions are common across the country. There is not, however, a uniform set of position qualifications and job duties for such positions. Rather, related qualifications and job duties are dictated by local needs.

To identify qualifications and job duties appropriate for the recommended regional transit coordinator positions, SURTC researchers looked first to Senate Bill No. 2223, and then to a wide array of other sources. These other sources included: job descriptions for North Dakota's urban area mobility managers; tasks outlined in this project's scope of work; the job description presented in North Dakota Community Action's July 16, 2012, job announcement for a transportation coordinator; input received from the regions' rural transit managers; and job descriptions for similar positions elsewhere around the country. Recommended qualifications and job duties are presented in Figure 4.1.

As Figure 4.1 indicates, an ideal candidate for a regional transit coordinator position should have a bachelor's degree in transportation, social services, business, or a related field and transit-related management and work experience. Successful candidates should be personable and possess excellent verbal and written communication skills, along with organizational skills and the ability to handle multiple projects simultaneously. Candidates should also be self-directed and highly motivated, with computer, analytical, and budgeting skills.

In addition to these qualifications, Figure 4.1 also identifies 16 job duties and responsibilities. Most of the listed duties and responsibilities are synonymous with typical transit coordinator positions. Note that items 2-5 relate to specific provisions of Senate Bill No. 2223, while items 6-11 pertain to various duties that were discussed previously in Chapter 3. 


\section{Qualifications:}

1. Bachelor's degree in transportation, social services, business, or related field; may substitute a combination of education, training, and experience that demonstrate competency

2. Transit-related management and work experience with public bodies are highly desired

3. Personable with excellent verbal and written communication skills

4. Organizational skills, detail oriented, and able to coordinate multiple projects simultaneously

5. Self-directed, highly motivated, and creative with computer, analytical, and budgeting skills

6. Possess a valid driver's license and access to an insured vehicle for work-related travel

\section{Job duties and responsibilities:}

1. Be familiar with the services, fares, and general operations of all the region's public transit agencies

2. Work with public transit operators, human service agencies, and other entities to coordinate transit services within the region and with transit operators in other regions

3. Promote positive working relationships with and among transit service providers, social service agencies, and business and community leaders that result in enhanced personal mobility and/or increased operating efficiency and effectiveness

4. Assist communities with public transportation planning to develop a structure that will support a coordinated public transportation system

5. Assist NDDOT with the development of standards for public transportation providers and contractors who provide public transportation services

6. Work with rural transit providers to establish local transit advisory committees, where they do not exist, and work with committees and transit managers to identify unmet personal mobility needs and to develop services that are responsive to the needs of the public, especially those of individuals with disabilities, older adults, and low-income individuals

7. Schedule and prepare agendas for quarterly meetings of the region's transit managers

8. Monitor local transit websites and encourage operators to keep sites current

9. In conjunction with NDDOT's Transit Section, monitor operators' operating statistics and meet with managers and their local advisory board to discuss related performance measures, to develop appropriate operating goals and courses of action, and to achieve prescribed farebox recovery ratios

10. Work with rural transit operators to develop promotional materials, marketing campaigns, and travel training programs to encourage the use of transit services

11. Work with NDDOT's Transit Section and North Dakota's other regional transit coordinators to develop long-term, enhanced transit coordination and personal mobility plans, including the possible implementation of one-call reservation centers, and to monitor operator service reliability and the impacts of coordination

12. Assist with the development of local volunteer driver programs to augment the provision of local transit services

13. Assist local operators who are trying to identify options for individuals who are attempting to make atypical travel arrangements to, from, or within the region

14. Coordinate activities with NDDOT's Transit Section and North Dakota's other regional transit coordinators

15. Attend conferences, meetings, and trainings that are appropriate to the position

16. Report ongoing activities to NDDOT's Transit Section via required written reports

Figure 4.1 Regional Transit Coordinator Qualifications and Job Duties - Pilot Regions 
Newly-hired regional transit coordinators may not have a complete skill set that is necessary to fulfill all the duties outlined in Figure 4.1. Some of these skill sets will be developed via subsequent job exposures, mentoring, etc. Related training, both initial and ongoing, will also be required to build and enhance proficiencies. Desirable educational offerings might include:

- Community Transportation Association of America annual conference

- American Public Transit Association annual mobility management conference

- Dakota Transit Association annual conference

- Instruction specific to travel training

- Principles of Transit Management course offered by SURTC, both locally and nationally

- NDDOT-sponsored transit training on topics such as cost allocation

As is the case with training available to North Dakota's rural transit operators, it is anticipated that costs associated with much of this training may be covered with federal Rural Technical Assistance Program (RTAP) funds administered by NDDOT's Transit Section.

\subsubsection{Budgets and Funding Sources - Pilot Regions}

The 2010 coordination report recommended that NDDOT's Transit Section fill regional transit coordinator positions based in the south central and west central pilot regions with either full-time employees or via contracts with other entities. As discussed earlier, the department subsequently contracted with North Dakota Community Action and Bis-Man Transit to fill the coordinator positions mandated by Senate Bill No. 2223. These contracts may be terminated or subject to non-renewal if the partnerships prove to be undesirable to either party or if future needs warrant other changes.

It is envisioned that future contracts for regional transit coordinator services might include funding for not only staffing, but also for things such as employee travel, office space, office equipment and supplies, and administrative oversight. SURTC researchers compiled related cost estimates based on transit coordinator expenses incurred by Grand Forks' Cities Area Transit, Fargo's Metro Area Transit, and NDDOT's current contracts with North Dakota Community Action and Bis-Man Transit for related services.

Twelve-month cost estimates are presented in Table 4.1, along with year two and year three estimates based on an annual inflation rate of 3\%. Second-year expenses related to office equipment and supplies were reduced based on anticipated year one expenditures for computer-related equipment that would not reoccur in year two. Based on NDDOT's newly-executed regional transit coordinator contracts with North Dakota Community Action and Bis-Man Transit, the cost estimates presented in Table 4.1 do not include reimbursement for office rent or administrative oversight. If future contracts include related costs, this line item may increase by $\$ 9,000$ or more per contract per year.

The travel and training costs projected for each contract in Table 4.1 are based on 20,000 miles of annual travel in a personal vehicle at a federal rate of $\$ .55$ per mile. In addition to this $\$ 11,000$ expense, this line item also includes $\$ 4,000$ for lodging and meals.

As indicated earlier, some of the positions' travel and training costs may be eligible for RTAP funding. If that is not the case, Table 4.1's travel and training line item could increase by approximately $\$ 5,000$ per contract per year. 
Table 4.1 Regional Transit Coordination Budgets - Pilot Regions

\begin{tabular}{|c|c|c|c|}
\hline Expense Item & $\begin{array}{c}\text { Year One } \\
2013\end{array}$ & $\begin{array}{c}\text { Year Two } \\
2014\end{array}$ & $\begin{array}{c}\text { Year Three } \\
2015\end{array}$ \\
\hline Salary and benefits & $\$ 70,000$ & $\$ 72,100$ & $\$ 74,300$ \\
\hline Travel and training & $\$ 15,000$ & $\$ 15,500$ & $\$ 16,000$ \\
\hline Office equipment, printing, and supplies & $\underline{\$ 10,000}$ & $\$ \quad 5,200$ & $\$ \quad 5,300$ \\
\hline Total per position & $\$ 95,000$ & $\$ 92,800$ & $\$ 95,600$ \\
\hline Less $20 \%$ local share & $\underline{\$ 19,000}$ & $\$ 18,560$ & $\$ 19,120$ \\
\hline Federal funds required for each positions & $\$ 76,000$ & $\$ 74,240$ & $\$ 76,480$ \\
\hline Number of positions & $\mathrm{x} 2$ & $\mathrm{x} 2$ & $\mathrm{x} 2$ \\
\hline Total federal funds required for 2 positions & $\$ 152,000$ & $\$ 148,480$ & $\$ 152,960$ \\
\hline
\end{tabular}

As indicated earlier, the cost estimates presented in Table 4.1 are based on coordinator expenses incurred by Grand Forks' Cities Area Transit, Fargo's Metro Area Transit, and NDDOT's current contracts with North Dakota Community Action and Bis-Man Transit. The actual federal share of NDDOT's current contracts with North Dakota Community Action and Bis-Man Transit is approximately $\$ 66,700$ per contract. If this amount proves to be the actual long-term federal share, the total federal share for the two positions would be approximately $\$ 133,400$ per year, plus inflation.

NDDOT's Transit Section is financing the current contracts with North Dakota Community Action and Bis-Man Transit using FTA Section 5316 Job Access Reverse Commute (JARC) and Section 5317 New Freedom funds. These funds were allocated to states on a formula basis under the 2005 Safe, Accountable, Flexible, Efficient Transportation Equity Act - Legacy for Users (SAFETEA-LU) federal highway bill. Corresponding funds came to North Dakota each fiscal year from 2007 through 2012; NDDOT's Transit Section has up to three years to obligate each year's funds. Related federal appropriations are summarized in Table 4.2.

As Table 4.2 illustrates, under SAFETEA-LU, the 5316 and 5317 programs each had a rural and an urban component. Funding rural transit coordinator positions with rural program funds is an allowable expense, while urban program funds may only be used if there is an urban component to the related position. As a result, the south central coordinator position cannot be funded with SAFETEA-LU urban monies because there is not an urban area in that region. Conversely, the west central position does have an urban component because the region includes the Bismarck urban area.

NDDOT's Transit Section is using 2010, 2011, and 2012 program funds to finance the newly-created regional transit coordinator positions in the two pilot regions. These obligations are included in the obligation amounts presented in Table 4.2. With these obligations, North Dakota's 2010 allocations are fully committed and only a small portion of its 2011 funding remains.

As Table 4.2 indicates, only about 5\% of North Dakota's 2012 allocations for the 5316 and 5317 programs have been obligated. It appears, therefore, that funding is sufficient to fund the pilot regions' new regional transit coordinator positions for at least the program's second year, which will run through late 2014. Subsequent 2014 contracts could also draw on 2012 program funds, if they are still unobligated. This approach will help NDDOT fully utilize its SAFETEA-LU transit allocations. 
Table 4.2 Federal Transit Funding - North Dakota Appropriations (2010-2012)

FY 2010 FTA SAFETEA-LU Funding

\begin{tabular}{|l|c|c|c|}
\hline & Appropriated & Obligated & Available \\
\hline 5316 - JARC Rural & $\$ 168,645$ & $\$ 168,645$ & $\$ 0$ \\
\hline 5316 - JARC Urban & $\$ 221,881$ & $\$ 221,881$ & $\$ 0$ \\
\hline 5317 - New Freedom Rural & $\$ 78,396$ & $\$ 78,396$ & $\$ 0$ \\
\hline 5317 - New Freedom Urban & $\$ 126,173$ & $\$ 126,173$ & $\$ 0$ \\
\hline Total & $\$ 595,095$ & $\$ 595,095$ & $\$ 0$ \\
\hline
\end{tabular}

FY 2011 FTA SAFETEA-LU Funding

\begin{tabular}{|l|c|c|c|}
\hline & Appropriated & Obligated & Available \\
\hline 5316 - JARC Rural & $\$ 161,002$ & $\$ 153,396$ & $\$ 7,606$ \\
\hline 5316 - JARC Urban & $\$ 211,825$ & $\$ 152,939$ & $\$ 58,886$ \\
\hline 5317 - New Freedom Rural & $\$ 76,941$ & $\$ 76,263$ & $\$ 0$ \\
\hline 5317 - New Freedom Urban & $\$ 123,831$ & $\$ 108,989$ & $\$ 14,842$ \\
\hline Total & $\$ 573,599$ & $\$ 491,587$ & $\$ 81,334$ \\
\hline
\end{tabular}

FY 2012 FTA SAFETEA-LU Funding

\begin{tabular}{|l|c|c|c|}
\hline & Appropriated & Obligated & Available \\
\hline 5316 - JARC Rural & $\$ 162,540$ & $\$ 0$ & $\$ 162,540$ \\
\hline 5316 - JARC Urban & $\$ 213,849$ & $\$ 0$ & $\$ 213,849$ \\
\hline 5317 - New Freedom Rural & $\$ 77,338$ & $\$ 28,348$ & $\$ 48,990$ \\
\hline 5317 - New Freedom Urban & $\$ 124,741$ & $\$ 0$ & $\$ 124,741$ \\
\hline Total & $\$ 578,468$ & $\$ 0$ & $\$ 550,120$ \\
\hline
\end{tabular}

In mid-2012, Congress enacted new federal highway and transit funding legislation - Moving Ahead for Progress in the $21^{\text {st }}$ Century (MAP-21). That legislation rolled the New Freedom program into the Section 5310 program, which provides funding for transporting elderly persons and individuals with disabilities. The JARC program was rolled into the Section 5311 program, which provides funding for transit in non-urban areas, and into the 5307 program, which provides funding for transit operations in urban areas. 5311 funds are distributed to states on a formula basis and are then administered by each state's department of transportation. 5307 funds flow directly from the FTA to urban areas.

According to NDDOT's transit staff, North Dakota's appropriation for the 5311 rural transit program increased from \$4,011,786 for FY 2012 under SAFETEA-LU to \$4,962,111 for FY 2013 under MAP-21. While this looks like a sizable increase, it is important to note that MAP-21 rolls previous JARC monies into the 5311 program and New Freedom monies into the 5310 Program. Adjusting for these consolidations, the actual increase in funding equals approximately $\$ 574,000$, a net increase of $13 \%$.

MAP-21 provides states with funding for FY 2013 and 2014. States will have through FY 2016 to expend their FY 2013 appropriations and through FY 2017 to spend FY 2014 federal funds.

On October 16, 2012, the FTA published a notice regarding the implementation of MAP-21. These guidelines confirm that there are no specific appropriations for the JARC and New Freedom programs. States do, however, have the ability to fund related projects using appropriated Section 5310 and 5311 funds. The amount of 5311 funds that states may use for administrative purposes, including coordination activities, was reduced from $15 \%$ to $10 \%$. 
Table 4.3 projects how much money might be available under MAP-21 for JARC and New Freedom activities, including coordination, assuming a comparable level of apportionment by NDDOT's Transit Section. As Table 4.3 indicates, FY 2013 funding may approach $\$ 580,000$. Related expenditures could be made through FY 2016.

Table 4.3 MAP-21 - North Dakota FY 2013 Appropriations

\begin{tabular}{|l|c|c|c|}
\hline & Appropriated & Obligated & Available \\
\hline $5316-$ JARC & $\$ 0$ & $\$ 0$ & $\$ 0$ \\
\hline 5317 - New Freedom & $\$ 0$ & $\$ 0$ & $\$ 0$ \\
\hline $\begin{array}{l}5310-\text { Seniors and Individuals with } \\
\text { Disabilities (discretionary spending } \\
\text { assumed to be comparable to prior } \\
5317 \text { appropriations) }\end{array}$ & $\$ 202,079$ & $\$ 0$ & $\$ 202,079$ \\
\hline $\begin{array}{l}5311-\text { Rural Transit (discretionary } \\
\text { spending assumed to be comparable to } \\
\text { prior 5316 appropriations) }\end{array}$ & $\$ 376,389$ & $\$ 0$ & $\$ 376,389$ \\
\hline Total & $\$ 578,468$ & $\$ 0$ & $\$ 578,468$ \\
\hline
\end{tabular}

As indicated earlier in Table 4.1 and related narrative, it is projected that the total federal share of the two regional coordinator positions ranges from $\$ 133,400$ to $\$ 152,000$ per year, plus inflation. It appears, therefore, that MAP-21 provides more than enough FY 2013 funding to cover expenses associated with the pilot regions' transit coordinator positions. Additional MAP-21 money will be available in FY 2014. States will have through FY 2017 to spend those funds.

Regarding the $20 \%$ local share identified earlier in Table 4.1, that amount is initially being provided by North Dakota Community Action and Bis-Man Transit. If these sources of local funding are not available long-term, the transit operators in each region may be called on to provide the required local match.

There are four rural operators in each pilot region, but it would be inequitable to assess each operator equally, because some are single-city or single-county systems while others serve multi-county areas. In either case, assessing local operators to provide the required local match would create an additional expense that they would have to finance with local funds. Based on the budget presented in Table 4.1, such an assessment would average just under $\$ 5,000$ per year.

Another funding option for the regional coordinator positions is the FTA Section 5311 program, which provides operating funds for the state's rural transit operators. While the 5316 and 5317 programs require a $20 \%$ local match, the 5311 program allows states to use up to $15 \%$ of the program's funds for administrative and planning purposes, with no match required. Transit coordination is an eligible program expense.

Fifteen percent of North Dakota's FY 2012 Section 5311 allocation equals nearly $\$ 602,000$, an amount that is more than sufficient to covers costs associated with the regional transit coordinator positions. Funding these positions with 5311 administrative funds would, however, reduce the amount of money currently provided to the state's rural transit operators, because NDDOT's Transit Section has historically not used any 5311 funds for administrative purposes. Rather, all program funds have been used to make corresponding operating grants to the state's rural transit operators. 


\subsection{Expand Coordination Efforts Statewide}

As discussed earlier, it is reasonable to assume that legislators hoped that transit coordination would prove successful in the two pilot regions mandated by Senate Bill No. 2223 and that related efforts would subsequently be pursued elsewhere in the state. As outlined in Chapter 3, coordination has produced positive results in the two pilot regions, and it is federally mandated. It also appears that federal funding may be available to support related efforts in the pilot regions and beyond.

Given these facts, it is recommended that NDDOT's Transit Section pursue a strategy that will ultimately result in statewide regional coordination. This section discusses related topics, including the number of coordination regions and regional transit coordinators in the state, coordinator job functions, and corresponding budgets and funding sources.

\subsubsection{Number of Coordination Regions and Coordinators - Statewide Coverage}

North Dakota is traditionally divided into eight regions for state highway planning and maintenance purposes. It appears that legislators based the provisions of Senate Bill No. 2223 on the assumption that transit coordination would precede along similar lines. With some minor adjustments to reflect operator service areas, NDDOT's Transit Section did, in fact, select the project's two pilot regions based on existing regional boundaries. Those minor adjustments were described in NDDOT's January 2011 report to the Legislature. Actions by NDDOT's Transit Section to facilitate the hiring of two regional transit coordinators, as discussed in the preceding section, also adhered to these geographic regions.

Earlier discussions in this report pointed out that both SURTC's 2010 coordination report and Ulteig Engineering's 2010 transit needs assessment report suggested that North Dakota may eventually be better served with fewer than eight coordination regions. A major consideration is the fact that the number of rural transit service providers in North Dakota has been gradually declining. Many single-city and singlecounty operators have consolidated with multi-county operators, some of which serve as many as seven counties. It is anticipated that this consolidation will continue. If so, related coordination regions may become larger and there will be fewer of them in the state.

The number and size of coordination regions will also be dependent on the job functions and abilities of the state's regional transit coordinators. These functions and abilities were discussed earlier in Section 4.1 and will be discussed further in the following pages as they relate to statewide coordination efforts.

As discussed in Section 4.1, NDDOT's Transit Section facilitated the hiring of a regional transit coordinator in both the south central and west central pilot regions. These regions are identified as regions B-1 and C-1 in Figure 4.2. This action was consistent with the provisions of Senate Bill No. 2223.

Ultimately, it is expected that each of the new coordinators may be able to assume additional duties associated with an expanded geographic area. It is not unreasonable to assume that experienced coordinators may be capable of fulfilling related duties in areas larger than the existing pilot regions, each of which has only four rural transit operators.

Expanded areas of responsibility could come in the form of either a second region or the expansion of the existing region. For administrative efficiency, the expansion of existing regions seems most appropriate. The opposite approach would, for example, necessitate quarterly operator meetings in each region. Conversely, expanding an existing region would eliminate the need for additional meetings and 
familiarize more rural operators with each other's operations. This knowledge and understanding would further increase opportunities for coordination.

The existing pilot regions each encompass roughly one-eighth of the state. Doubling the size of each region would increase their geographic size to approximately one-fourth of the state. Expanding this concept to cover the entire state would, therefore, result in the creation of four coordination regions and would require four regional transit coordinators.

Establishing related regional boundaries should consider factors such as the geographic size of resulting regions, the number of transit operators in each region, the region's population, and whether or not the region has an urban area. The number and exact boundaries of eventual regions will, however, be a work in progress, depending on the evolutionary number of rural service providers, coordinator job functions, and the capabilities of individual coordinators. It may also be necessary to have one or more additional coordinators devoted to the state's largest urban areas.

Figure 4.2 identifies potential regional transit coordination boundaries. This figure reflects the fact that the size of the existing pilot regions, B-1 and C-1, may eventually be expanded to include B-2 and C-2, respectively.

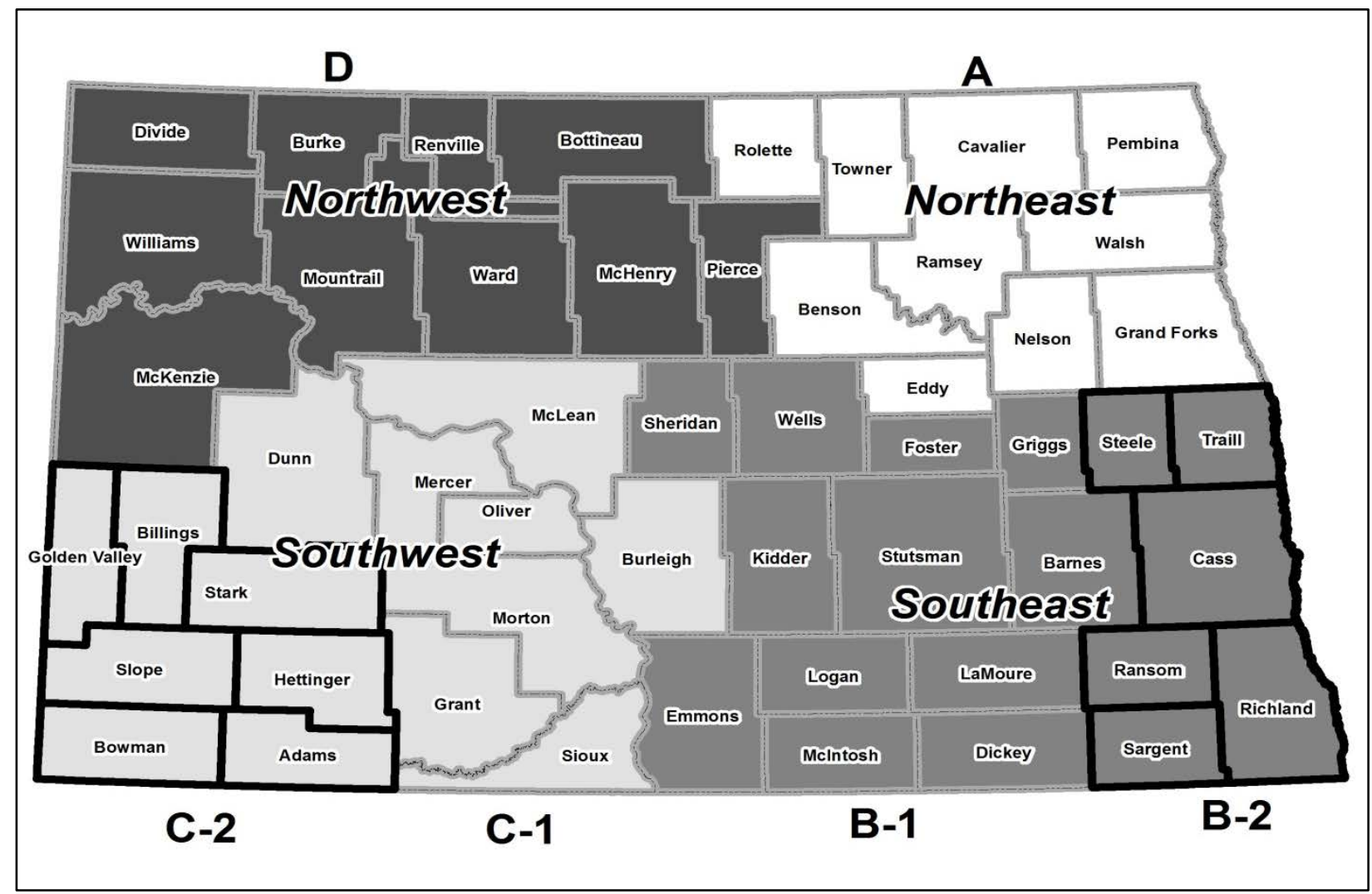

Figure 4.2 Potential Transit Coordination Regions - Statewide Coverage

As the map in Figure 4.2 illustrates, it is envisioned that North Dakota may eventually function with four transit coordination regions. Table 4.4 identifies the number of counties and transit operators in each region and each region's urban center, if any. The transit systems in each of the urban centers identified in Table 4.4, as well as Minot's transit system, provide both fixed-route and paratransit services. 
Table 4.4 Transit Regions - Counties, Rural Transit Operators, and Urban Centers

\begin{tabular}{|l|c|c|c|c|c|}
\hline \multicolumn{1}{c|}{ Region } & Counties & $\begin{array}{c}\text { Rural + Urban } \\
\text { Total Transit } \\
\text { Operators }\end{array}$ & Urban Center & $\begin{array}{c}\text { Total } \\
\text { Population* }\end{array}$ & $\begin{array}{c}\text { Rural } \\
\text { Population* }\end{array}$ \\
\hline A - Northeast & 10 & $13+1=14$ & Grand Forks & 128,993 & 76,362 \\
\hline B - Southeast & 18 & $7+1=8$ & $\begin{array}{c}\text { Fargo- } \\
\text { West Fargo }\end{array}$ & 251,424 & 117,784 \\
\hline C - Southwest & 15 & $7+1=8$ & $\begin{array}{c}\text { Bismarck- } \\
\text { Mandan }\end{array}$ & 176,982 & 95,810 \\
\hline D - Northwest & 10 & $6+0=6$ & None & 126,533 & 126,533 \\
\hline
\end{tabular}

*Source: U.S. Census Bureau 2011 Population Estimates

As Table 4.4 indicates, two of the envisioned regions encompass 10 counties, while the other two involve 15 and 18 counties, respectively. As discussed earlier, however, geographic size is only one consideration regarding the eventual formation of transit coordination districts. Another major consideration is the number of transit operators in each region.

As shown in Table 4.4, the number of operators in each of the proposed regions ranges from 6 to 14 . The number of operators in the northeast region is reflective of the fact that, unlike the other three regions, there is not a large, multi-county operator in that region. Despite this difference, the number of operators in each region is considered manageable for a single regional transit coordinator, depending on related job duties and coordinator capabilities.

The rural populations of the four regions range from just over 76,000 to approximately 126,500 . Including urban populations makes the southeast region significantly larger than the other three regions. This variance, plus federal funding issues that will be discussed later, may justify having a separate coordinator to manage the Fargo urban area.

As previously discussed, the transit system in each of North Dakota's three urban areas has a transit coordinator. These managers have all been funded, in part, with federal funds administered by NDDOT's Transit Section. Cities Area Transit in Grand Forks has indicated that its coordinator will work jointly with the region's rural transit operators, thereby satisfying the need for a regional transit coordinator to serve the northeast region of the state.

NDDOT's Transit Section initiated similar discussions with Bismarck's Bis-Man Transit. Via these discussions, it was determined that Bis-Man Transit would reassign its existing coordinator to other duties and hire a new regional transit coordinator to serve the urban area and the adjacent west central pilot region.

Given the population of the Fargo-West Fargo-Moorhead metropolitan area, it is questionable if that system's transit coordinator could assume related duties to encompass both the urban area and the entire southeast portion of the state. In addition, the Fargo position is jointly funded by NDDOT and the Minnesota Department of Transportation (MnDOT), with North Dakota covering approximately twothirds of related costs. If the Fargo position eventually assumes more duties associated with all of south east North Dakota, MnDOT's financial commitment to the position might diminish or be terminated.

It should also be noted that urban transit funding will change under MAP-21. Under SAFETEA-LU, states administer JARC and New Freedom funding, some of which has gone from NDDOT to Fargo to fund its local coordinator. Under MAP-21, urban areas, like Fargo, will finance JARC-like programs with Section 5307 monies received directly from the FTA. NDDOT will, therefore, have little or no 
direct involvement with related activities in the Fargo urban area. This change in funding sources will actually free-up a portion of North Dakota's related MAP-21 allocations for other purposes.

Based on the assumption that the two recently-hired regional transit coordinators will eventually be able to facilitate coordination activities in an expanded area, North Dakota will ultimately need up to five coordinators - one for each quadrant of the state and one for the Fargo urban area. As indicated in Table 4.5 , four of these coordinators are already in place.

Table 4.5 Existing and Proposed Regional Transit Coordinators - Statewide Coverage

\begin{tabular}{|c|c|c|c|}
\hline Current Service Area & Proposed Service Area & $\begin{array}{l}\text { Currently in Place - } \\
\text { Current Federal } \\
\text { Funding Source }\end{array}$ & $\begin{array}{l}\text { Projected MAP-21 } \\
\text { Funding Source }\end{array}$ \\
\hline Fargo Urban Area & No Change & $\begin{array}{l}\text { Yes - JARC and New } \\
\text { Freedom funds } \\
\text { administered by } \\
\text { NDDOT }\end{array}$ & $\begin{array}{l}\text { Section } 5307 \text { funds } \\
\text { administered by FTA }\end{array}$ \\
\hline $\begin{array}{l}\text { Bismarck Urban Area } \\
\text { and West Central } \\
\text { Region }\end{array}$ & $\begin{array}{l}\text { Bismarck Urban Area } \\
\text { and Southwest Region }\end{array}$ & $\begin{array}{c}\text { Yes - JARC and New } \\
\text { Freedom funds } \\
\text { administered by } \\
\text { NDDOT }\end{array}$ & $\begin{array}{l}\text { Section } 5311 \text { funds } \\
\text { administered by } \\
\text { NDDOT }\end{array}$ \\
\hline $\begin{array}{l}\text { Grand Fork Urban } \\
\text { Area }\end{array}$ & $\begin{array}{l}\text { Grand Forks Urban } \\
\text { Area and Northeast } \\
\text { Region }\end{array}$ & $\begin{array}{l}\text { Yes }- \text { JARC and New } \\
\text { Freedom funds } \\
\text { administered by } \\
\text { NDDOT }\end{array}$ & $\begin{array}{l}\text { Section } 5311 \text { funds } \\
\text { administered by } \\
\text { NDDOT }\end{array}$ \\
\hline $\begin{array}{l}\text { South Central Pilot } \\
\text { Region }\end{array}$ & $\begin{array}{l}\text { Southeast Region or } \\
\text { Transfer Personnel to } \\
\text { Northwest Region }\end{array}$ & $\begin{array}{l}\text { Yes }- \text { JARC and New } \\
\text { Freedom funds } \\
\text { administered by } \\
\text { NDDOT }\end{array}$ & $\begin{array}{l}\text { Section } 5311 \text { funds } \\
\text { administered by } \\
\text { NDDOT }\end{array}$ \\
\hline Not Applicable & Northwest Region & $\begin{array}{c}\text { No - no funds currently } \\
\text { being expended }\end{array}$ & $\begin{array}{l}\text { Section } 5311 \text { funds } \\
\text { administered by } \\
\text { NDDOT }\end{array}$ \\
\hline
\end{tabular}

As noted earlier, the job descriptions and regions assigned to each regional transit coordinator will be an ongoing work in progress. If it is ultimately determined that duties associated with the northwest region cannot be assigned to one or more of the existing regional coordinators, an additional coordinator will be needed for that region. It is also possible, however, that those duties could be assumed by one or more of the existing coordinators. It is envisioned, therefore, that the state will need no more than five transit coordinators. It is also possible, however, that fewer coordinators will eventually be needed.

\subsubsection{Regional Coordinator Qualifications and Job Functions - Statewide Coverage}

Regional transit coordinator qualifications and job duties relative to the two pilot regions were discuss earlier in Subsection 4.1.2 and summarized in Figure 4.1. As those discussions indicated, related qualifications and job duties are a work in progress and will undoubtedly change as local needs are identified and as they subsequently evolve. They may also vary from city to city and region to region, based on local needs. NDDOT's Transit Section will be a part of related deliberations and determinations, given that fact that it administers federal funds currently used to fund all the positions identified in Table 4.5. 
Initially, it is anticipated that the qualifications for additional regional coordinators to serve areas beyond the two pilot regions will mirror those previously outlined for the pilot regions. As indicated earlier, however, the Cities Area Transit coordinator will be handling related duties in both the Grand Forks urban area and the 10 counties in northeast North Dakota, and the Bis-Man coordinator will serve both the Bismarck-Mandan urban area and the 8 counties in the west central pilot region. Those positions' job duties will, therefore, have to be altered to reflect not only those recommended in Figure 4.1, but also those prescribed by Cities Area Transit and Bis-Man Transit.

As indicated earlier, the urban transit system in Fargo also has transit coordinator to coordinate local travel services and to facilitate personal mobility in the Fargo-West Fargo-Moorhead urban area. That position's job description will ultimately be dictated by whether it continues to focus strictly on the urban area or if its scope is expanded to include all the counties in southeast North Dakota.

\subsubsection{Budget and Funding Sources - Statewide Coverage}

As previously discussed, NDDOT's Transit Section currently has four contracts in place to provide transit coordination services in the state. These contracts provide coverage for the south central and west central pilot regions, the northeast region, and the Fargo urban area.

It is envisioned that the coordinators in the two pilot regions will eventually be able to expand their territories to include entire quadrants of the state. This expansion, plus the coverage currently in place in the northeast region, would leave only the northwest region without a regional transit coordinator. Coverage for that region could theoretically be accomplished without adding an additional coordinator, if the Fargo coordinator is able to also serve the southeast region and if that region's existing coordinator can be transferred to the northwest region.

Given the demands of the entire Fargo urban area and the shift in funding streams discussed earlier, it seems impractical to have the Fargo urban coordinator assume the additional duties associated with all of southeast North Dakota. Therefore, it may ultimately be necessary to hire one additional coordinator to serve the northwest region.

Cost estimates for regional transit coordinators for the two pilot regions were presented earlier in Table 4.1. Cost estimates related to expanding related services statewide, as described in the preceding paragraph, are presented in Tables 4.6 and 4.7. These cost estimates mirror those presented in Table 4.1, except for the Fargo position. That position's costs reflect the expenses currently associated with that position, plus 3\% annual inflation. Projected costs are also based on the expectation that Minnesota will no longer bear a portion of those costs if the position's duties are expanded to cover all of southeast North Dakota.

Table 4.6 is based on the assumption that the existing Fargo position is eventually expanded to encompass all of southeast North Dakota, and that the south central pilot region's coordinator would concurrently be reassigned to the Northwest region. It is also assume that the Fargo - southeast North Dakota position would be paid $50 \%$ with federal funds administered by NDDOT. The table does not reflect the other $50 \%$ that would be paid by Fargo using funds that it will receive directly from the FTA under MAP- 21 .

Table 4.7 assumes that the existing Fargo position will remain dedicated to that urban area and that an additional coordinator would be hired for the northwest region. Under this scenario, NDDOT would use its SAFETEA-LU allocations to fund the position initially, but once MAP-21 funds become available, it would be funded $100 \%$ without NDDOT-administered federal funding. It is assumed that a regional transit coordinator position will be created in the northwest region as early as 2014, depending on the availability of funding and other workload-related factor discussed earlier. 
Table 4.6 Regional Transit Coordination Budget - Four Coordinators Providing Statewide Coverage

\begin{tabular}{|c|c|c|c|c|c|}
\hline Expense Item/ & FY 2012-13 & FY 2013-14 & FY 2014-15 & FY 2015-16 & FY 2016-17 \\
\hline Federal Funding Source & SAFETEA-LU & SAFETEA-LU & SAFETEA-LU & MAP-21 & MAP-21 \\
\hline \multicolumn{6}{|l|}{ Salary and Benefits } \\
\hline South Central Pilot Region & 70,000 & 72,100 & $\$$ & $\$$ & $\$$ \\
\hline West Central Pilot Region & 70,000 & 72,100 & $\$$ & $\$$ & $\$$ \\
\hline Northeast Region & 70,000 & 72,100 & 74,300 & 76,700 & 79,000 \\
\hline Fargo Urban Area * & 70,000 & 72,100 & $\$$ & $\$$ & $\$$ \\
\hline Southeast Region + Fargo & $\$$ & $\$$ & 88,500 & 45,600 & 47,000 \\
\hline Southwest Region & $\$$ & $\$$ & 74,300 & 76,700 & 79,000 \\
\hline Northwest Region & $\$$ & $\$$ & 74,300 & 76,700 & 79,000 \\
\hline \multicolumn{6}{|l|}{ Travel and Training } \\
\hline South Central Pilot Region & 15,000 & 15,500 & $\$$ & $\$$ & $\$$ \\
\hline West Central Pilot Region & 15,000 & 15,500 & $\$$ & $\$$ & $\$$ \\
\hline Northeast Region & 15,000 & 15,500 & 16,000 & 16,400 & 16,900 \\
\hline Fargo Urban Area** & $\$$ & $\$$ & $\$$ & $\$$ & $\$$ \\
\hline Southeast Region + Fargo & $\$$ & $\$$ & 16,000 & 8,200 & 8,500 \\
\hline Southwest Region & $\$$ & $\$$ & 16,000 & 16,400 & 16,900 \\
\hline Northwest Region & $\$$ & $\$$ & 16,000 & 16,400 & 16,900 \\
\hline \multicolumn{6}{|l|}{ Office Equipment and Supplies } \\
\hline South Central Pilot Region & 10,000 & 5,200 & $\$$ & $\$$ & $\$$ \\
\hline West Central Pilot Region & 10,000 & 5,200 & $\$$ & $\$$ & $\$$ \\
\hline Northeast Region & 5,000 & 5,200 & 5,300 & 5,500 & 5,600 \\
\hline Fargo Urban Area** & $\$$ & $\$$ & $\$$ & $\$$ & $\$$ \\
\hline Southeast Region + Fargo & $\$$ & $\$$ & 5,300 & 2,700 & 2,800 \\
\hline Southwest Region & $\$$ & $\$$ & 5,300 & 5,500 & 5,600 \\
\hline Northwest Region & $\$$ & $\$$ & 5,300 & 5,500 & 5,600 \\
\hline Total Cost - All Positions & 350,000 & 350,500 & 396,600 & 352,300 & 362,800 \\
\hline Less: $20 \%$ Local Match & 70,000 & 70,100 & 79,300 & 70,500 & 72,600 \\
\hline Required Federal Funds - NDDOT & 280,000 & 280,400 & 317,300 & 281,800 & 290,200 \\
\hline \multicolumn{6}{|l|}{ * North Dakota's share of costs } \\
\hline$* *$ Short-term costs are included in & salary line ite m. & & & & \\
\hline
\end{tabular}


Table 4.7 Regional Transit Coordination Budget - Five Coordinators Providing Statewide Coverage

\begin{tabular}{|c|c|c|c|c|c|}
\hline Expense Item & FY 2012-13 & FY 2013-14 & FY 2014-15 & FY 2015-16 & FY 2016-17 \\
\hline Federal Funding Source & SAFETEA-LU & SAFETEA-LU & SAFETEA-LU & MAP-21 & MAP-21 \\
\hline \multicolumn{6}{|l|}{ Salary and Bene fits } \\
\hline South Central Pilot Region & 70,000 & 72,100 & $\$$ & $\$$ & $\$$ \\
\hline West Central Pilot Region & 70,000 & 72,100 & $\$$ & $\$$ & $\$$ \\
\hline Northeast Region & 70,000 & 72,100 & 74,300 & 76,700 & 79,000 \\
\hline Fargo Urban Area (ND share) & 70,000 & 72,100 & 74,300 & $\$$ & $\$$ \\
\hline Southeast Region & $\$$ & $\$$ & 74,300 & 76,700 & 79,000 \\
\hline Southwest Region & $\$$ & $\$$ & 74,300 & 76,700 & 79,000 \\
\hline Northwest Region & $\$$ & $\$$ & $\$$ & 76,700 & 79,000 \\
\hline \multicolumn{6}{|l|}{ Travel and Training } \\
\hline South Central Pilot Region & 15,000 & 15,500 & $\$$ & $\$$ & $\$$ \\
\hline West Central Pilot Region & 15,000 & 15,500 & $\$$ & $\$$ & $\$$ \\
\hline Northeast Region & 15,000 & 15,500 & 15,900 & 16,400 & 17,000 \\
\hline Fargo Urban Area* & $\$$ & $\$$ & $\$$ & $\$$ & $\$$ \\
\hline Southeast Region & $\$$ & $\$$ & 15,900 & 16,400 & 17,000 \\
\hline Southwest Region & $\$$ & $\$$ & 15,900 & 16,400 & 17,000 \\
\hline Northwest Region & $\$$ & $\$$ & $\$$ & 16,400 & 17,000 \\
\hline \multicolumn{6}{|l|}{ Office Equipment and Supplies } \\
\hline South Central Pilot Region & 10,000 & 5,200 & $\$$ & $\$$ & $\$$ \\
\hline West Central Pilot Region & 10,000 & 5,200 & $\$$ & $\$$ & $\$$ \\
\hline Northeast Region & 5,000 & 5,200 & 5,300 & 5,500 & 5,600 \\
\hline Fargo Urban Area* & $\$$ & $\$$ & $\$$ & $\$$ & $\$$ \\
\hline Southeast Region & $\$$ & $\$$ & 5,300 & 5,500 & 5,600 \\
\hline Southwest Region & $\$$ & $\$$ & 5,300 & 5,500 & 5,600 \\
\hline Northwest Region & $\$$ & $\$$ & $\$$ & 5,500 & 5,600 \\
\hline Total Cost - All Positions & 350,000 & 350,500 & 360,800 & 394,400 & 406,400 \\
\hline Less: $20 \%$ Local Match & 70,000 & 70,100 & 72,200 & 78,900 & 81,300 \\
\hline Required Federal Funds - NDDOT & 280,000 & 280,400 & 288,600 & 315,500 & 325,100 \\
\hline
\end{tabular}

* Associated costs include in salary line item. Amounts shown do not included Minnesota portion to total costs. 
Tables 4.6 and 4.7 are based on the projection that statewide coordination will be achieved no later than FY 2016-17. A comparison of the two tables indicates that, when fully implemented, the five coordinator scenario would cost only $\$ 35,000$ more than the four coordinator option, in terms of state-directed federal funding. Both options are within the funding limits projected earlier in Tables 4.2 and 4.3.

The five coordinator option is far more straightforward and provides coverage on both sides of the North Dakota-Minnesota border in the Fargo urban area. It would also provide better coverage to the southeast region. Given these facts and the relatively small price differential, it is recommended that NDDOT pursue the five coordinator option.

As indicated earlier in Subsection 4.1.3, it is estimated that MAP-21 will provide North Dakota with a net increase in rural 5311 funding of approximately $\$ 574,000$. If it is decided to fund transit coordinator positions with related administrative funds, which require no local match, the state's rural transit operators would still realize a net increase in funding of $\$ 249,000$ per year $(\$ 574,000$ - $\$ 325,000)$; an increase of $6.2 \%$ over current SAFETEA-LU funding.

As discussed earlier, it is also possible that NDDOT's transit staff may ultimately determine that the state can be adequately served with fewer regional transit coordinators. One such option might involve having a single coordinator provide related services to both the northwest and the southwest regions. As indicated in Table 4.4, these two regions have a total of 14 transit operators, the same as the northeast region. This scenario would reduce total coordinator-related costs by approximately $\$ 100,000$ per year.

\subsection{Recommendations Related to Other Project Tasks}

In addition to the regional transit coordinator recommendations discussed earlier in this chapter, it is recommended that NDDOT's Transit Section use its existing central office transit staff or contractors to undertake additional efforts to further facilitate coordination and effective and efficient local transit operations across North Dakota. Related activities include the operations of local transit advisory boards, more uniform policies and fares, the publicizing of existing transit services, the use of performance measures to monitor operations and to encourage related modifications, and the documentation of ongoing coordination-related achievments and benefits. Specific recommendations regarding these items are presented in the remaining subsections of this report.

\subsubsection{Encourage Local Advisory Boards}

Section 3.1 discussed the value of having local transit advisory committees whose members represent a broad cross section of the community - transit users, advocates, the business community, etc. If effectively utilized, these committees can help local transit managers stay current with the evolving personal mobility needs of the community and determine the effectiveness of local transit services.

As discussed in Subsection 3.1.1, SURTC researchers worked with NDDOT's transit personnel to develop a corresponding set of guidelines regarding the establishment of local advisory boards and a template set of bylaws that local operators could use to formalize the establishment and operations of such boards. These items are presented in Appendix A.

At the request of NDDOT's transit staff, SURTC presented these guidelines and the template bylaws to a January 2012 meeting of all the state's transit managers. It is recommended that NDDOT's Transit Section monitor subsequent operator actions and take steps to further encourage the creation and effective operations of local transit advisory boards. Newly hired regional transit coordinators can play a vital role in this process. 
Coordination begins at the local level and having the right entities involved in the need identification process is essential. Local advisory boards are a cost-efficient and effective way of facilitating that process.

\subsubsection{Continue Quarterly Meetings and Promote Operator Awareness}

The quarterly meetings that were held with each region's transit managers throughout this project were an effective way to increase operator awareness of each other's operations. If future meetings are to be conducted, managers stressed the need for meaningful discussion topics and scheduling meetings to coincide with other meeting, thereby reducing overall time requirements.

It is recommended that these meetings be continued and that special efforts be made to ensure that the meetings are, in fact, meaningful and productive. It is envisioned that these meetings would be held in conjunction with statewide quarterly meetings called by NDDOT's Transit Section and that each region's regional transit coordinator would prepare corresponding agendas and preside over the meetings.

\subsubsection{Promote Increased Uniformity - Policies, Services, Practices, and Fares}

Two of this project's tasks addressed the need to promote increased uniformity within the state's transit community. This uniformity involved matters such as policies, services, operating practices, and fares.

In response to these tasks, SURTC worked with NDDOT's transit staff to develop several guidelines for possible dissemination to the state's transit operators, along with a library of industry best practices operating policies that local operators may use when they need policies to address evolving issues. SURTC also worked with NDDOT's transit staff to develop a template rider's guide that most of the regions' operators adopted to publicize matters such as operating hours, weather cancellations, acceptable wait times for riders, frequently asked questions, and operator policies.

A related resource library has been posted on SURTC's website, and it is recommended that NDDOT's Transit Section either post these materials on its own website or create a related link to provide operators throughout the state with another way to access corresponding information.

Regarding fares, Subsection 3.2.3 indicated that perhaps the most notable lack of uniformity among the regions' transit systems concerned fares. Local one-way fares range $\$ .50$ to $\$ 2.50$ and long-distance fares over similar routes vary from less than $\$ .04$ per mile to $\$ .175$ per mile. These variances are not unique to the two pilot regions.

These variances inhibit coordination because passengers will be reluctant to use an alternate service if the related fare is significantly higher than they might otherwise have to pay. As indicated in Subsection 3.2.3, the regions' transit managers stated that it is difficult to adjust fares because their local governing boards are reluctant to make drastic changes, fearing that their patrons may be unwilling or unable to pay a greater share of the actual costs associated with providing related services.

NDDOT's Transit Section has attempted to educate operators regarding methodologies associated with determining the actual costs associated with providing various segments of their existing services, as well as those that might be incurred by providing proposed services. A related cost allocation workshop was held November 16-17, 2011, in Bismarck. Attendance by state transit managers was mandatory.

Despite these efforts, SURTC researchers did not observe any major modifications to existing fare structures during the course of this project. NDDOT's transit staff may need to take additional, stronger approaches to effectuate significant fare reform. Tying federal program grants to desired cost recovery 
goals might give local managers the ammunition they need to convince their local boards that fare adjustments are appropriate. Related adjustments could be made incrementally over a period of months, or longer, in order to diminish the immediate impacts on patrons.

\subsubsection{Establish/Update and Maintain Local Websites}

Subsection 3.3.1 outlined efforts that were taken as a part of this project to create or enhance the websites of the regions' local transit systems. Seven of the regions' eight operators accepted related offers to enhance their Internet presence. The resulting sites are attractive, comprehensive, easy to use, and include current information on routes, fares, schedules, rider's guides, current policies, etc.

In most instances, these sites use a web-builder program available through the National Rural Transportation Assistance Program that was specifically designed for transit organizations. The resulting sites may be revised internally by the local operators, plus they are free to operate.

These sites should provide a greatly-expanded array of information for riders and caregivers, such as children of elderly parents, social service advocates of disabled individuals, or other transit service providers. These sites also include a link to NDDOT's transit site which, in-turn provides information and access to the sites of North Dakota's other transit service providers.

The regions' transit operators should be strongly encouraged to keep their sites current. The regions' new transit coordinators can play an active role in this process. NDDOT's Transit Section may also want to provide the transit operators in other regions of the state with the same opportunity to have sites created for them, or to have their existing sites enhanced with related improvements.

\subsubsection{Enhance NDDOT's Transit Website}

In addition to working with the regions' individual transit managers to create or enhance their local websites, SURTC also worked with NDDOT's transit staff to enhance the transit portion of the department's website. The resulting site is user friendly and provides easy access to current information on not only local transit services, but also intercity bus and local taxi services throughout the state.

In addition to information regarding transit, bus, and taxi services, efforts were also made to enhance the portion of the site that provides information to the state's transit managers. Related postings include newsletters, application and compliance forms, and template policies.

It is recommended that NDDOT's transit staff make a concerted effort to keep related information current and to be watchful for other postings that might enhance personal mobility and operator access to useful information.

\subsubsection{Publicize and Promote Transit Services}

In addition to the Internet-related efforts discussed in the two preceding subsections, it is recommended that NDDOT's Transit Section work with the state's transit managers to develop local and statewide campaigns to promote the awareness and use of transit services in North Dakota. As discussed in Subsection 3.3.3, related efforts might include radio and television public service announcements, newspaper advertisements, promotional posters and flyers, direct mailings, and personal presentations to local agencies and service organizations. Special campaigns related to events such as National Public Transit Week might also be considered. Local campaigns might be encouraged and facilitated by each region's regional transit coordinator. 
To assist NDDOT's Transit Section and local transit operators with related efforts, SURTC compiled and presented the department with information on transit-publicizing initiatives that have been used successfully by other communities and states. Hopefully this information will be used by NDDOT's transit staff, regional transit coordinators, and local operators to promote the use of transit in the state and to enhance overall personal mobility.

\subsubsection{Monitor Service Provider Operations}

The operator-specific discussions in Chapter 2 included numerous performance measures. These measures, when tracked over time, can provide meaningful insights regarding operator efficiencies and effectiveness. They can also be used to establish goals related to future operations.

It is recommended that NDDOT's Transit Section continue collecting related underlying data, and that performance measures be calculated and discussed with transit managers and their advisory boards. The end result should be more well-informed boards, better decision making, and more effective and efficient operations. Each region's regional transit coordinator may play a key role in related monitoring and subsequent presentations.

\subsubsection{Document Coordination-related Achievements and Benefits}

NDDOT's transit staff and SURTC researchers worked closely during this project to identify means to promote and measure the reliability of local transit services and to measure the operational impacts of coordination. Related measures were discussed in Subsection 3.4.1 and summarized in Table 3.3. SURTC also worked with NDDOT's Transit Section to develop guidelines and a template policy that local operators might use to establish their own standards regarding service reliability. Those guidelines and the template policy are presented in Appendix C. It is recommended that NDDOT's Transit Section encourage the adoption of a related policy by all the state's transit operators.

\subsubsection{Monitor Operators' Implementation of Service Modifications}

The final sections of Chapter 3 discussed a series of coordination-related service modifications that were discussed and agreed to in mid-2012 face-to-face meetings involving various subsets of the regions' transit managers. Some of these changes were to be implemented immediately, while others might need to be phased in gradually. The status of these changes should be monitored by each region's regional transit coordinator and follow-up meetings should be held with the respective managers to assess related impacts and opportunities for further efficiency gains and service enhancements. 


\section{APPENDIX A:}

ADVISORY BOARD GUIDELINES AND TEMPLATE BYLAWS 


\section{NDDOT Guidelines on Local Planning and Coordination}

NDDOT encourages all publicly-supported transit providers to develop and utilize procedures that:

Identify local personal mobility needs

Provide transit services that are safe, efficient, effective, reliable, and responsive to identified needs

Coordinate local transit services with those provided by commercial and other publicly-supported transit services within their service area and region

Related need identification, service design, and coordination processes can be facilitated via the existence and meaningful operations of a governing board, a local transit advisory board/coordinating council, or other mechanisms. The following sections provide guidance concerning related operating practices.

\section{Single Service Providers}

Some North Dakota transit operators are single service providers. Their primary function is the provision of transit services. The governing board of a single service provider may pursue the fulfillment of the goals outlined in the previous section. In doing so, the board should be comprised of members from throughout the provider's service area and should include representatives from:

Human service/social service agencies

Transit users/advocates

Businesses/local government/economic development organizations

Other entities as deemed appropriate by the board

Board members should not be an employee of the transit system or be related to a system employee.

Local governing boards that fulfill related functions should meet at least quarterly and should:

Help identify unmet personal mobility needs of area residents and facilitate the development of transit services that are responsive to those needs

Advocate for high quality transit services which are safe, efficient, effective, reliable, and responsive to the mobility needs of area residents

Help facilitate public awareness of available public transit services within the area

Encourage and facilitate the coordination of its transit services with those of commercial and other publicly-supported transit services within the service area and region

Actively provide guidance regarding planning, policy, and other matters related to the provision of transit services

A copy of the board's bylaws or other forms of governance should be filed with NDDOT's Transit Section, along with a list of current board members, their addresses, and who each member represents. Minutes of all meetings should be prepared and maintained and be available to NDDOT upon request. 
Alternatively, the governing board of a single service provider may choose to establish a separate transit advisory board/coordinating council. If so, that board/council should be structured and should function as outlined above and should serve in an advisory capacity to the governing board. Such boards/councils should meet at least semi-annually. Upon request, NDDOT will provide a governing board with a template of related advisory board/coordinating council bylaws for its possible use.

\section{Multi-Service Providers}

Multi-service providers provide, not only transit services, but other services related to functions such as municipal operations, senior meal sites, home delivered meals, etc. The governing board of a multiservice provider oversees the provision of various services, one of which is transit.

The governing board of a multi-service provider may either establish a separate transit advisory board/coordinating council as outlined in the preceding section or provide NDDOT with ongoing documentation of its efforts to satisfy the need identification, service design, and coordination goals of these guidelines. Related filings should be made with NDDOT's Transit Section on an annual basis and should include:

Documentation of contacts made with human service/social service agencies, transit users/advocates, businesses/local government/economic development organizations, and other entities in the service area to discuss existing transit services and to solicit input regarding any unmet personal mobility needs

Efforts taken to provide transit services that are responsive to identified needs

Efforts taken to create public awareness of available transit services within the area

Efforts taken to coordinate local transit services with those of commercial and other publiclysupported transit services within the service area and region

Related filings should also be presented to the service provider's governing board on an ongoing basis. It is the responsibility of the governing board to ensure that:

Local personal mobility needs are adequately identified

Local transit services are safe, efficient, effective, reliable and responsive to identified needs

Local transit services are coordinated with those provided by commercial and other publiclysupported transit services within the service area and region

Questions regarding these guidelines should be directed to NDDOT's Transit Section. 


\section{Bylaws}

\section{Transit Advisory Board/Coordinating Council}

\section{Article I: Name}

The name of this organization shall be the Board/Coordinating Council, hereinafter called Board/Council. Transit Advisory

\section{Article II: Purpose}

The purposes of the Board/Council are to:

Help identify unmet personal mobility needs of area residents and facilitate the development of transit services that are responsive to those needs.

Advocate for high quality transit services which are safe, efficient, effective, reliable, and responsive to the mobility needs of area residents.

Help facilitate public awareness of available public transit services within the area.

Encourage and facilitate the coordination of (insert provider's name)'s services with those of commercial and other publicly-supported transit services within the service area and region.

Advise the (insert name of governing board) on planning, policy, and other matters related to the provision of transit services by ___ (insert name of transit service provider) , hereinafter called

\section{Article III: Membership}

The Board/Council shall be comprised of members from throughout name)'s_ service area and shall include representatives from: (insert provider's

Human service/social service agencies

Transit users/advocates

Businesses/local government/economic development organizations

Other entities as deemed appropriate by the ___ (insert name of governing board)

Board/Council members shall not be an employee of the transit system or be related to a system employee. The membership of the Board/Council shall not exceed___e.g., 9)__ people. Individuals shall be appointed to the Board/Council by the ___ (insert name of governing board) _. Initial appointments shall be staggered to provide that approximately one-third of the members are for one-year terms, one-third for two-year terms, and one-third for three-year terms. Thereafter, all appointments shall be for three-year terms. All appointments shall take effect prior to the meeting at which elections will be held. 
A Board/Council member who does not attend three consecutive regularly scheduled meetings and whose absence does not receive prior excused status from the chairperson, shall be removed from the Board/Council.

All vacancies that occur prior to the end of a term in office shall be filled by a majority vote of the members present at a duly called Board/Council meeting. The individual elected to fill a vacancy shall serve in that capacity for the remainder of the involved term of office.

A Board/Council member who represents a human service/social service agency may designate a substitute from that agency to attend any Board/Council meeting in his or her stead. That Board/Council member will be counted as present for that meeting.

\section{Article IV: Officers}

The Board/Council shall annually elect a chairperson, a vice-chairperson, and a secretary from within the members of the Board/Council. An individual receiving a majority of the votes shall be deemed elected and shall assume office immediately following the conclusion of that meeting. In the event that no person receives a majority of the votes cast, votes shall then be cast for the top two vote recipients.

The chairperson shall preside over all meetings of the Board/Council; appoint committees, as appropriate; and serve as an ex officio member of all committees.

The vice chairperson shall assist the chairperson in the execution of that office and shall preside at meetings in the event of the absence of the chairperson.

The secretary shall take and maintain copies of the minutes of all Board/Council meetings and notify members of upcoming meetings. Meeting minutes shall be prepared within ten days after a meeting, sent

to the (insert name of governing board) , and be available upon request by the North Dakota Department of Transportation.

\section{Article V: Meetings \& Quorum}

The Board/Council shall meet at least ___ (quarterly, tri-annually, semi-annually, etc.) _ , in addition to special meetings convened by the chairperson or at the request of _e.g., 5)_ Board/Council members.

The secretary shall give written notice of each regular meeting at least one week prior to the meeting date. In the event that a special meeting is called, the secretary shall give written and verbal notice to all Board/Council members at least 24 hours in advance of the meeting. Written notices may be sent electronically. Members may attend meetings either in person or telephonically.

Fifty percent of the members of the Board/Council shall constitute a quorum. Proxy voting is not permitted. 


\section{Article VI: Amendments and Parliamentary Procedure}

These bylaws may be amended or repealed, in whole or in part, by a majority vote of the (insert name of governing board) . A copy of these bylaws and all subsequent amendments shall be available for review upon request by the North Dakota Department of Transportation. All proceedings shall be governed by the latest edition of "Roberts Rules of Order".

Bylaws adopted: 


\section{APPENDIX B:}

TRANSIT COORDINATION SELF-ASSESSMENTS 
Transit System: Dickey County Transportation

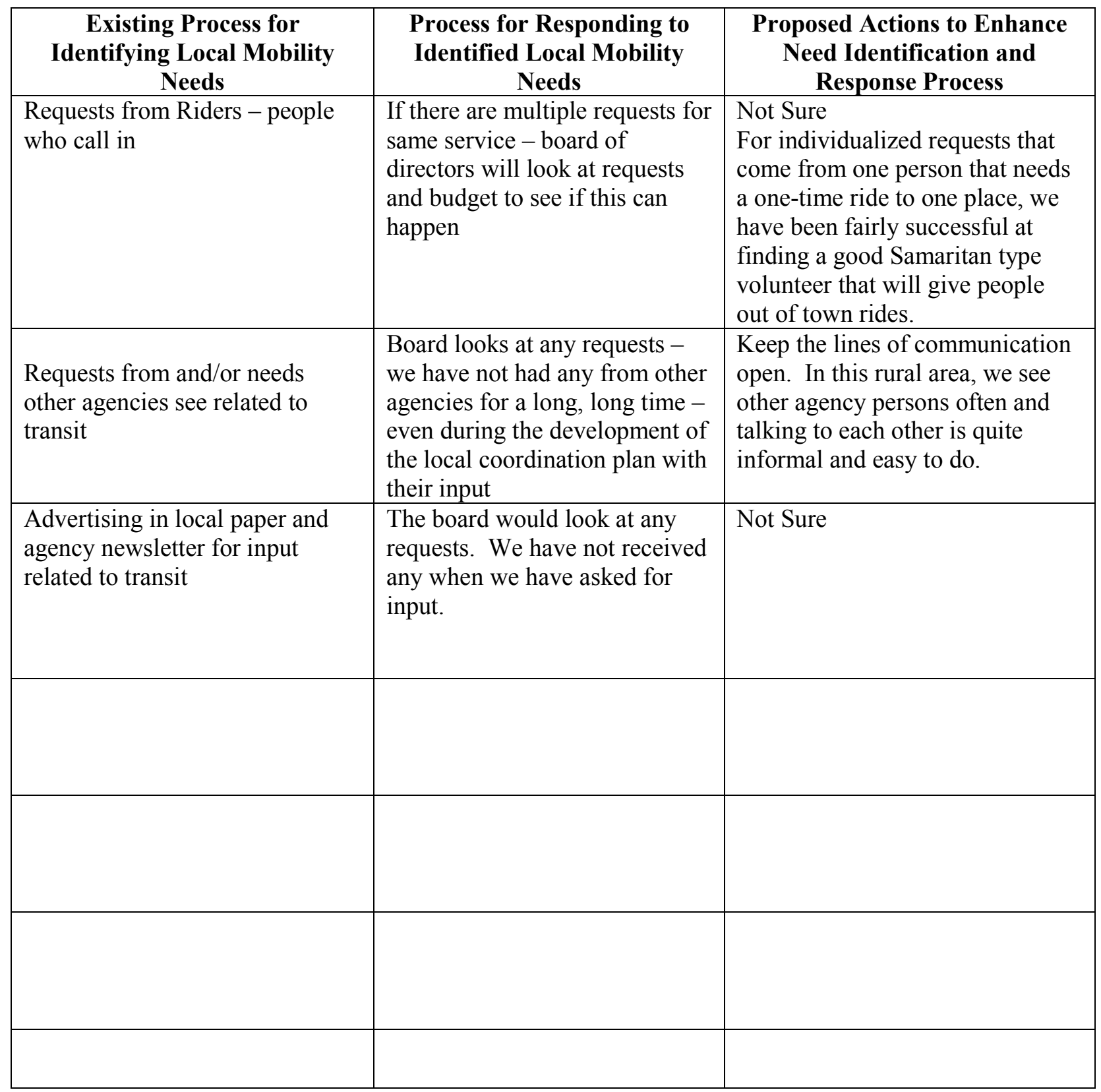




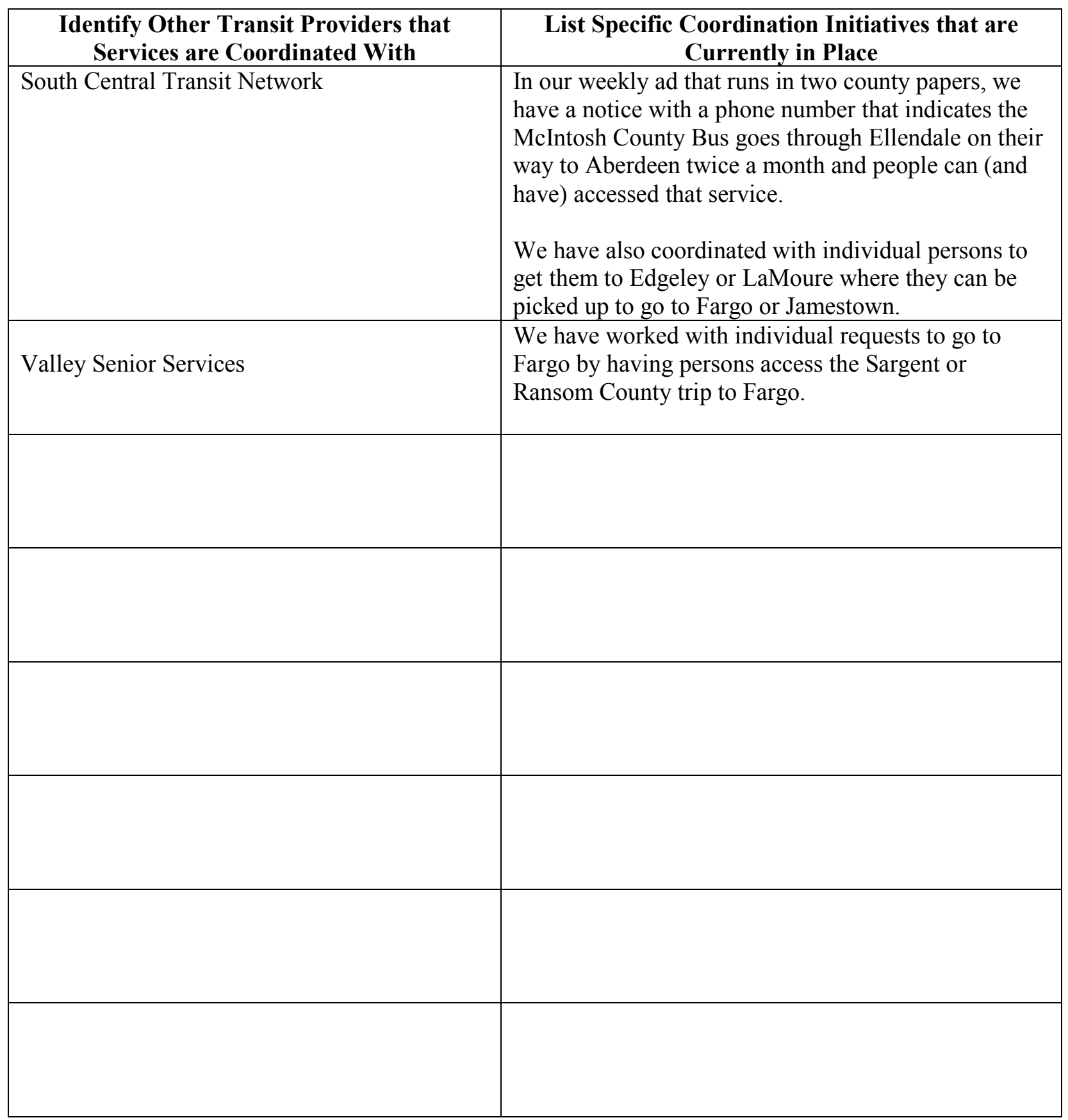




\begin{tabular}{|l|l|}
\hline $\begin{array}{l}\text { Opportunities for Coordination with Other } \\
\text { Transit Providers }\end{array}$ & $\begin{array}{c}\text { Proposed Modifications to Coordinate Services } \\
\text { with Other Transit Providers }\end{array}$ \\
\hline $\begin{array}{l}\text { Not sure what those would be or who those } \\
\text { could be with }\end{array}$ & $\begin{array}{l}\text { Will gladly coordinate }- \text { is there somebody to } \\
\text { coordinate with? }\end{array}$ \\
\hline & \\
\hline & \\
\hline & \\
\hline & \\
\hline & \\
\hline
\end{tabular}


Transit System:

Glen Ullin City Transportation

\begin{tabular}{|l|l|l|}
\hline $\begin{array}{c}\text { Existing Process for } \\
\text { Identifying Local Mobility } \\
\text { Needs }\end{array}$ & $\begin{array}{c}\text { Process for Responding to } \\
\text { Identified Local Mobility } \\
\text { Needs }\end{array}$ & $\begin{array}{c}\text { Proposed Actions to Enhance } \\
\text { Need Identification and } \\
\text { Response Process }\end{array}$ \\
\hline Director, driver, \& mayor & $\begin{array}{l}\text { If need or want is there, \& } \\
\text { driver is available, then a trip is } \\
\text { scheduled. }\end{array}$ & $\begin{array}{l}\text { To establish a Board of Directors. } \\
\text { Mayor \& driver will both serve } \\
\text { on board. }\end{array}$ \\
\hline & $\begin{array}{l}\text { Driver, mayor, \& director } \\
\text { receive calls from community. }\end{array}$ & \\
\hline & & \\
\hline & & \\
\hline & & \\
\hline & & \\
\hline & & \\
\hline & & \\
\hline & & \\
\hline & & \\
\hline & & \\
\hline & & \\
\hline
\end{tabular}




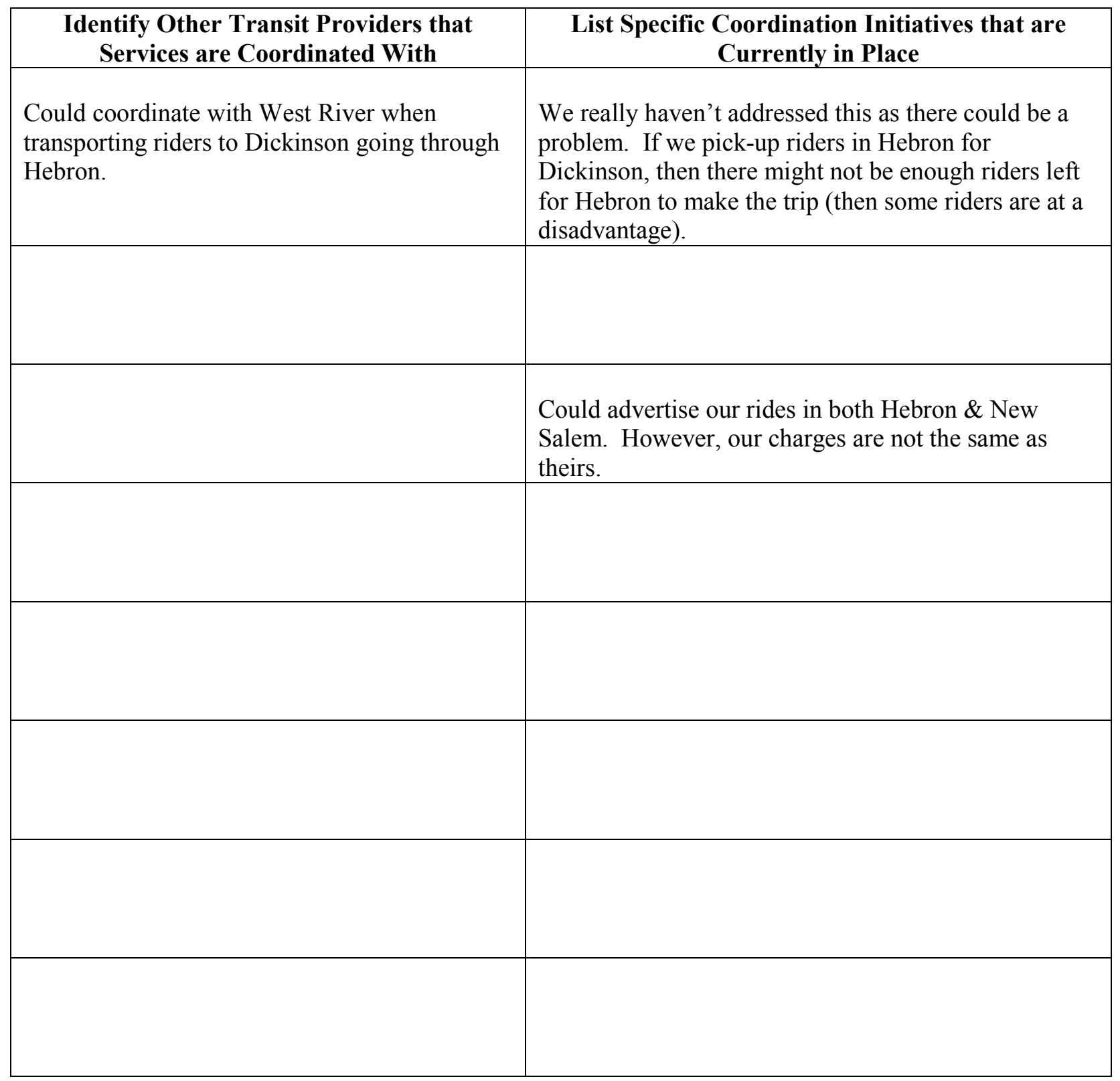




\begin{tabular}{|l|l|}
\hline $\begin{array}{c}\text { Opportunities for Coordination with Other } \\
\text { Transit Providers }\end{array}$ & $\begin{array}{c}\text { Proposed Modifications to Coordinate Services } \\
\text { with Other Transit Providers }\end{array}$ \\
\hline None & $\begin{array}{l}\text { With Elgin Hospital/clinic to transport women from } \\
\text { Hebron \& Glen Ullin to Elgin for "Mammogram on } \\
\text { the Move." This is scheduled for 4 times this year. }\end{array}$ \\
\hline & \\
\hline & \\
\hline & \\
\hline & \\
\hline & \\
\hline & \\
\hline & \\
\hline
\end{tabular}




\begin{tabular}{|c|c|c|}
\hline $\begin{array}{c}\text { Existing Process for } \\
\text { Identifying Local Mobility } \\
\text { Needs } \\
\end{array}$ & $\begin{array}{c}\text { Process for Responding to } \\
\text { Identified Local Mobility } \\
\text { Needs } \\
\end{array}$ & $\begin{array}{c}\text { Proposed Actions to Enhance } \\
\text { Need Identification and } \\
\text { Response Process }\end{array}$ \\
\hline $\begin{array}{l}\text { Community networking, } \\
\text { quarterly meetings, public } \\
\text { input meetings, advertising in } \\
\text { newspaper, magnets, flyers, } \\
\text { brochure, website, etc. }\end{array}$ & $\begin{array}{l}\text { Determining the needs, } \\
\text { providing the service or } \\
\text { referring them to other } \\
\text { agency }\end{array}$ & $\begin{array}{l}\text { Determine and review contacts } \\
\text { with other agencies needing } \\
\text { transportation }\end{array}$ \\
\hline $\begin{array}{l}\text { Coordinate with local medical } \\
\text { facilities for transportation }\end{array}$ & $\begin{array}{l}\text { Holding public meetings on } \\
\text { riders' needs }\end{array}$ & Local city wide mailings \\
\hline $\begin{array}{l}\text { Coordinate with social } \\
\text { services programs and group } \\
\text { homes for transportation }\end{array}$ & $\begin{array}{l}\text { Reviewing alternative transit } \\
\text { agencies schedules to help } \\
\text { the rider be more mobile }\end{array}$ & Survey the public \\
\hline $\begin{array}{l}\text { Coordinate with senior living } \\
\text { centers and community senior } \\
\text { programs for meal } \\
\text { transportation and daily living } \\
\text { needs }\end{array}$ & $\begin{array}{l}\text { Determine if extending work } \\
\text { hours are needed, and if } \\
\text { additional funding is } \\
\text { available to cover the costs }\end{array}$ & Advertise in church bulletins \\
\hline $\begin{array}{l}\text { Coordinate with park and rec } \\
\text { program for transportation to } \\
\text { activities }\end{array}$ & $\begin{array}{l}\text { If more local mobility needs } \\
\text { are needed, research grants } \\
\text { and additional funding to } \\
\text { determine extra service hours }\end{array}$ & $\begin{array}{l}\text { More outreach to needed } \\
\text { seniors citizens }\end{array}$ \\
\hline $\begin{array}{l}\text { Coordinate with parents for } \\
\text { transportation to preschool, } \\
\text { Head Start, school, etc. }\end{array}$ & $\begin{array}{l}\text { Focus on more fundraising } \\
\text { and joint efforts between } \\
\text { local businesses and Hazen } \\
\text { Busing. Finding sponsors for } \\
\text { more transportation } \\
\text { opportunities }\end{array}$ & $\begin{array}{l}\text { Director meets with Seniors for } \\
\text { lunch and opens more one on } \\
\text { one contact with riders }\end{array}$ \\
\hline $\begin{array}{l}\text { Coordinate with Oliver- } \\
\text { Mercer special-ed for } \\
\text { transportation needs }\end{array}$ & & $\begin{array}{l}\text { Keep the communication open } \\
\text { between riders and business } \\
\text { owners, churches, medical } \\
\text { facilities, residents, etc. }\end{array}$ \\
\hline
\end{tabular}




\begin{tabular}{|l|l|}
\hline \multicolumn{1}{|c|}{$\begin{array}{c}\text { Identify Other Transit Providers that } \\
\text { Services are Coordinated With }\end{array}$} & \multicolumn{1}{c|}{$\begin{array}{c}\text { List Specific Coordination Initiatives that are } \\
\text { Currently in Place }\end{array}$} \\
\hline Glen Ullin Transit & $\begin{array}{l}\text { We advertise our local schedule in Hazen, Beulah, } \\
\text { Center, Stanton, Pick City and Washburn. Flyers are } \\
\text { put up and drivers make contact }\end{array}$ \\
\hline West River Transit - Beulah & $\begin{array}{l}\text { Coordinate with Mclean-Mercer Commission on } \\
\text { Aging for free transportation to Senior Center for } \\
\text { noon meals }\end{array}$ \\
\hline West River Transit - Center & $\begin{array}{l}\text { Coordinate with Knife River Group Home for job } \\
\text { related transportation of residents }\end{array}$ \\
\hline & $\begin{array}{l}\text { Coordinate with riders in Center and Stanton on trips } \\
\text { to Bismarck (weekly) }\end{array}$ \\
\hline & $\begin{array}{l}\text { Coordinate with Hazen Park and Rec for } \\
\text { transportation to summer activities }\end{array}$ \\
\hline & \\
& \\
\hline
\end{tabular}




\begin{tabular}{|l|l|}
\hline $\begin{array}{c}\text { Opportunities for Coordination with Other } \\
\text { Transit Providers }\end{array}$ & \multicolumn{1}{|c|}{$\begin{array}{c}\text { Proposed Modifications to Coordinate Services } \\
\text { with Other Transit Providers }\end{array}$} \\
\hline $\begin{array}{l}\text { Bis-Man Transit \& West River in } \\
\text { Bismarck/Mandan area }\end{array}$ & $\begin{array}{l}\text { Identify the other agencies for riders that visit on a } \\
\text { weekly basis. }\end{array}$ \\
\hline Elder Care in Dickinson & $\begin{array}{l}\text { Identify the other agencies for riders that visit on our } \\
\text { monthly visit. }\end{array}$ \\
\hline West River Transit & $\begin{array}{l}\text { Coordinate long distance trips to Bismarck and } \\
\text { Dickinson }\end{array}$ \\
\hline Work with West River and City of Beulah & $\begin{array}{l}\text { Coordinate more local transit in the Beulah area; for } \\
\text { day cares, job access, head start, and local needed } \\
\text { daily transportation when West River is on long } \\
\text { distance routes or not available to respond }\end{array}$ \\
\hline & $\begin{array}{l}\text { Need to assess the cost involved with coordination. } \\
\text { (Available funding, grants, or other funding sources). } \\
\text { Needs to be cost effective }\end{array}$ \\
\hline $\begin{array}{l}\text { More advertising - public forums on coordination will } \\
\text { be necessary for the public to buy-in on the idea }\end{array}$ \\
\hline
\end{tabular}


Transit System: $\quad$ James River Senior Citizen's Public Transit

\begin{tabular}{|c|c|c|}
\hline $\begin{array}{c}\text { Existing Process for } \\
\text { Identifying Local Mobility } \\
\text { Needs }\end{array}$ & $\begin{array}{c}\text { Process for Responding to } \\
\text { Identified Local Mobility } \\
\text { Needs }\end{array}$ & $\begin{array}{c}\text { Proposed Actions to Enhance } \\
\text { Need Identification and } \\
\text { Response Process }\end{array}$ \\
\hline Community n etworking & $\begin{array}{l}\text { Determining needs, } \\
\text { providing the service or } \\
\text { referring to another agency. }\end{array}$ & $\begin{array}{l}\text { Determining if we have made } \\
\text { contact with all agencies } \\
\text { needing transportation }\end{array}$ \\
\hline $\begin{array}{l}\text { Community a wareness of other } \\
\text { agency needs. Round table } \\
\text { discussion with agencies in } \\
\text { need of transportation }\end{array}$ & $\begin{array}{l}\text { Determining the needs of the } \\
\text { agencies, making plans and } \\
\text { arrangements for needs, } \\
\text { providing the service, or } \\
\text { making referrals to another } \\
\text { transit agency }\end{array}$ & $\begin{array}{l}\text { Meeting more often if that is } \\
\text { workable for all agencies } \\
\text { involved }\end{array}$ \\
\hline $\begin{array}{l}\text { Knowing all local agency } \\
\text { contacts. Building a working } \\
\text { relationship with the other local } \\
\text { agencies that work with the } \\
\text { same individuals that we } \\
\text { provide transportation to. }\end{array}$ & $\begin{array}{l}\text { Holding meetings throughout } \\
\text { the year with the agency } \\
\text { contacts to determine the } \\
\text { needs for client services }\end{array}$ & $\begin{array}{l}\text { Conducting a survey with } \\
\text { agencies to see if we are on } \\
\text { target with the needs of all } \\
\text { agencies involved }\end{array}$ \\
\hline $\begin{array}{l}\text { Coordination with local } \\
\text { churches to provide weekend } \\
\text { transportation for their } \\
\text { parishioners }\end{array}$ & $\begin{array}{l}\text { Contact the churches and } \\
\text { obtain the current schedules } \\
\text { for worship. Making } \\
\text { arrangements for billing of } \\
\text { rides }\end{array}$ & $\begin{array}{l}\text { Advertising in the church } \\
\text { newsletters. Contacting the } \\
\text { church office making sure we } \\
\text { are meeting the needs of } \\
\text { Sunday worship }\end{array}$ \\
\hline $\begin{array}{l}\text { Coordination with local } \\
\text { nursing homes to provide } \\
\text { weeknight and weekend } \\
\text { travels for their residents }\end{array}$ & $\begin{array}{l}\text { Contacting the nursing home } \\
\text { staff for arrangements for out } \\
\text { of town medical travel needs } \\
\text { and weekend fellowship } \\
\text { requests for nursing home } \\
\text { clients }\end{array}$ & $\begin{array}{l}\text { Contacting the local } \\
\text { Administrator making sure we } \\
\text { as a transit provider are meeting } \\
\text { the needs of the nursing home } \\
\text { residents }\end{array}$ \\
\hline $\begin{array}{l}\text { Coordination with local } \\
\text { housing units for transit needs } \\
\text { for their clients with disabilities } \\
\text { for work and pleasure rides }\end{array}$ & $\begin{array}{l}\text { Working with the staff at } \\
\text { Alpha Opportunities and } \\
\text { Progress Enterprises for all } \\
\text { transportation needs for their } \\
\text { clients }\end{array}$ & $\begin{array}{l}\text { Contacting the management } \\
\text { staff of the rider with } \\
\text { disabilities making sure that } \\
\text { we are meeting the needs for } \\
\text { work and pleasure }\end{array}$ \\
\hline
\end{tabular}




\begin{tabular}{|l|l|}
\hline \multicolumn{1}{|c|}{$\begin{array}{c}\text { Identify Other Transit Providers that } \\
\text { Services are Coordinated With }\end{array}$} & \multicolumn{1}{c|}{$\begin{array}{c}\text { List Specific Coordination Initiatives that are } \\
\text { Currently in Place }\end{array}$} \\
\hline $\begin{array}{l}\text { South Central Transit in Valley City } \\
\text { Pat Hansen }\end{array}$ & $\begin{array}{l}\text { James River coordinating with SC on days that } \\
\text { JR does not travel (Thursday)taking riders over at } \\
\text { 6am to get on VC bus and going back at end of } \\
\text { day to bring riders back to Jamestown. }\end{array}$ \\
\hline $\begin{array}{l}\text { Benson County Transit } \\
\text { Sue Fossen }\end{array}$ & $\begin{array}{l}\text { Wells/Sheridan coordinating with Benson Transit } \\
\text { for Wells/Sheridan out of town travels to Minot and } \\
\text { Bismarck due to the fact new bus had not arrived } \\
\text { and old bus was not safe to travel }\end{array}$ \\
\hline $\begin{array}{l}\text { Jamestown Taxi Service } \\
\text { Doug Fogerud }\end{array}$ & $\begin{array}{l}\text { James River Transit works with the local cab } \\
\text { company on a weekly basis providing cab name and } \\
\text { number to riders seeking a more one on one service } \\
\text { for shopping needs requesting entering of the home. } \\
\text { Leaving available the bar crowd hours for the local } \\
\text { cabs. Referrals made to taxi }\end{array}$ \\
\hline $\begin{array}{l}\text { Local Nursing Home Transportation services } \\
\text { for nursing home residents. Counties of }\end{array}$ & $\begin{array}{l}\text { Working with Nursing home providers seeking } \\
\text { Week night and weekend transportation for their } \\
\text { residents. Rides usually provided for out of town } \\
\text { medical appointments as nursing homes do not } \\
\text { travel out of town with their residents. They seek } \\
\text { local transit provider for those services. }\end{array}$ \\
\hline Anne Carlsen School for Children & $\begin{array}{l}\text { Coordination week night and weekend travel } \\
\text { for the children from the Anne Carlsen Center. } \\
\text { They provide weekday travel for the children, } \\
\text { seeking our services for other travel needs. }\end{array}$ \\
\hline
\end{tabular}




\begin{tabular}{|l|l|}
\hline \multicolumn{1}{|c|}{$\begin{array}{c}\text { Opportunities for Coordination with } \\
\text { Other Transit Providers }\end{array}$} & $\begin{array}{l}\text { Proposed Modifications to Coordinate Services } \\
\text { with Other Transit Providers }\end{array}$ \\
\hline $\begin{array}{l}\text { Kidder County /James River } \\
\text { Renee Price }\end{array}$ & $\begin{array}{l}\text { Advertising of our services in this community to } \\
\text { inform the riders of our service coming through } \\
\text { their community on certain days and travel into } \\
\text { Bismarck }\end{array}$ \\
\hline $\begin{array}{l}\text { Kidder County/Wells Sheridan } \\
\text { Renee Price } \\
\text { On days that the Wells Sheridan bus comes } \\
\text { from Harvey and meets up on Interstate to } \\
\text { head to Bismarck }\end{array}$ & $\begin{array}{l}\text { Advertising of our services in this community to } \\
\text { inform the local riders of our services coming } \\
\text { through their community and going on into } \\
\text { Bismarck }\end{array}$ \\
\hline $\begin{array}{l}\text { South Central Transit } \\
\text { Pat Hansen }\end{array}$ & $\begin{array}{l}\text { Advertising of our services in this community. } \\
\text { Working with the South Central staff on days and } \\
\text { times that we travel to Fargo and possibly picking up } \\
\text { any extra riders. }\end{array}$ \\
\hline $\begin{array}{l}\text { West River Transit } \\
\text { Carol Anderson }\end{array}$ & $\begin{array}{l}\text { Making referrals to West River from our } \\
\text { communities of Sheridan County as they comes } \\
\text { through that area on their run to Turtle Lake. }\end{array}$ \\
\hline
\end{tabular}


Transit System:

Kidder Emmons Senior Services

\begin{tabular}{|l|l|l|}
\hline $\begin{array}{c}\text { Existing Process for } \\
\text { Identifying Local Mobility } \\
\text { Needs }\end{array}$ & \multicolumn{1}{|c|}{$\begin{array}{c}\text { Process for Responding to } \\
\text { Identified Local Mobility } \\
\text { Needs }\end{array}$} & $\begin{array}{c}\text { Proposed Actions to Enhance } \\
\text { Need Identification and } \\
\text { Response Process }\end{array}$ \\
\hline Outreach & Info on transit schedule & $\begin{array}{l}\text { Gather information from Region } \\
7 \text { outreach }\end{array}$ \\
\hline Brochures - Magnets & Schedule Info. & Get more public information \\
\hline Meetings & Handing out brochures; & More involved/meetings \\
\hline informing public about transit & Informing public of transit & Get public more involved \\
\hline Word of mouth & Pubic aware of transit in county & Utilize businesses \\
\hline Advertising & Make sure public is aware of \\
& transit and aware of client needs & Utilize newspaper more \\
\hline & & \\
\hline & & \\
\hline & & \\
\hline
\end{tabular}




\begin{tabular}{|l|l|}
\hline $\begin{array}{c}\text { Identify Other Transit Providers that } \\
\text { Services are Coordinated With }\end{array}$ & \multicolumn{1}{c|}{$\begin{array}{c}\text { List Specific Coordination Initiatives that are } \\
\text { Currently in Place }\end{array}$} \\
\hline James River & Bus pick-up in Woodworth on route to Jamestown \\
\hline James River & $\begin{array}{l}\text { Riders drive to Pettibone to pick-up for route to } \\
\text { Bismarck }\end{array}$ \\
\hline & \\
\hline & \\
\hline & \\
\hline
\end{tabular}




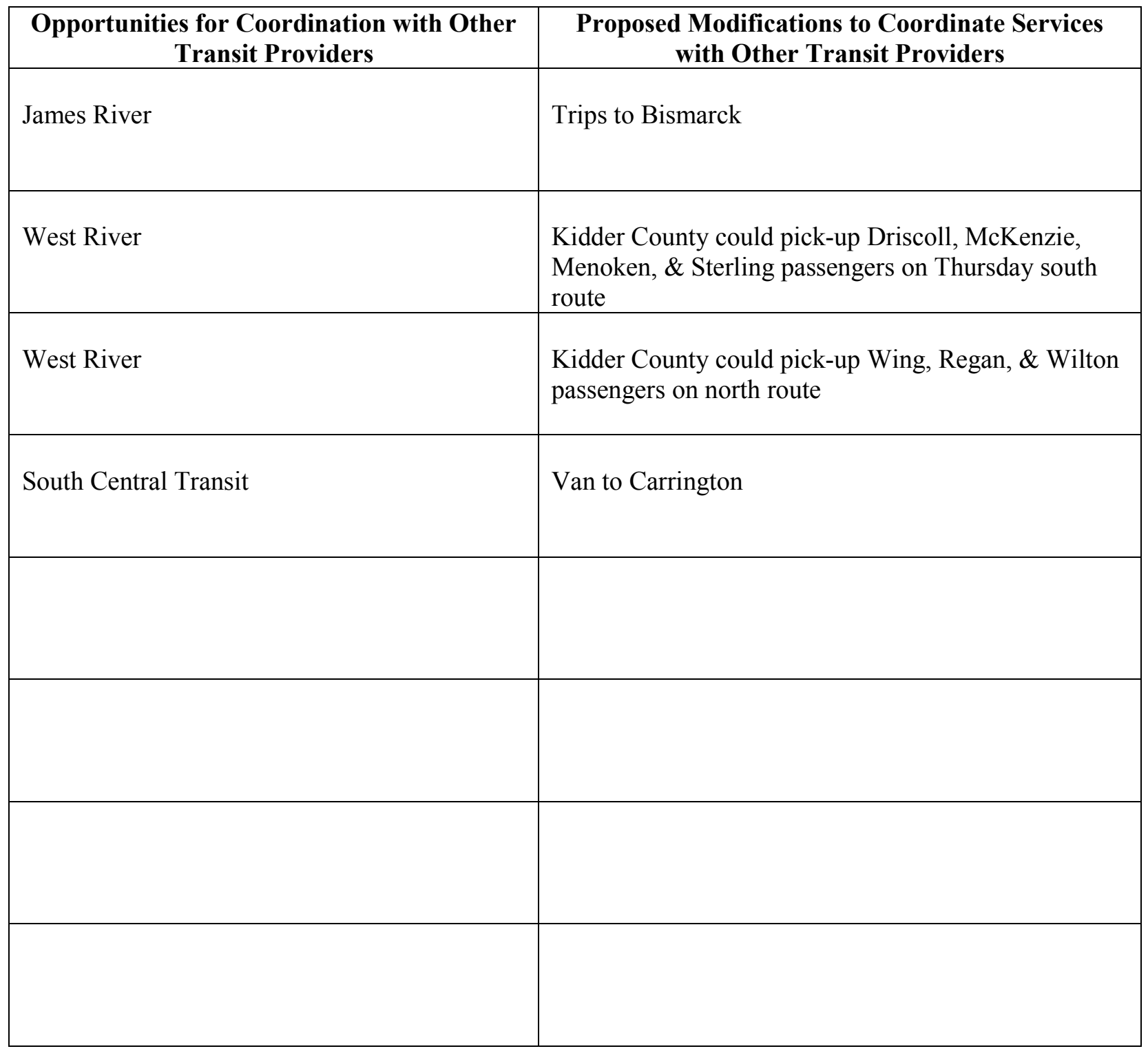


Transit System: $\quad$ Standing Rock Public Transportation

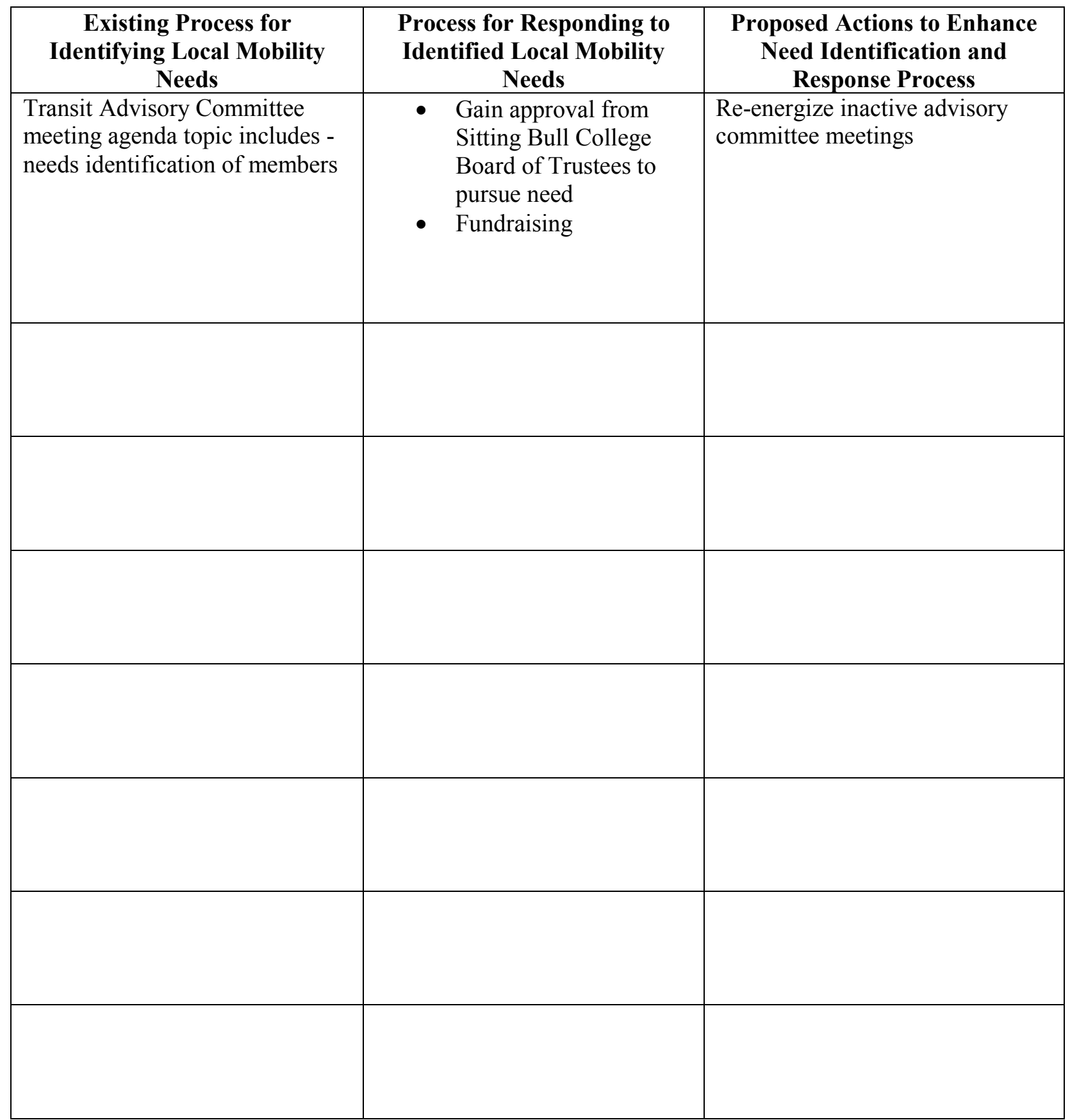




\begin{tabular}{|l|c|}
\hline \multicolumn{1}{|c|}{$\begin{array}{c}\text { Identify Other Transit Providers that } \\
\text { Services are Coordinated With }\end{array}$} & \multicolumn{1}{c|}{$\begin{array}{c}\text { List Specific Coordination Initiatives that are } \\
\text { Currently in Place }\end{array}$} \\
\hline $\begin{array}{l}\text { Rim Rock - I-94 } \\
\text { Jefferson Lines - I-90 } \\
\text { River Cities Transit (Pierre, SD) } \\
\text { Cheyenne River Transit (Eagle Butte, SD) } \\
\text { New Town Bus Lines (Minot, ND) }\end{array}$ & \\
\hline & \\
\hline & \\
\hline & \\
\hline & \\
\hline & \\
\hline
\end{tabular}




\begin{tabular}{|l|c|}
\hline $\begin{array}{c}\text { Opportunities for Coordination with Other } \\
\text { Transit Providers }\end{array}$ & $\begin{array}{c}\text { Proposed Modifications to Coordinate Services } \\
\text { with Other Transit Providers }\end{array}$ \\
\hline $\begin{array}{l}\text { Veterans Hospital trips (North \& South } \\
\text { Dakota) } \\
\text { Aberdeen, SD and North South Shuttle }\end{array}$ & \\
\hline & \\
\hline & \\
\hline & \\
\hline & \\
\hline & \\
& \\
\hline
\end{tabular}


Transit System: South Central Transit Network

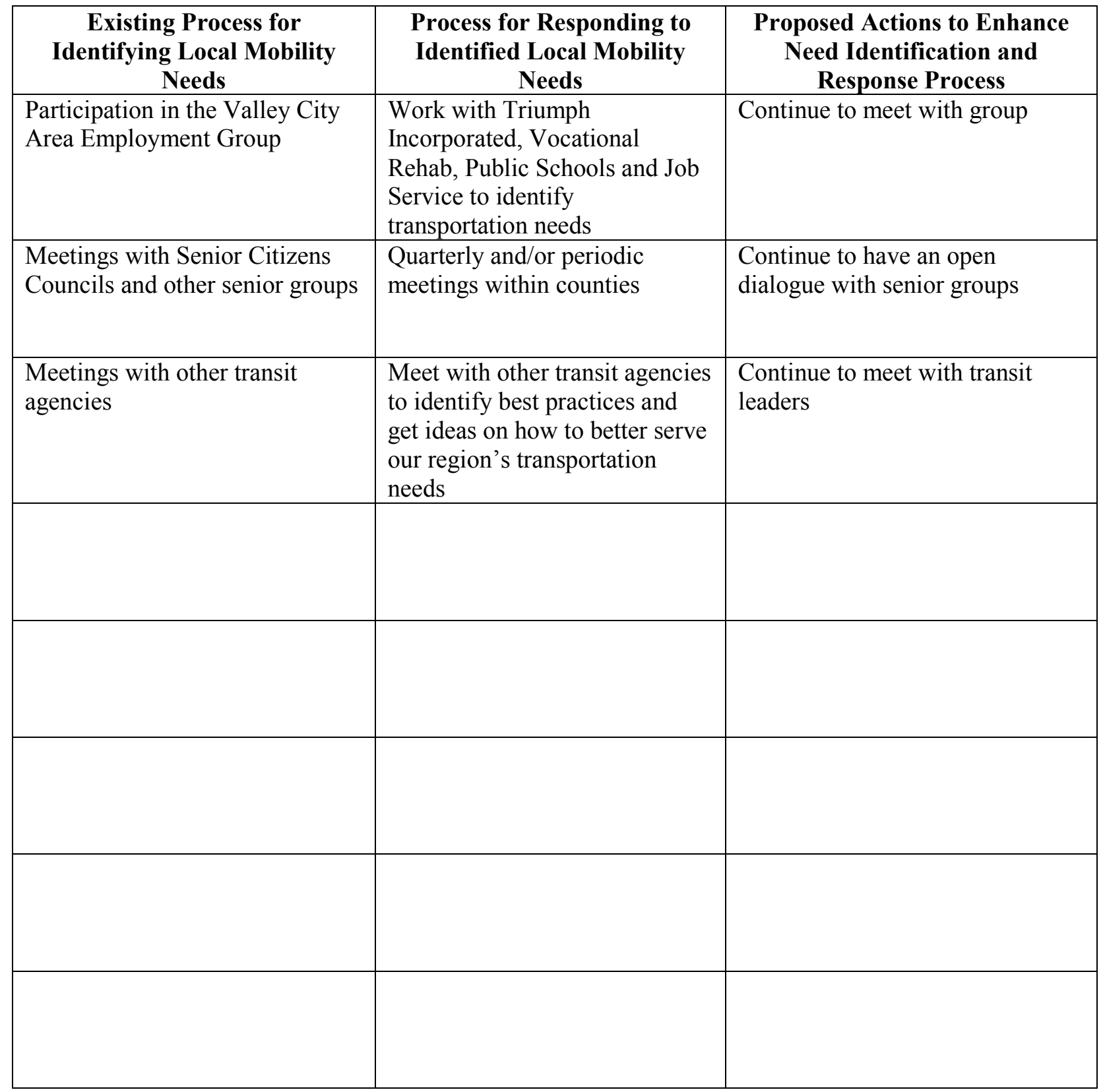




\begin{tabular}{|l|l|}
\hline \multicolumn{1}{|c|}{$\begin{array}{c}\text { Identify Other Transit Providers that } \\
\text { Services are Coordinated With }\end{array}$} & \multicolumn{1}{c|}{$\begin{array}{c}\text { List Specific Coordination Initiatives that are } \\
\text { Currently in Place }\end{array}$} \\
\hline James River Transit & $\begin{array}{l}\text { Coordination of Fargo transportation and } \\
\text { transportation within Stutsman County }\end{array}$ \\
\hline Dickey County & $\begin{array}{l}\text { Coordination of South Dakota Transportation - } \\
\text { Aberdeen }\end{array}$ \\
\hline $\begin{array}{l}\text { VA Bus - Individual Counties Veterans } \\
\text { Services }\end{array}$ & Coordination of veterans' transportation \\
\hline Rimrock Trailways & $\begin{array}{l}\text { Coordination in conjunction with Rimrock Trailways } \\
\text { bus schedule }\end{array}$ \\
\hline West River Transit & Strasburg to Beulah transportation \\
\hline Steele County Transportation & $\begin{array}{l}\text { Griggs and Steele Counties coordination of Fargo } \\
\text { transportation }\end{array}$ \\
\hline & \\
\hline
\end{tabular}




\begin{tabular}{|l|l|}
\hline \multicolumn{1}{|c|}{$\begin{array}{c}\text { Opportunities for Coordination with Other } \\
\text { Transit Providers }\end{array}$} & $\begin{array}{c}\text { Proposed Modifications to Coordinate Services } \\
\text { with Other Transit Providers }\end{array}$ \\
\hline $\begin{array}{l}\text { Foster and Griggs Counties transportation with } \\
\text { Wells, Nelson, Benson and Ramsey Counties }\end{array}$ & $\begin{array}{l}\text { Transportation to Devils Lake or Grand Forks and } \\
\text { within listed counties }\end{array}$ \\
\hline $\begin{array}{l}\text { Emmons, Logan and McIntosh Counties } \\
\text { transportation with Kidder and Burleigh } \\
\text { Counties }\end{array}$ & Transportation to Bismarck and within listed counties \\
\hline $\begin{array}{l}\text { LaMoure and Barnes Counties transportation } \\
\text { with Dickey, Ransom, Sargent, Cass and } \\
\text { Richland Counties }\end{array}$ & $\begin{array}{l}\text { Transportation to Fargo and Wahpeton and within } \\
\text { listed counties }\end{array}$ \\
\hline & \\
\hline & \\
\hline & \\
\hline
\end{tabular}


Transit System: _ West River Transit

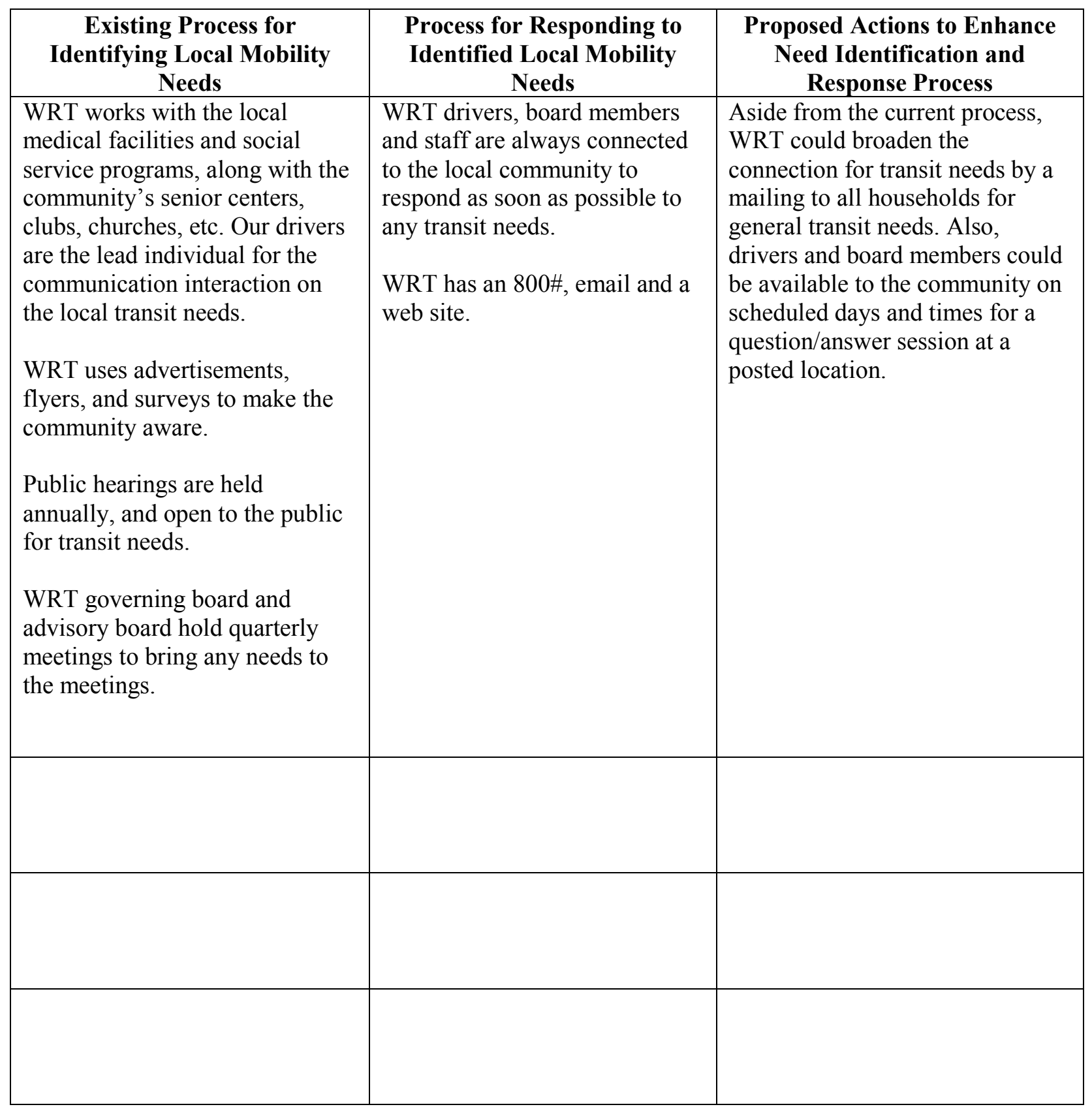




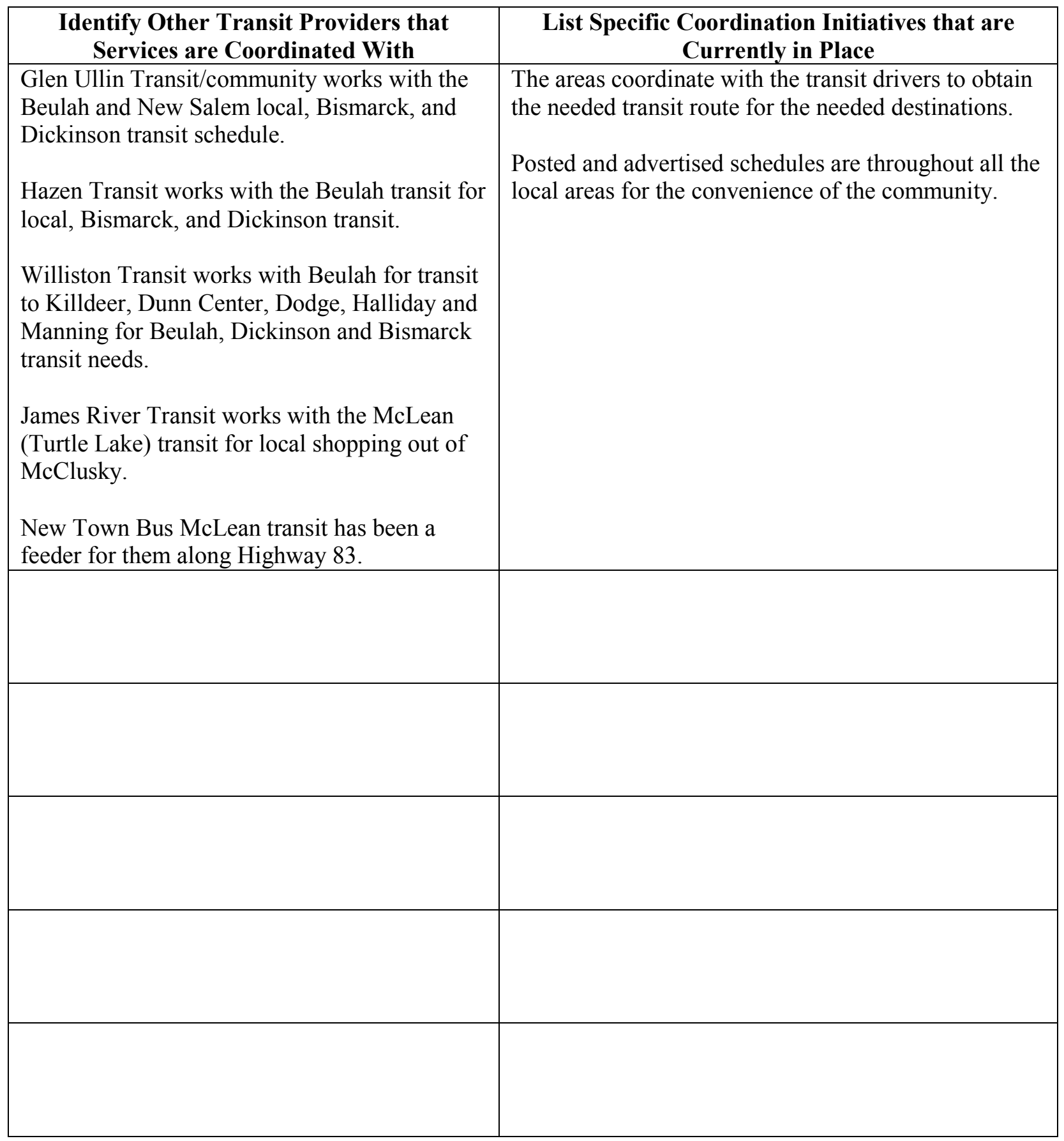




\begin{tabular}{|c|c|}
\hline $\begin{array}{c}\text { Opportunities for Coordination with Other } \\
\text { Transit Providers }\end{array}$ & $\begin{array}{l}\text { Proposed Modifications to Coordinate Services } \\
\text { with Other Transit Providers }\end{array}$ \\
\hline $\begin{array}{l}\text { Bis-Man Transit - local Bismarck, Mandan } \\
\text { transit is available for any individuals that } \\
\text { arrive from our communities on a weekly } \\
\text { schedule. } \\
\text { Elder Care Transit in Dickinson would have the } \\
\text { availability to coordinate on scheduled transit } \\
\text { days from Beulah, New Salem, Dunn and } \\
\text { Hebron to supplement local needs. } \\
\text { Kidder Emmons Transit has the availability to } \\
\text { coordinate with the McLean and the Rural } \\
\text { Burleigh Transit on a weekly schedule, for } \\
\text { local and Bismarck transit needs. } \\
\text { Mclean Transit is in the Minot area monthly } \\
\text { and could assist with Minot local needs. }\end{array}$ & $\begin{array}{l}\text { All transit agencies need to develop a schedule for } \\
\text { expanding schedules that are current and added needs. } \\
\text { Questionnaire for locals to request and answer transit } \\
\text { needs they have and would like to be able to utilize in } \\
\text { their area. } \\
\text { New schedules could be coordinated, and establish a } \\
\text { trial period of transit usage to identify the actual needs } \\
\text { the areas may develop. }\end{array}$ \\
\hline
\end{tabular}




\section{APPENDIX C: \\ TEMPLATE RIDERS' GUIDE}




\section{RIDERS' GUIDE}

\section{Tri-fold printed front and back}

Front page: graphic tied to banner from website

(Insert name of transit system) provides general public transportation for all people. You do not need to meet any qualifications or requirements to use the system.

\section{Inside and back pages}

\section{Hours of Operation}

(Insert transit hours of operation)

The office hours in (insert central office location) are Monday through Friday from (insert hours of operation) (include Saturdays and Sundays and hours if appropriate). (Insert name of transit system) is closed for New Year's Day, Easter, Memorial Day, July $4^{\text {th }}$, Labor Day, Thanksgiving and Christmas Day.

Using the transit system to travel from one single location to another single location is called a one-way ride. If you travel to a destination and require a ride home or to be taken to another location, it is called a round trip. When you schedule your ride, be sure to tell the dispatcher or driver if you are planning multiple stops, so that all of your rides are accounted for in the scheduling.

\section{Ride Reservations}

You must schedule your ride in advance. (Insert \# to call or procedure for your transit agency). The driver will arrive at your specified pickup location at the agreed-upon time and take you to your destination. Be ready to board the bus 10 minutes prior to your scheduled pickup time.

\section{Fares}

(Insert fares)

Bus fares are generally paid to the bus driver when you board the bus unless prior arrangements have been made. For more information, please contact (list contact and number). 


\section{Cancellations}

Please contact (list who to contact) as soon as you become aware of the need to cancel your ride. If you do not cancel, you may be charged for the ride. Repeated "no shows" may result in a suspension of your bus riding privileges.

\section{Pickup Window}

(Insert name of transit system) operates on a plus or minus (insert \# of minutes) minute pickup window, meaning that you should be ready to board the bus at least (insert \# of minutes) minutes prior to your scheduled pickup time. Also, you should expect the bus to arrive no later than (insert \# of minutes) minutes after your scheduled pickup time.

\section{What am I allowed to bring on the bus?}

For questions about items you can or cannot bring on the bus in addition to those listed below, contact (insert who should be contacted and how to contact them) prior to getting on the bus.

\section{Packages}

You may have as many packages as you can keep under your control while the bus is moving. Secure loose items to prevent them from rolling around. Nothing may be placed in the aisle or next to the wheelchair lift.

\section{Mobility Devices and Wheelchairs}

We have buses and vans that are accessible for people who use mobility devices. When you call to reserve your ride, please tell the dispatcher or driver if you use a mobility device such as a walker, manual or motorized wheelchair, scooter, etc., and if you will need a lift or ramp to enter the vehicle.

All mobility devices must be secured within the vehicle by the driver. Our drivers have all received training in handling mobility devices and securing them properly.

\section{Oxygen Tanks}

Portable oxygen tanks are allowed on the vehicle but must be secured by the driver. Please let the dispatcher or driver know when you schedule your ride if you will be bringing a portable oxygen tank on board. 


\section{Car Seats}

If you are bringing a small children or infants with you on the bus, you may bring a car seat for them to use. You must restrain the car seat using the seat belts provided in the vehicle. The driver will not be responsible for restraining the car seat.

\section{Strollers}

Children must be removed from strollers. Strollers must be able to be collapsed and fit between the seats of the bus or secured by the driver. Strollers may not be placed in the aisle or next to the wheelchair lift.

\section{Food and Drink}

Food and beverages are allowed on the vehicle. Beverages must be in a sealable container. Take all garbage with you when getting off the bus.

\section{Pets (not Service Animals)}

Pets are only allowed on the bus if prior arrangements have been made with the central office, dispatcher or driver. All pets must be in approved pet carriers and must fit on your lap or the seat next to you. Pet carriers are not allowed in the aisle or in the wheelchair lift area. You will be solely responsible for loading and unloading the pet carrier.

\section{Service Animals}

Service animals are permitted to accompany individuals with disabilities in vehicles and facilities operated by (Insert name of transit system). The rider may be refused transportation services if the service animal is not under the control of the person with the disability, or if it is threatening the safety of others.

\section{Cell Phones}

While the use of cell phones is permitted on the bus, we ask that passengers please be considerate of the other riders. Loud talking that disturbs other passengers may result in a driver asking the offending passenger to restrain from using their cell phone.

\section{Passenger Assistance}

(Insert name of transit system) provides door to door service for any passengers needing this assistance. Please let the dispatcher or driver know if you will require this assistance.

\section{Escorts and Personal Attendants}

Attendants traveling with passengers who are frail and require assistance, may travel at no charge. The escort must get on and off the vehicle at the same locations as the passenger. When you schedule your ride, let the dispatcher know that an escort will be accompanying you. Under some circumstances, you may be required to have a personal care attendant or escort. (Insert name of transit system) will inform you ahead of time if you need to have an escort with you in order to ride the bus. 


\section{Seat Belts}

All passengers are encouraged to wear seat belts at all times while riding in our vehicles.

\section{Closure Due to Weather or Other Emergencies}

(Insert name of transit system) makes every attempt to provide service during scheduled hours. When extreme weather conditions make travel unsafe, we reserve the right to discontinue services until conditions improve. In case of severe weather, every effort will be made to get all passengers returned to their homes as quickly as possible.

(Insert name of transit system) uses local radio stations to broadcast closures due to dangerous weather conditions or other emergencies (blizzards, flooding, etc.). Check your local stations for announcements. If you are a dialysis patient and need to get to your appointment, we recognize that this is a life sustaining necessity, and every possible effort will be made to ensure that you are able to receive your necessary treatment. (List local radio and/or TV stations)

\section{Refusal of Service}

(Insert name of transit system) has empowered its drivers to refuse service to any passenger who is intoxicated, under the influence of drugs, or may be dangerous or disruptive. Drivers also have the right to remove people from the bus who are belligerent, rude, or refuse to follow agency policies or directions. If the driver believes a passenger poses a safety or health threat to themselves or others, the driver may contact dispatch or the police for assistance. Passengers are not allowed to carry weapons on the vehicle. If a person has unreasonable personal hygiene, the agency director or transit coordinator may discuss the issue with the passenger and discuss corrective action that needs to be taken to continue riding the bus. 


\section{Complaints or Comments}

(Insert name of transit system) encourages those with concerns or complaints to contact (insert appropriate contact by title not name). Please be prepared to be as specific as possible about the concern or event. We follow up on all complaints. You may call (list telephone \#) or submit a complaint in writing to the agency director at (list agency name and address). You may also make an appointment with the director to visit in person. All comments and complaints will be handled in a timely and efficient manner.

Suggestions for improvements to our transit program are always appreciated. We encourage your comments and recommendations. If you have received superior service, we also encourage you to let us know so we can pass that information on to our employees.

\section{Prohibited Behavior}

No standing - Remain seated when the bus is moving

No smoking

No fighting, throwing things, pushing, shouting, loud behavior, or vulgar language

No firearms, weapons, gasoline or other flammables, or fireworks

No feet on the seats

Shirts and shoes are required attire

No roller-skates or rollerblades worn on the bus

\section{Lost \& Found}

Check the area around you for personal items before exiting the bus

(Insert name of transit system) is not responsible for items left on its vehicles. However, if you believe you have left something on the bus, contact the dispatcher or driver and let them know which bus you were on and where you were seated.

\section{Back page}

Bottom of page: Discrimination Statement

No one shall be denied a ride based on race, color, national origin, religion, sex, physical or mental disability, marital status, political affiliation, public assistance status, sexual orientation, military status or status as a U.S. veteran. If you believe you have been discriminated against, please contact the agency Director between the hours of (insert hours) Monday through Friday at (insert telephone \#) or by mail at (insert address). 


\section{APPENDIX D: \\ OPERATOR INPUT CONCERNING COORDINATION PROJECT AND FUTURE EFFORTS}




\section{Operator Input from 7/25/12 Quarterly Meeting}

The questions presented below were sent to the regions' transit managers prior to the meeting. Responses were garnered during a meeting of all the regions' directors. These responses were compiled and distributed to the directors to insure that they accurately reflected what was said. Directors were also invited to submit supplementary comments. Related input is also reflected in the following compilation.

1. What coordination-related changes has your system made in last three years, if any?

Kidder County Transit - Renee Price, Director

- Creating advisory committee

- Doing additional advertising

- Updated brochure including James River dispatch number

- Joined Chamber of Commerce/Betterment Club

James River Transit - Laurie McGuire, Director

- Better communication with other transit systems

- Increased awareness of other systems routes/fares

- Coordinating with South Central Transit on weekly Fargo trip

- Wells/Sheridan bus coordinating with Benson County

- Coordinating Bismarck trip with Kidder County

West River Transit - Ellen Lang, Administrative Assistant

- New brochure information

- Additional communication with cities in area

- Additional advertising in Dollar Saver and Extra shopper publications - doing very well and reaches people who do not necessarily subscribe to local newspapers

Hazen Busing - Sandy Bohrer, City Auditor

- Updated brochure information, including with West River Transit contacts

- Better communication with other agencies

- Increased awareness of other systems routes/fares

- Additional advertising: Dollar Saver and local papers

Standing Rock Public Transit - Pam Ternes, Director

- Created new riders guide using SURTC template

- Survey - $10 \%$ return rate; additional public meetings planned

- Additional advertising, primarily radio

- Updating Transit Management Plan

- Added route to Fargo, primarily for veterans

South Central Transit Network - Pat Hansen, Director

- New riders guide using SURTC template

- Increased communications with other operators via quarterly meetings

- Coordinating with James River on east/west corridor

- Coordination with Kidder County on west corridor

- New website

Dickey County Transportation - Cheryl Jongerius, Director

- Additional communications with other operators

- Added McIntosh County ride information to advertising 
- Weekly transit ad in local newspaper (free)

- Communication/coordination on Aberdeen trips

Glen Ullin Public Transportation - Kathy Boschee, Director

- Communication/cost sharing with West River Transit on trips to Bismarck and Dickinson and doubling trip options for riders

- Communications with City of Hebron

2. Besides local coordination, what changes have you observed that are attributable to the coordination project?

- Creation of websites and linking NDDOT website to providers' sites

- Updated existing websites

- Better understanding how diverse transit is/can be

- Better understanding how transit is a social asset/advantage

- Better relationship with NDDOT

- Better awareness of other transit systems and their routes/fares

- Creation of Riders Guide

- Best practices and policies samples

- Increased travel options for clients and communities

- More open communications and positive networking among agencies

3. Has the coordination project been overly burdensome to local transit operators?

- No, appreciated scheduling meetings in conjunction with senior provider meetings

- Ability to complete paperwork via e-mail very convenient

- Appreciated that operator's wishes were heard, and there were not a lot of extra meetings

- Meetings that were scheduled were constructive and productive

4. Value of quarterly meetings of regions' transit operators?

- Quarterly meetings were very valuable - sharing information and networking should continue

- Very useful and a good use of time

- Learned a lot of information about other systems

- Scheduling in conjunction with Senior Service meeting was beneficial

- SURTC and NDDOT staffs are very helpful in guiding agencies with improvement opportunities. Very valuable resources.

5. What, if any, portions of the coordination project have benefited transit operators outside the two pilot regions?

- Websites

- Rider's Guide

- Policies

- Marketing 
6. What, if any, portions of the coordination project should be pursued in other regions of the state?

- Riders guide

- Route and fare information

- Route mapping exercise

- Fare grid

- Every system should have a website

- Every system should do route/fare analysis

- NDDOT website enhancement and connection to system websites

- Statewide map/exercise showing each system's routes would be beneficial

- Continued meetings with time focused on coordination

7. What can be done to ensure that coordination-related communications and initiatives continue within the two pilot regions?

- Continue quarterly meetings with input from transit systems

- Meetings should be focused and facilitated with an agenda

- Some way of documenting results of coordination efforts needed (i.e. shared rides, increased ridership, ride opportunities, etc.)

8. What role could a regional coordinator fulfill in the future, and what services could he or she provide to local transit operators?

- Some managers voiced the opinion that a mobility manager/regional coordinator position would be a waste of money; funds are needed to meet existing needs

- Conversely, some managers felt that without some type of position working on coordination, everything that was accomplished via this process may be lost

- There are tasks that need to be done (relative to coordination and administration) that directors do not have time to do

- Research evolving issues

- Provide transportation alternatives and connections (i.e. volunteer drivers, other nontransit providers, etc.)

- Facilitate communication between systems

- Outreach to non-typical clients, business and agencies

- Recruit volunteers for alternative rides

- Policy updates

- Help establish advisory committee in agencies where they do not exist

- Assist in keeping existing committees active and viable

- Assist in cross regional coordination since position would work with numerous transit systems across the state.

- The person in this position needs experience working with public bodies and with transit

- At least one manager questioned the appropriateness of basing a mobility manager with Community Action, based on its past performance

9. How much staffing is necessary and where should staffing and funding come from to support future coordination-related efforts?

- 1-2 individuals covering different portions of state

- NDDOT administration portion of transit grants may be available at $100 \%$ to cover positions

- Need more money for service, not for mobility managers 
- Systems do not have extra money for cost share

- This position should be a state funded employee - if mandated by legislation, then they should also provide a funding source for the position.

10. Given the fact that few rural transit systems have full-time, transit-only administrators, what can be done to make productive use of the time that administrators have to devote to transit-related duties, including coordination?

- Schedule meetings in conjunction with other meetings to minimize travel time and time away from facilities

- Better/increased use of technology

- Because of new funding guidelines, NDDOT is requesting more reporting and documentation. A coordinator for our region could help complete needed information on grants, make sure all policies are in order for agencies, do some training at the agencies office, and mentor new agency directors.

- Shouldn't look at multiple service providers as a detriment; these operators have contacts and relationships due to the many services that are provided.

- The current (coordination) process has been helpful to operators and should be continued.

11. Other issues that transit administrators would like to discuss: None 


\section{Operator Comments on Draft Report}

(comments received from 3 of North Dakota's 32 transit operators)

From: Cheryl J ongerius [mailto: dcsc213@yahoo.com]

Sent: Thursday, November 15, 2012 10:21 AM

To: Mielke, J on

Cc: Carol Anderson; Pat Hansen; Laurie McGuire; Paul Benning; Stacy Hanson; Kim S. Adair; Becky Hanson

Subject: SURCT Report Comments

I decided to send my comments about the (almost final) SURTC coordination report to share with each of you.

1. SB 2223 is referenced numerous places in this document. There are phrases such as "assumed the Legislature envisioned -coordination would ultimately be expanded to cover the entire state" page vi. SB 2223 also uses the language that the DOT director shall report to the $62^{\text {nd }}$ legislative assembly (that was in 2011) the findings and recommendations of the pilot (a report was given to the legislative council) but how and when did the 2011 legislature hear about the pilots and decide to continue it? Page 2 top "It is assumed that the Legislature hoped....." Page 53 - "It is assumed that the 2009

Legislature...... would not only continue but also be expanded to other regions of the state" Page 54 "it is reasonable to assume that legislators hoped .... and that related efforts would be pursued elsewhere in the state" I am at a loss to understand how the report can draw all these conclusions about the what the legislature hoped or envisioned. It would seem to me that the legislature should be making that call about what they want for the future as for as transit regional coordination, not making an assumption.

SURTC and NDDOT transit staff response: The 2010 coordination report was presented to the Legislative Council in January 2011. That action satisfied S.B. 2223's reporting requirements. NDDOT has subsequently moved forward with related implementation.

2. Federal "coordination" mandates are referenced as a reason to have "regional coordinators". It would seem there are a variety of ways to meet the Federal coordination mandates - not just the Regional Coordinator path.

SURTC and NDDOT transit staff response: The regional coordinator approach is required by S.B. 2223 and satisfies related federal requirements. This approach was recommended in SURTC's 2010 coordination report. Addressing federal mandates via some other means could create dual and perhaps competing or conflicting approaches to coordination. NDDOT's executive management team directed the department's transit staff to create and fill two pilot regional coordinator positions prior to the 2013 legislative session, thereby satisfying the prescriptions of S.B. 2223.

3. The Budget. It is personally painful for me to read what kind of money is intended to be spent on these (up to 5) positions. It is clear in the report (in numerous places) that the Federal money that is being proposed to be used could either be used as operating money for local transit providers or for some of the Federal sources - capital money. To be directing that kind of money into 5 additional administrative jobs seems to put the priority on exactly the wrong thing. It is also disheartening (to say the least) to see the kinds of salary and benefits that are budgeted for these positions when rural transit administrators do not make these kind of salaries or benefits. 
SURTC and NDDOT transit staff response: The SAFETEA-LU money that is being used to fund the current positions cannot be used for normal operations and MAP-21 requires a related maintenance of effort. Concerning existing coordinator compensation, unreasonably low transit manager salaries and benefits do not justify low coordinator compensation. Compensation packages for local transit managers are set at the local level by local governing boards.

4. It is also clear from the report that local entities will be asked to pay the "match" for these positions in the future. This takes money away from operating and moves it to administration. It is also clear that if the local operators won't or can't come up with match, the intent of the state is just to take money off the top of the Federal allocation - again reducing what is available to local providers for operating or capital. These priorities do not seem in line with enhancing and strengthening the provision of actual transit service.

SURTC and NDDOT transit staff response: One option presented in the report is to fund the transit coordinator positions with 5311 administrative funds which require no local match. Given the increase in related MAP-21 funding, this approach would not reduce the amount of funding that 5311 operators are currently receiving.

5. Already hired Regional Coordinators - the 2 that have already been hired work for Community Action and Bis-man Transit. What does that really mean to a rural transit provider? Last I looked, I don't work for either of those organizations, nor do I receive any funding from them - so what exactly is our agencies' relationship to this new coordinator? Page 55 - bottom "newly-hired regional transit coordinators may not have a complete skill set necessary to fulfill all the duties..........some of these skill sets will be developed via... subsequent job exposures, mentoring....." Is it perceived that local transit operators will be providing this mentoring?

SURTC and NDDOT transit staff response: Local transit operators and NDDOT's transit staff work together to provide effective and efficient transit services. Regional transit coordinators are funded through NDDOT to work towards achieving the same goals. A corresponding team effort, by all parties, is needed to enhance coordination and personal mobility.

6. I really believe the paragraph (section 3.2.4) on pages 41-42 that I objected to in the first draft and we discussed at our October meeting still does not accurately characterize what we as local transit providers have said. What the report now says:

"During discussions at the July $25^{\text {th }}$ meeting, a few operators initially voiced the opinion that regional transit coordinators were unnecessary" What I believe it really should say is "During discussions.......HALF of the operators voiced the opinion that regional operators are unnecessary" The word "initially" looks like we have changed our mind. The October meeting discussion when 4 operators verbally stated they felt Regional Coordinators were NOT necessary speaks to the fact that the feeling was "no" in July and it is still no.

At the October meeting there were 4 "nos", 1 yes, 1 said nothing and 2 absent. For the majority of this report, 8 operators are discussed as being part of the pilot (in at least one place Bis-Man gets counted as a $9^{\text {th }}$ operator). Since the majority of the report uses the number 8 , I think that is the number that should be counted as "operators" who have an opinion to voice as a result of pilot coordination project.

The second part of this paragraph at the top of page 42 also slants (in my opinion) the input of the operators. After we had the discussion about "do we need coordinators (NO)," then the next question presented was - well since we already have coordinators what can they be doing to help you. I do NOT think at any point did "most of the participating operators agree that some level of regional staffing would be beneficial". 
SURTC and NDDOT transit staff response: Several managers at the cited meetings indicated that the current coordination project had produced positive results. They also indicated that further related efforts would not occur without some kind of supervision and assistance. The respondent, in this case, apparently believes that no form of regional coordination staffing is needed. There is obviously a spectrum of available opinions, but state and federal coordination mandates must still be addressed.

Some corresponding modifications were made in the report's language to more accurately reflect related discussions.

These are my comments.

Cheryl Jongerius

Dickey County Transportation

Dickey County Senior Citizens 
From: West River Transit [mailto:westriver.bisman@midconetwork.com]

Sent: Thursday, November 15, 2012 2:53 PM

To: Mielke, Jon; Cheryl J ongerious

Cc: Pat Hansen; Laurie McGuire; Paul Benning; Stacy Hanson; Kim S. Adair; Becky Hanson

Subject: Re: SURCT Report Comments

Hello everyone, I agree with many of the points Cheryl has stated in her email.

Several times, items were mentioned to SURTC, but they have not been corrected in the report.

Carol Anderson, West River Transit Director 
From: West River Transit [mailto:westriver.bisman@midconetwork.com]

Sent: Thursday, November 15, 2012 1:36 PM

To: Mielke, J on

Subject: Re: Transit Coordination - All Chapters

Thanks Jon!

Carol Anderson

From: Mielke, Jon

Sent: Thursday, November 15, 2012 1:26 PM

To: West River Transit

Cc: Benning, Paul M. ; Hanson, Stacey M. ; kadair@nd.gov ; Hanson, Becky R. ; Wright, Carol ; Anderson, Keven

Subject: RE: Transit Coordination - All Chapters

Carol:

Thanks for sharing your concerns. Numerous changes were made based on input that was received from various directors.

Other changes may be made based on additional input that has been received since we sent out the latest request on Nov. 1.

Jon

From: West River Transit [mailto: westriver.bisman@midconetwork.com]

Sent: Thursday, November 15, 2012 12:17 PM

To: Mielke, J on

Subject: Re: Transit Coordination - All Chapters

Jon, sorry I didn't get to this to you sooner, really felt it wasn't going to matter much, but I still am wondering why the input from operators was never corrected in the final draft? This is a soar spot with some of the directors and others that have been informed over the past months, it would have been good to voice their full opinion. Just my thoughts only!

Carol Anderson 
RE: Implementation Options for transit coordination services.

Some of my concerns/comments about the proposed SURTC Transit Coordination in ND Pilot Regions. As a transit provider in North Dakota I believe that the results of this study will affect the whole state and should therefore be addressed by the providers statewide. I have a number of concerns that I believe would be duplicating everything we are trying to do in the past few years and using funds to provide numerous regional coordinators would be detrimental to all transit budgets.

1. Adding another layer of an administrator and staff to a number of proposed regions is not cost effective. Doing a service we are already trying to coordinate with other projects should be left to those who have a direct affect to the implementation of such services and committees involved.

SURTC and NDDOT transit staff response: While the goal has always been to have transit providers coordinate with other providers as well as human service organizations, schools, businesses, and other entities, there is significant opportunity for further coordination. While transit providers are well-intentioned, many do not have the time to aggressively pursue increased coordination. Regional transit coordinators will be responsible for addressing duplication of services and implementing new coordination efforts. Efficiency and increased personal mobility should be the result. It is also important to note that regional coordinators are not another layer of administration; related positions are service providers and facilitators, and not intermediaries. Transit Providers will still direct lines of communication with NDDOT's transit staff.

2. By developing coordination plan now through this special legislative project will provide the necessary direction we need to provide cost effective transportation but at the same time spending hard to find federal and local funds for match, yet subtracting from the dollars available to the local agencies for operations. It creates another costly project above and beyond our system already in place between the DOT and transit projects.

SURTC and NDDOT transit staff response: Senate Bill No. 2223 and resulting coordination efforts provided needed impetus to enhance coordination across the state. The study has laid out a number of options for funding related coordinator positions. Given projected increases in both federal and state aid for transit, it is doubtful that implementation will result in funding reductions to support local operations.

3. Coordination plans that were discussed at various meetings can be achieved in their regions by the committees and staff personnel that are already in place. We don't need another layer explaining what we already know or can provide.

SURTC and NDDOT transit staff response: Most local transit managers oversee a wide variety of services which leaves little time to aggressively pursue increased coordination with other transit services programs, human service organizations, schools, businesses, and other entities. The current project resulted in increased coordination that simply would not have taken place without related assistance.

4. Guidance from the ND DOT transit division can be done for all the projects through state wide meetings like we are doing at this time on a limited basis.

SURTC and NDDOT transit staff response: NDDOT's transit staff intends to continue to hold quarterly meetings with all of the state's transit providers. The pilot regions' operators agreed that regional meetings held in conjunction with state-wide meetings were beneficial and should 
be continued. Regional coordinators will be responsible for establishing related agendas, conducting the meetings, and pursuing related directives.

5. Federal Transit Administration and the NDDOT are watching us to help prevent duplication of services and show financial accountability for the valuable Federal, State and Local dollars. At this time we are doing more with less funding. Doing less with more funding would not work. Adding a $\$ 280,000$ bill on a yearly basis will be hard to swallow. Directors and staff already at or below average for wages and benefits, paying someone $\$ 70,000$ plus to do what we are already trying to achieve doesn't make a lot of sense.

SURTC and NDDOT transit staff response: Improved coordination should help provide more cost-effective services. The proposed approach satisfies state and federal coordination mandates. As the study points out, related results may eventually be achievable with fewer coordinators and at a lower cost. Concerning coordinator compensation, unreasonably low transit manager salaries and benefits do not justify low coordinator compensation. Compensation packages for local transit managers are set at the local level by local governing boards.

6. I do see some valuable information in the report, but I also see it as a script of what a committee envisioned that would work to reach an outcome to match.

SURTC and NDDOT transit staff response: The study report and its recommendations are in direct response to directives prescribed by the 2009 Legislature. Efforts were made to provide work products that also benefit transit services outside the pilot regions.

I believe working with a statewide coordinator towards mobility management can facilitate the necessary coordination, expansion, regionalization changes by working with the transit projects.

Darrell Francis

Project Director, Souris Basin Transportation 


\section{APPENDIX E: \\ SERVICE RELIABILITY GUIDELINES AND TEMPLATE POLICY}




\section{NDDOT Guidelines on Service Reliability}

NDDOT requires that transit operators develop standards and related internal policies regarding acceptable performance for scheduled vs. actual passenger pick-up times and decision making regarding the cancellation of long-distance trips due to low rider numbers, inclement weather, or vehicle breakdowns, and the recording and reporting of related cancellations.

\section{On-time performance}

Transit operators must establish a policy regarding acceptable scheduled vs. actual passenger pick-up times. This policy should:

- Identify if passengers must be ready prior to scheduled pick-up times and, if so, how much in advance

- State what is acceptable in terms of scheduled pick-up times vs. the actual arrival of the vehicle

- Indicate how long a vehicle will wait, beyond the scheduled pick-up time, for a rider to board the vehicle

- Identify what penalties, if any, will apply to no-show riders

- Provide that drivers must keep and submit a log which records scheduled pick-up times, actual pick-up times, and no-show riders

- Indicate means by which related rules will be communicated to riders and potential riders

Related policies, rules, and records must be available for review upon request by the North Dakota Department of Transportation.

\section{Service cancellations - inadequate number of riders}

Transit operators must establish a policy regarding the cancellation of scheduled trips due to inadequate rider numbers. This policy should identify:

- When scheduled trips will be cancelled due to inadequate rider numbers

- Who is empowered to make related decisions (drivers, directors, etc.)

- How scheduled riders will be notified

- Means by which related rules will be communicated to riders and potential riders

Related policies, rules, and cancellation records must be available for review upon request by the North Dakota Department of Transportation.

\section{Service cancellations - inclement weather or vehicle breakdowns}

Transit operators must establish a policy regarding the cancellation of service trips due to inclement weather, vehicle breakdowns, or other situations. This policy should identify:

- When scheduled trips will be cancelled due to inclement weather, vehicle breakdowns, etc.

- Who is empowered to make related decisions (drivers, directors, etc.)

- How scheduled riders and other potential users will be notified

- Means by which related rules will be communicated to riders and potential riders

Related policies, rules, and cancellation records must be available for review upon request by the North Dakota Department of Transportation. 


\section{Template}

\section{Service Reliability Policy}

The following standards and rules are adopted to govern scheduled vs. actual passenger pick-up times and the cancellation of scheduled services.

\section{Scheduled vs. actual pick-up times}

Desired pick-up times will be established when a passenger requests service. An acceptable pick-up time is considered to be any time from (insert acceptable standard, such as: 10 minutes prior to until 10 minutes after the scheduled time). Passengers are expected to board the vehicle within (insert acceptable standard, such as: five minutes of its arrival). Thereafter, the vehicle will leave and the rider will be considered delinquent. A rider that is delinquent more than (insert standard, such as: twice during a 30-day period will not be eligible to request service for the following thirty days).

Drivers will maintain a log which records desired pick-up times, vehicle arrival times, passenger boarding times, and any related delinquencies. Related records will be maintained by the central office and made available for review upon request by the North Dakota Department of Transportation.

\section{Service cancellations - inadequate number of riders}

Scheduled intercity trips will be cancelled unless at least passengers have made prior arrangements for related transportation. Decisions regarding related cancellations may be made by director, etc.). (identify person/official empowered to make related decisions - driver,

Persons scheduled to travel on cancelled trips shall be notified immediately, by phone. Cancellations must be reported immediately to the central office and related records will be maintained and made available for review upon request by the North Dakota Department of Transportation.

\section{Service cancellations - inclement weather or vehicle breakdowns}

Scheduled services may be cancelled due to occurrences such as inclement weather, vehicle breakdown, etc. Decisions regarding related cancellations may be made by person/official empowered to make related decisions - driver, director, etc.). (identify

Persons scheduled to travel on cancelled trips shall be notified immediately, by phone. If cancellations involve services that do not require prior reservations, public notice will be provided by (identify means by which public notice will be provided - radio announcements, etc.). Cancellations must be reported immediately to the central office and related records will be maintained and made available for review upon request by the North Dakota Department of Transportation. 


\section{APPENDIX F: \\ GUIDELINES ON SHARED TRANSIT VEHICLES}




\section{NDDOT Guidelines on Shared Transit Vehicles}

Situations may arise where a transit operator is willing to loan a vehicle to another operator. These occurrences may involve vehicle breakdowns, scheduled maintenance, etc. Being able to borrow a vehicle may enhance service reliability and overall operating efficiency and effectiveness.

It may be advisable for the loaning and the borrowing entities to execute a corresponding written lease to govern matters such as the period of use, permissible uses, associated costs, insurance requirements, etc. Such an agreement might also address issues such as required qualifications of the borrower's drivers. Sample agreements are available from the Department's Transit Division.

Absent any related provisions and actions, the loaning entity should be aware that its insurance coverage may remain in place to cover the vehicle, even though it is being operated by another service provider. If an accident occurs while the vehicle is being operated by another service provider, insurance coverage may come via the policy of the vehicle's owner and not from the policy of the borrower. Any related increase in insurance premiums would also be borne by the vehicle's owner.

If the lending operator is not willing to accept the related exposure, the governing lease agreement should require that the borrowing operator provided liability and physical property damage insurance coverage on the vehicle. This insurance requirement should be addressed in the corresponding lease agreement and should be available by contacting the borrowing operator's insurance agent.

These guidelines are not meant to dissuade the practice of loaning/borrowing vehicles. Such practices should, however, be undertaken with full knowledge of related risks and responsibilities. 